\title{
The Cambrian trilobites of Jordan - taxonomy, systematic and stratigraphic significance
}

\author{
OLAF ELICKI ${ }^{1}$ AND GERD GEYER ${ }^{2}$ \\ ${ }^{1}$ Geological Institute, TU Bergakademie Freiberg, Bernhard-von-Cotta-Straße 2, 09599 Freiberg, Germany. \\ E-mailelicki@geo.tu-freiberg.de \\ ${ }^{2}$ Institut für Geographie und Geologie, Lehrstuhl für Geodynamik und Geomaterialforschung, Bayerische \\ Julius-Maximilians-Universität Würzburg, Am Hubland, 97074 Würzburg, Germany; and Department of \\ Earth Sciences (Palaeobiology), Uppsala University, Villavägen 16, 75236 Uppsala, Sweden. \\ E-mail: gerd.geyer@uni-wuerzburg.de
}

\begin{abstract}
:
Elicki, O. and Geyer, G. 2013. The Cambrian trilobites of Jordan - taxonomy, systematic and stratigraphic significance. Acta Geologica Polonica, 63 (1), 1-56. Warszawa.

Marine carbonates and siliciclastic rocks of the Burj Formation in Jordan include paucispecific trilobite associations of the (traditional) Lower-Middle Cambrian boundary interval. Comprehensive new material of these trilobites allows a review of their taxonomy and systematic positions as well as a refined morphological description and a reconsideration of previous interpretations of their stratigraphic position and thus the correlation of the fossiliferous beds. In addition to the classic species Kingaspis campbelli (King, 1923) and Redlichops blanckenhorni Richter and Richter, 1941, Timnaella? orientalis (Picard, 1942) and Hesa problematica Richter and Richter, 1941, the discussed trilobites include Issalia gen. nov. with Issalia scutalis gen. nov., sp. nov., Tayanaspis gen. nov. with Tayanaspis bulbosus gen. nov., sp. nov., Uhaymiria gen. nov. with Uhaymiria glabra gen. nov., sp. nov., Cambrunicornia? jafnaensis sp. nov., Myopsolenites palmeri (Parnes, 1971), M. hyperion sp. nov., and Enixus cf. antiquus (Chernysheva, 1956). Myopsolenites boutiouiti Geyer and Landing, 2004 is now regarded as a junior synonym of Myopsolenites altus (Liñán and Gozalo, 1986). A detailed discussion of the correlation with a focus on global aspects provides clues for the utility of potential index fossils for the global Cambrian Series 3 and Stage 5 .
\end{abstract}

Key words: Cambrian; Trilobita; Stratigraphy; Global correlation; Dead Sea; Jordan; Israel; Spain; Morocco; Poland; South China; Siberia.

\section{INTRODUCTION}

Cambrian trilobites from Jordan have been known since the early years of the twentieth century, when the German geologist Max Blanckenhorn (1861-1947) discovered a number of specimens near the Dead Sea in 1908. He also reinterpreted trilobite remains sampled by E. Hull near the end of the nineteenth century close to the southern tip of the Dead Sea. A limited number of studies, such as those by Blanckenhorn (1910), Diene- mann (1915), Richter and Richter (1941), Parnes (1971) and Rushton and Powell (1998), provided an overview of the oligospecific faunal composition and the obviously small stratigraphic window in which the known species occurred. However, most of the earlier studies suffered from a limited amount of material and incomplete knowledge on the fine-scale stratigraphy and lateral facies changes in the region. This led to difficulties in understanding the ontogenetic variation and precise systematic position of the taxa as well as a stratigraphic 
assignment and correlation into other areas. Such correlations were mostly biased and, in addition, neglected the context of facies architecture and continental geotectonic evolution.

This study is based on copious additional material which gives a more complete portrait of the species and suggests modifications of the taxonomy and stratigraphic position. Nevertheless, new species and informally described additional forms suggest that the preservational window provides us merely with an imperfect glance at the biota during this interval in the region.

Spelling of geographic and stratigraphic Arabic local terms used in this paper is adopted from the 1: 50,000 geological map sheets. It should be noted that syntax varies among the different maps and their explanations because of the lack of a transliteration standard.

Figured specimens are housed in the collection of the Geological Institute of the TU Bergakademie Freiberg under collection number FG-602.

\section{LOCALITIES}

The material described herein has been collected during several field seasons over the last decade by one of us (OE) and his working group. Additional material was collected by GG but is not used for the documentation. For the first time, trilobites from the southern Dead Sea area and from northern Wadi Araba were sampled in situ from the bedrock so that their stratigraphic position within the succession is fixed. All former trilobite finds came either from only a single stratigraphic horizon of the Wadi Zerqa Ma'in section, northern Dead Sea shore, or from allochthonous material from the valleys at the southern margin of the Dead Sea. The material described in this study comes from four localities and sections (Text-fig. 1):

1. Wadi Zerqa Ma' in ("1" in Text-fig. 1, "B" in Text-fig. 2 left and Text-fig. 2 right, Text-fig. 3)

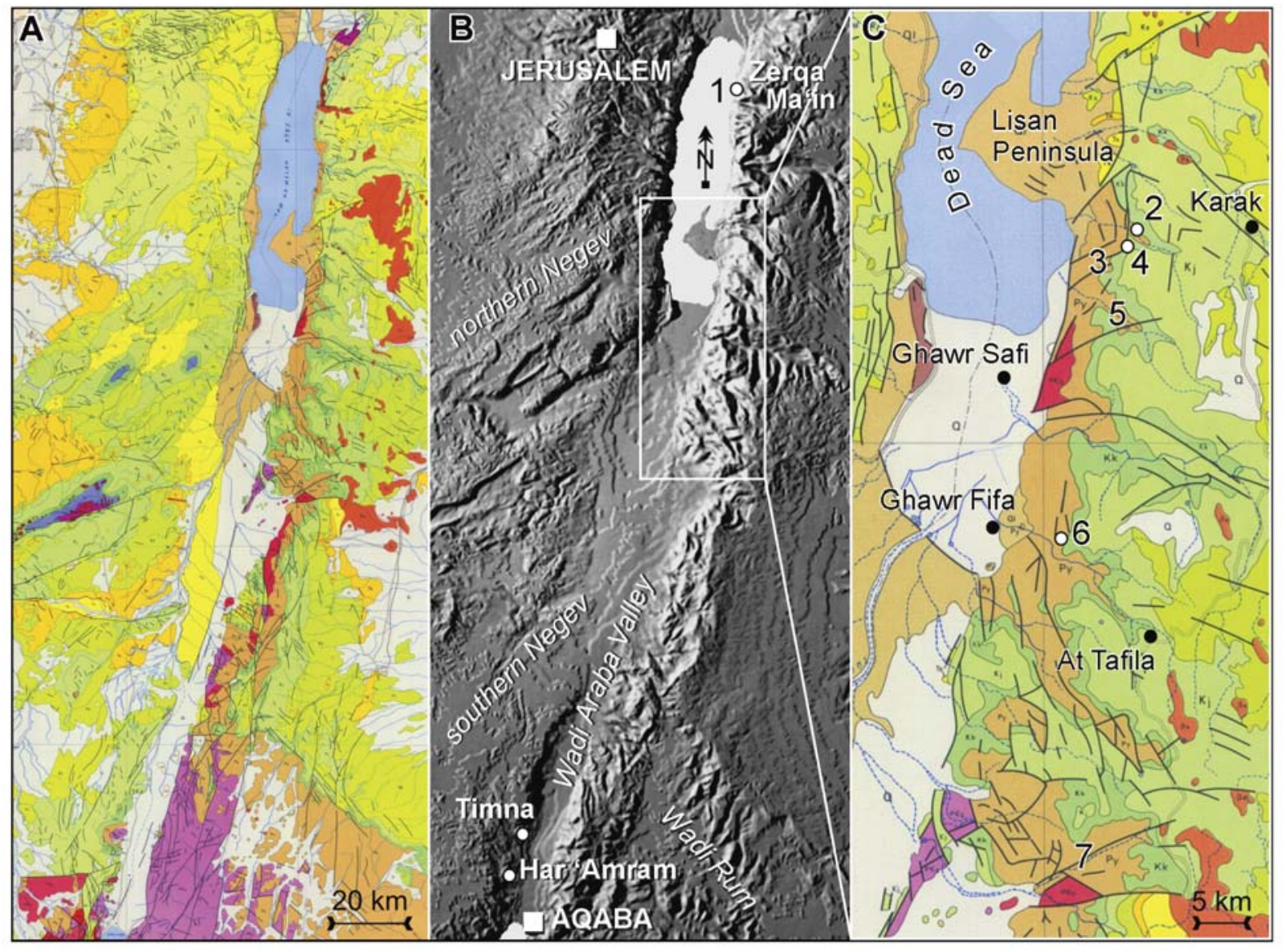

Text-fig. 1. Simplified geological map of the study area (A), satellite picture of the same area (B), and close-up of the geological map with fossil localities and large valleys mentioned in the text (C). 1 - north of mouth of Wadi Zerqa Ma' in, 2 - Wadi Issal, 3 - Wadi At Tayan, 4 - Wadi Uhaymir, 5 - Wadi Numayri, 6 - Wadi Umm Jafna, 7 - Wadi Dana. Colour code: deep red - Precambrian metasedimentary rocks (PC3); light magenta - Precambrian magmatic rocks (PE2); deep brown - Lower Palaeozoic sedimentary rocks (Py); dark magenta - Triassic; blue - Jurassic; light and dark green - Cretaceous (Kk, Kj); light red - Tertiary basaltic rocks ( $\beta 4)$; light and dark yellow - Eocene sedimentary rocks (T); light brown - Pleistocene (Q). Modified from the Geological Map of Israel $1: 500,000$ (Geological Survey of Israel, 1979) 
Northeastern shore of the Dead Sea, near the mouth of Wadi Zerqa Ma'in; 31³7'56” N, 35³4’26” E.

The classic Cambrian locality of the northeastern Dead Sea is located about $1 \mathrm{~km}$ north of the mouth of Wadi Zerqa Ma'in and exposes an approximately $80 \mathrm{~m}$ thick succession. The incomplete succession has been reinvestigated and described in detail by Shinaq and Elicki (2007). It consists of seven lithostratigraphic units, which represent the higher part of the Burj Formation, followed by strata of the Umm Ishrin Formation. The marine Burj Formation shows four shallow marine to marginal marine sandstone and minor siltstone units (partly with Cruziana ichnofossil assemblages) subdivided by three levels of shallow subtidal carbonates, each of them only a few metres thick. Trilobites of this locality come mainly from the lowermost of the exposed carbonate units. Kingaspis campbelli and Enixus cf. antiquus come from two separate bioturbated limestones of the lowest carbonate interval sensu Shinaq and Elicki (2007). Enixus cf. antiquus occurs sporadically in a fossil-bearing, distinctly bioturbated part at the top of a cross-bedded oolite. Kingaspis campbelli occurs in huge numbers in a bioturbated bioclastic grainstone to rudstone facies about one metre above the massive oolite (Shinaq and Elicki 2007). The siliciclastic heterolithic unit on top of this carbonate level is the type locality and stratum of Cruziana salomonis (Seilacher 1990) and contains abundant specimens of this trace fossil. About $43 \mathrm{~m}$ upsection (third and youngest carbonate interval sensu Shinaq and Elicki 2007), cranidia of Kingaspis campbelli were found in carbonates of a thinly bedded alternation of sandstone and ooid-bearing bioclastic grainstone. The second carbonate interval in between the two above-mentioned carbonate levels also contains trilobite remains, which are seen in thin sections, but no specimens could be cracked out from this level.

2. Wadi Issal ("2" in Text-fig. 1, "C" in Text-fig. 2) Southeastern Dead Sea area; $31^{\circ} 11^{\prime} 22^{\prime \prime}$ N, 35³3'08” E.

Trilobite material from the southeastern Dead Sea area comes from Wadi Issal and Wadi Uhaymir (Text-fig. 1). Only the upper part of the Burj Formation is exposed at Wadi Issal. The trilobite remains [Issalia scutalis gen. nov., sp. nov., Myopsolenites palmeri (Parnes, 1971)] come from the basal beds of the Hanneh Member. Cranidia and other remains are generally disarticulated and occur in sandstone horizons of shallow marine origin.

3. Wadi Uhaymir ("4" in Text-fig. 1, "A" in Text-fig. 2, Text-fig. 4)

Southeastern Dead Sea area; 319'11”N, 35³3’37” E.
At Wadi Uhaymir ('Wadi Tayan locality' sensu Elicki et al. 2002; see below), many trilobite finds come from a distinct carbonate level within the Numayri Member, about $12.5 \mathrm{~m}$ below the transition to the overlying Hanneh Member. The most prolific fossil horizon is an approximately $10 \mathrm{~cm}$ thick hash layer, which overlies an alternation of fine-grained limestone beds and marlstones (each a few centimetres thick). The hash layer is a bioturbated bioclastic floatstone with a sharp base. The trilobites [Timnaella? cf. orientalis (Picard, 1942), Tayanaspis bulbosus gen. nov., sp. nov., Uhaymiria glabra gen. nov., sp. nov., Myopsolenites hyperion sp. nov., Myopsolenites palmeri (Parnes, 1971), genus and species undeterminate 1 , genus and species undeterminate 2] occur mostly as disarticulated sclerites and are accompanied by common cone-in-cone nested monospecific hyolith assemblages (Hyolithes kingi Richter and Richter, 1941) and some brachiopods. The bioclasts are sporadically strongly current-orientated in small erosional channels (Shinaq and Elicki 2007; OE, unpubl. data). Interestingly, various ontogenetic stages occur among the large number of trilobite specimens. Larger carapaces, which occur quite rarely, functioned as a shelter and have capped smaller fossil remains, indicating significant runoff after high-energy deposition of this stratum. Upsection, the hash layer changes into an oncoid limestone with abundant brachiopods (nearly exclusively Trematosia). The depositional environment of this part of the Burj Formation at Wadi Uhaymir has been interpreted by Elicki et al. (2002) as a shallow marine setting with interfingering of lagoonal sediments and open-marine oolite shoal facies affected by occasional storm events.

4. Wadi Umm Jafna (" 6 " in Text-fig. 1, "A" in Textfig. 2)

Ghawr Fifa area of the northeastern Wadi Araba; $30^{\circ} 56^{\prime} 39^{\prime \prime} \mathrm{N}, 35^{\circ} 29^{\prime} 58^{\prime \prime}$ E.

The trilobite specimens from the Wadi Umm Jafna section (Cambrunicornia? jafnaensis sp. nov. and incomplete sclerites of two undeterminable species) come from bioclastic wackestones to floatstones with intraclasts of the Numayri Member, which occur about $15 \mathrm{~m}$ below the transition into the overlying Hanneh Member. The fossiliferous bioclastic beds are a few centimetres thick and intercalated between platy limestones. The two lithotypes alternate repeatedly over a vertical distance of several metres. Such a depositional facies is similar to that observed in the Wadi Uhaymir section in an interval 16 to $20 \mathrm{~m}$ below the trilobite hash layer. 

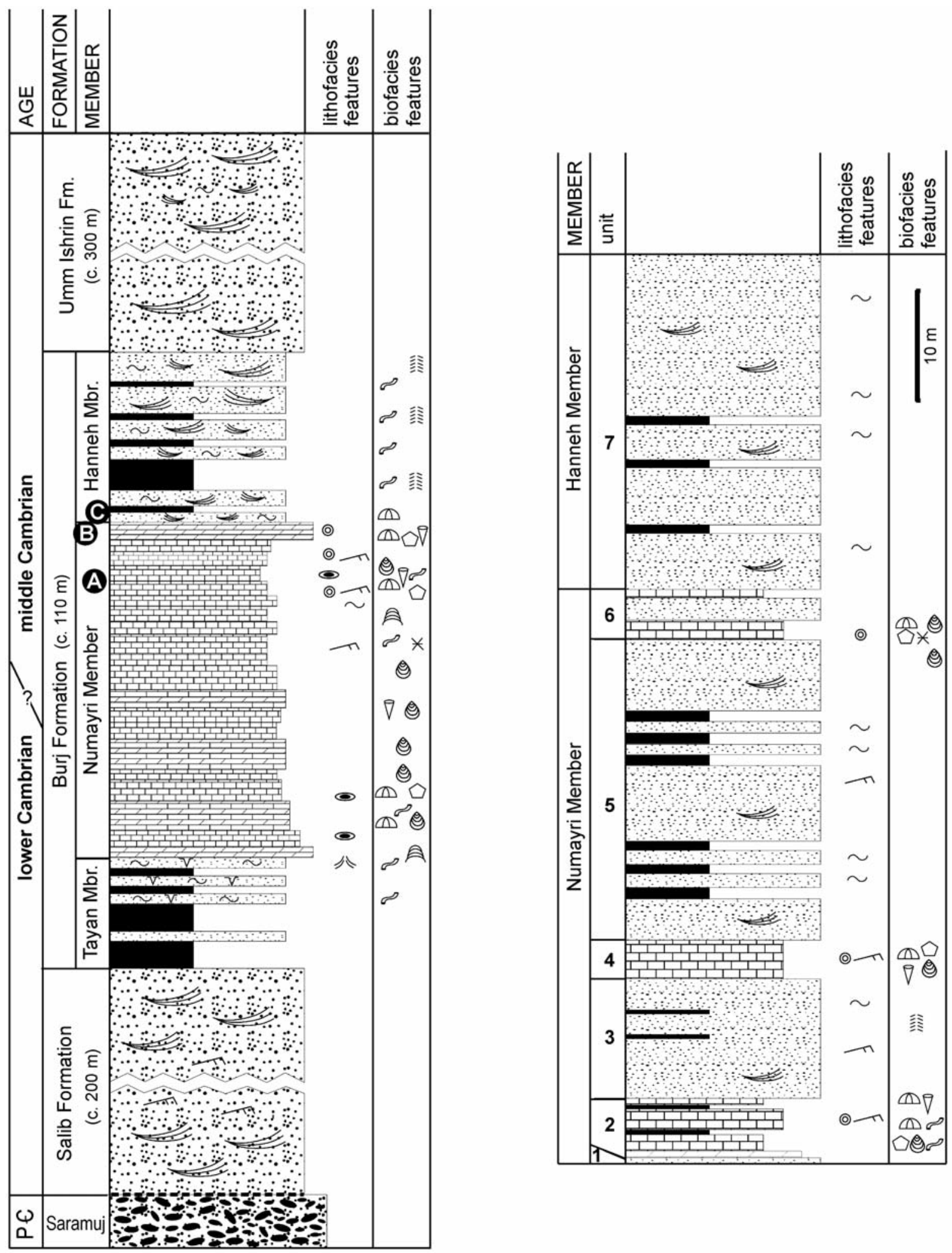

Text-fig. 2. Left: Simplified stratigraphic column of the Cambrian succession in the Dead Sea area of Jordan, with stratigraphic levels with trilobites described herein: A - Wadi Umm Jafna and Wadi Uhaymir; B - Wadi Zerqa Ma'in; C - Wadi Issal. PE - Proterozoic (Ediacaran). Data based on Powell (1989), Elicki (2007), Shinaq and Elicki (2007), and our own observations. Right: Simplified stratigraphic column of the Wadi Zerqa Ma'in section (modified from Shinaq and Elicki, 2007). For detailed description and discussion of the boundary between Numayri and Hanneh members see Shinaq and Elicki (2007) 
Wadi Issal, Wadi Uhaymir and Wadi Umm Jafna are newly discovered fossil localities. The Wadi Uhaymir section is very close to an offshoot from Wadi At Tayan, leading Elicki et al. (2002) in describing sedimentary facies types from this locality to term it the 'Wadi Tayan locality'. Rushton and Powell (1998) assumed Wadi At Tayan as being more-or-less synonymous with Wadi Rimeileh, an area from where King (1923) reported trilobite remains of 'a distinctly Asaphid type' [= Myopsolenites palmeri (Parnes, 1971)] from green micaceous siltstones to claystones. King (1923) located Wadi Rimeileh 'about $1.6 \mathrm{~km}$ south of Wadi Issal'. As already noted by Elicki (2007), the litho- and biofacies characteristics of King's samples from Wadi Rimeileh are identical to those of the Hanneh Member of the nearby Wadi Issal locality. Because of this obvious accordance, a distinctly more southerly position of Wadi

\begin{tabular}{|c|c|}
\hline 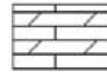 & dolomitic limestone \\
\hline וביבד & limestone \\
\hline$r^{2}$ & dolomite \\
\hline & siltstone and claystone \\
\hline$\because \because \because \because$ & medium- and coarse-grained sandstone \\
\hline $\begin{array}{l}\text { beris } \\
\text { hysis }\end{array}$ & conglomerate \\
\hline-- & unconformity \\
\hline$\rightarrow$ & planar cross-bedding \\
\hline$\ldots$ & trough cross-bedding \\
\hline$\sim$ & ripple cross-bedding \\
\hline$\checkmark$ & desiccation cracks \\
\hline 公 & tepee structures \\
\hline (-) & ooids \\
\hline 0 & oncoids \\
\hline$\infty$ & trace fossils (undifferentiated \& bioturbation) \\
\hline 韭 & arthropod trace fossils \\
\hline$\nabla$ & hyolites \\
\hline$\Delta$ & echinoderms \\
\hline es & brachiopods \\
\hline$\infty$ & trilobites \\
\hline 目 & stromatolites \\
\hline$*$ & sponge spicules \\
\hline
\end{tabular}

At Tayan (about $5 \mathrm{~km}$ south of Wadi Issal), and the absence there of King's lithofacies (OE, unpubl. data), Wadi Rimeileh (mouth at $31^{\circ} 10^{\prime} 22^{\prime \prime}$ N, 35³2'12” E) is apparently not synonymous with Wadi At Tayan, but represents a valley unnamed on the 1: 50,000 geological map sheet and situated between Wadi Issal and Wadi At Tayan at exactly the geographic position given by King (1923) (Text-fig. 1). In addition, according to new observations (OE, unpubl. data), the Burj Formation in this area is exclusively represented by the Hanneh Member siltstones and sandstones, which is in accordance with the 1: 50,000 geological map sheet. This supports the geographic locations discussed above.

\section{GEOLOGICAL SETTING}

The Dead Sea Rift Valley, which separates the Arabian Plate from the African Plate, is situated at the northern part of the Cenozoic Great Rift Valley but represents an extensional structure related to a triple junction active in late Proterozoic to early Cambrian times (Bender 1968a; Husseini 1989; Sharland et al. 2001). Crystalline basement rocks of the Arabian-Nubian Shield (Aqaba Complex) are exposed at its southern edge in the southern Wadi Araba, and are unconformably overlain to the north by Neoproterozoic (Araba Complex) and/or early Palaeozoic sedimentary rocks (Ram Group) (e.g. Bender 1968b; Segev 1984; Amireh et al. 1994; Elicki 2007; Schneider et al. 2007).

Cambrian rocks in the Middle East region are known from scattered, isolated outcrops in the Dead Sea area, the Wadi Araba and southward to Wadi Rum in Jordan, as well as from the Timna region in the southern Negev Desert, Israel, and from minor outcrops on the Sinai Peninsula, Egypt.

Onlapping the Arabian-Nubian Shield in the south, the thickness of the Cambrian rock succession increases northward to nearly $700 \mathrm{~m}$ in the Dead Sea area, and to probably more than $1000 \mathrm{~m}$ in the subsurface of northern Jordan and southern Syria (Bender 1968b; Powell 1989; Shinaq and Bandel 1992; Best et al. 1993).

In the study area at the northeastern and the southeastern edge of the Dead Sea and in the northeastern Wadi Araba (Text-fig. 1), the Cambrian succession (Text-fig. 2) starts with conglomeratic, fluvial and alluvial plain siliciclastics of the Umm Gaddah Formation (up to $60 \mathrm{~m}$ thick, late Ediacaran to Early Cambrian; Amireh et al. 2008) and Salib Formation (probably more than 200 m thick, Early Cambrian; Selley 1972; Powell 1989; Amireh et al. 1994; Makhlouf 2003). Deposition of the Salib Formation was occasionally influenced by marine ingressions in its upper part and the 
formation is overlain by the ?late Early to Middle Cambrian marine Burj Formation (up to $120 \mathrm{~m}$ in the Dead Sea area), followed by predominantly continental siliciclastics of the Umm Ishrin Formation. In southern Jordan, the siliciclastic rocks of the Abu Kusheiba Formation represent lateral facies types equivalent to strata of the Burj Formation. The Cambro(?)-Ordovician mainly fluvial Disi Formation overlies the Umm Ishrin Formation and wedges out from south to north in the Wadi Dana area.

The main marine incursion of this succession is represented by the Burj Formation, which is a mixed siliciclastic-carbonate unit with a complex architecture (Rushton and Powell 1998; Elicki 2007; Shinaq and Elicki 2007). It is subdivided into three members termed the Tayan (Tayan Siltstone), Numayri (Numayri Dolomite Shale) and Hanneh (Hanneh Siltstone) members. The Tayan Member consists of transgressive siltstones and sandstones with sporadic dolomite intercalations and attains a thickness of up to $21 \mathrm{~m}$ (Elicki 2007). The known fossil content is restricted to simple trace fossils and sporadic stromatolitic horizons (Powell 1989; Rushton and Powell 1998; Elicki 2007). The overlying Numayri Member (up to about $120 \mathrm{~m}$ in the Dead Sea area; Andrews 1991) consists of shallow marine limestones, dolostones and few marly siliciclastics. The carbonates are commonly rich in shelly fossils (trilobites, hyoliths, brachiopods, echinoderms, sponges and others; Elicki 2011). Distinct horizons yield stromatolites (Shinaq and Bandel 1992; Rushton and Powell 1998; Elicki et al. 2002; Shinaq and Elicki 2007). The sandstone-dominated siliciclastic Hanneh Member has yielded a few trilobite remains at its base and rich trace fossil assemblages (Makhlouf and Abed 1991; Amireh et al. 1994; Rushton and Powell 1998; Mángano et al. 2007; Shinaq and Elicki 2007; Hofmann et al. 2012; Mángano et al., in press). The Burj Formation is interpreted as a marginal to shallow marine succession deposited during a relatively short marine ingression on the southerly exposed basement rocks or on their continental detritus (e.g., Amireh et al. 1994; Rushton and Powell 1998; Elicki 2007).

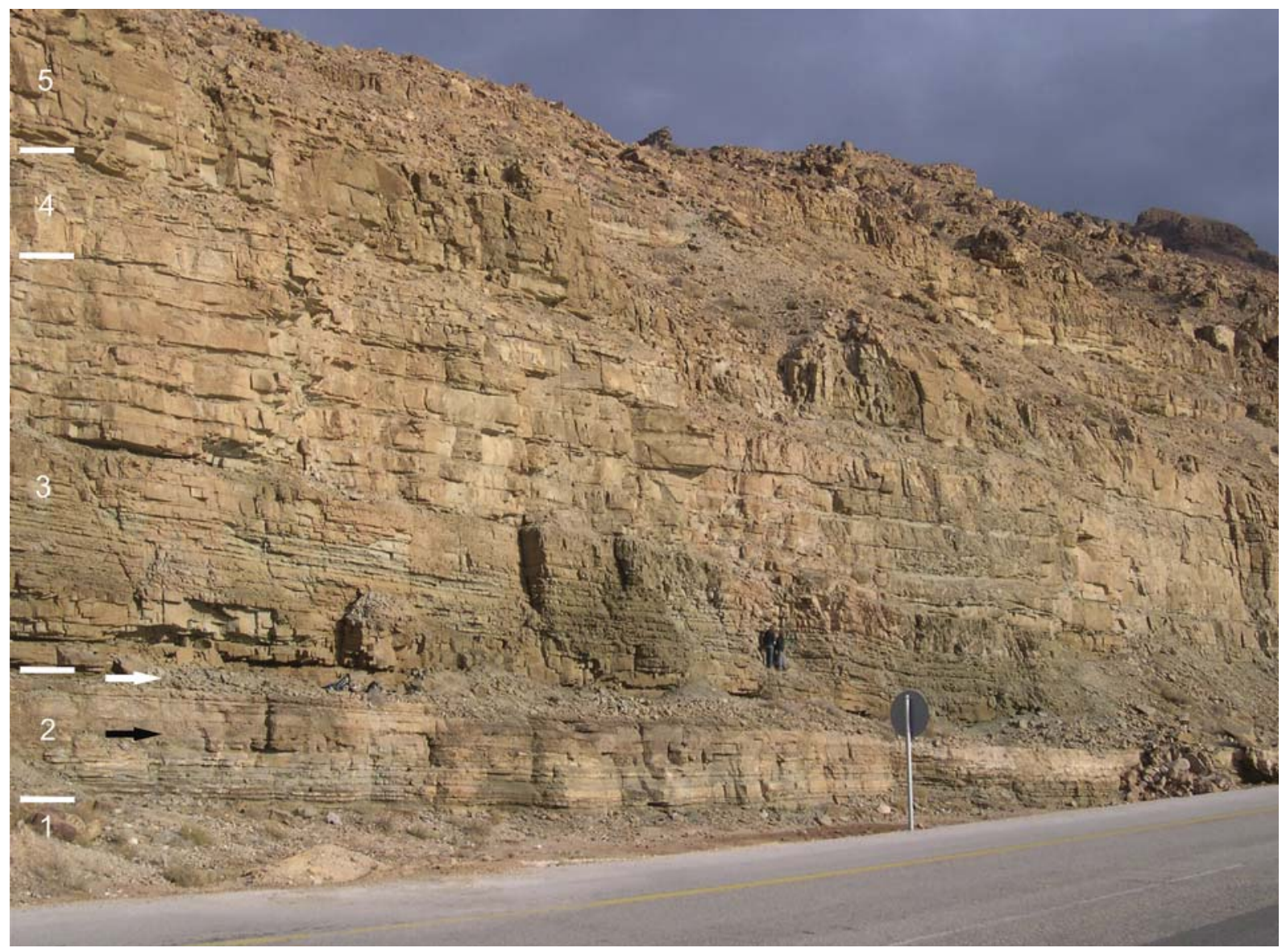

Text-fig. 3. Classic Wadi Zerqa Ma'in section one kilometre south of the mouth of Wadi Zarqa Ma'in (NE of Dead Sea). The outcrop exposes the upper part of the Numayri Member and a considerable part of the Hanneh Member. The facies differs from the sections of the southern Dead Sea region (see Shinaq and Elicki 2007, for details). Lithologic units are indicated in Fig. 2 and briefly described in the text. The black arrow indicates the horizon with Enixus cf. antiquus, the white arrow that 


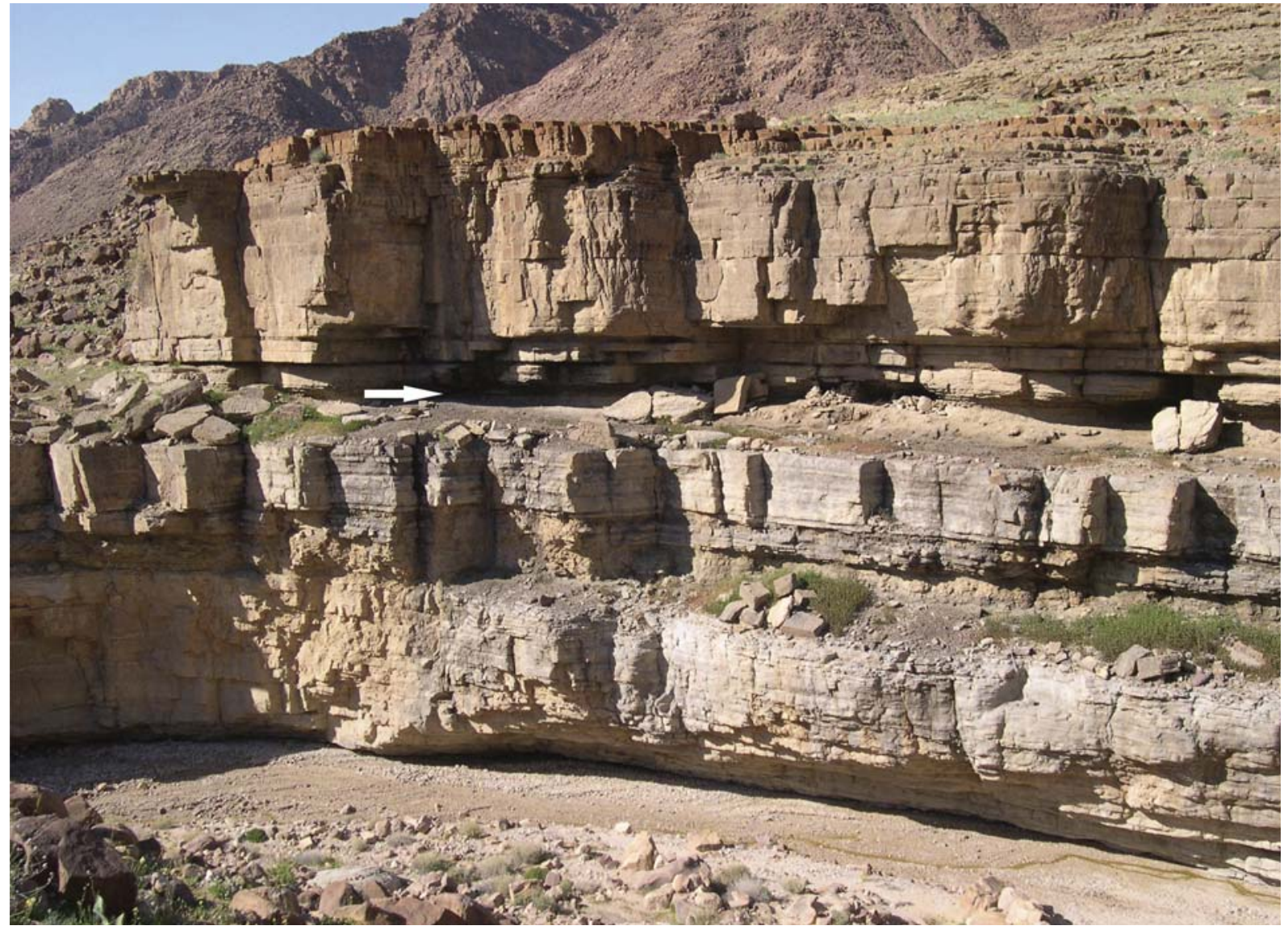

Text-fig. 4.Wadi Uhamir section, SE of Dead Sea, Numayri Member (base not exposed) with succession of limestones with different microfacies and alternating limestone-marlstone units. Trilobite-bearing limestone-marlstone unit marked by white arrow. The uppermost part of the member is made up of partly stromatolitic dolostones (brown layers at top) and is overlain by siliciclastics of the Hanneh Member. Photo: O. Elicki

\section{STRATIGRAPHY AND FOSSIL OCCURRENCES}

The northernmost known fossiliferous Cambrian outcrop near the mouth of Wadi Zerqa Ma'in (see Shinaq and Elicki 2007 and Text-figs 1,2) was discovered by K.A. Campbell in the beginning of the twentieth century. Campbell's material and additional trilobites from the southern Dead Sea area have been studied by King (1923), Richter and Richter (1941), and Picard (1942).

The Cambrian of the western margin of the Dead Sea Rift Valley in the southern Negev in Israel was examined by Parnes (1971). Roughly equivalent strata were first studied in the Timna area and at Har "Amram (Parnes 1971). These strata of the southern Negev yield trilobite assemblages with taxa which are, in part, in need of a revision (Geyer and Landing 2000).

In the Cambrian of the Dead Sea and Timna areas, trilobites and other shelly fossils are known exclusively from a fairly thin interval at the traditional Lower-Middle Cambrian boundary. Older early Cambrian and younger mid to possibly late Cambrian rocks are interpreted as mainly fluvial sequences (e.g., Bender 1968b;
Selley 1972; Powell 1989; Pflüger 1990; Makhlouf and Abed 1991; Makhlouf 2003; Schneider et al. 2007). Nevertheless, at least one marine ingression, represented by a thin interval with trace fossils generated by arthropods (Diplichnites, Cruziana, Rusophycus and others), have been identified from regions such as the northern Wadi Rum near the Jordanian-Saudi Arabian border (Geyer and Landing 2000; OE, unpublished data).

The fossiliferous rocks of the traditional LowerMiddle Cambrian boundary interval belong to a depositional sequence composed of the Umm Gaddah, Salib, Burj, Umm Ishrin and Disi formations (Selley 1972; Powell 1989; Amireh et al. 2001, 2008), which can be traced westward into the Timna region, where the three middle units are termed the Amudei Shelomo, Timna, and Shehoret formations (Karcz and Key 1965; Weissbrod 1981; Segev 1984).

Simplified, the marine incursion (Burj Formation) reflects a transgressive-regressive cycle (Rushton and Powell 1998; Elicki 2007), with the shelly fossils marking the marine highstand. This development reflects a 
Hawke Bay-type transgression at the Lower-Middle Cambrian turnover.

The trilobite faunas from the Burj and Timna formations have long been known, but the oligospecific assemblages have been imperfectly studied (Richter and Richter 1941; Parnes 1971; Rushton and Powell 1998). Rushton and Powell (1998) presented a meticulous analysis of the trilobites of the Burj Formation. They distinguished between a level with Kingaspis campbelli and Enixus cf. antiquus (as Palaeolenus antiquus) in the upper part of the Numayri Member and a slightly lower level with Tayanaspis bulbosus (as Realaspis sp. nov.), Redlichops blanckenhorni and Myopsolenites palmeri (as Onaraspis palmeri). However, the Kingaspis campbelli faunule is known only from limestones of the classic Wadi Zerqa Ma'in locality. The taphonomic aspects of these limestones (composed of high energy shell accumulations) suggest that the beds represent an ecostratigraphic horizon. The Redlichops faunule is known only from other southwardly located sites and occurs in quite variable carbonate-dominated rocks with notable shaly intercalations, which are interpreted to have been deposited in environments with generally low to moderate wave energy. Fairly intermittent trilobite occurrences contrast with few accumulations of various brachiopods (Cooper 1976). The puzzling occurrence of Hesa problematica (see below) also belongs to this level. In conclusion, the depositional and taphonomic aspects do not allow the Kingaspis campbelli faunule and the Redlichops faunule to be regarded as as distinct biostratigraphic levels.

It should be noted that the Burj-equivalent Timna Formation of the Negev region is also divided into three members, termed the Hakhlil, Sosgun, and Mikhrot members (Segev 1984). The known trilobites from the formation include Myopsolenites palmeri and Timnaella spp., and all come from the Hakhlil Member, which con- tains extremely shallow marine to peritidal and subaerial to locally lacustrine deposits, with the most unrestricted marine deposits close to the top. The report of Myopsolenites palmeri from the Mikhrot Member (Parnes 1971) appears be erroneous and based on local stratigraphic complications (E. Landing and G. Geyer, unpubl. data). In addition to the trilobites, these beds are locally rich in trace fossils such as Cruziana, "Monocraterion" and Planolites (Geyer and Landing 2000 and unpubl. data).

\section{CORRELATION}

The potential of the trilobite occurrences in the Dead Sea and Timna areas to enhance regional and even intercontinental correlation have been widely ignored. The reason was simply that the trilobites were either recognized as endemics or mismatched with genera or species erroneously identified from elsewhere. Even with the new taxa described by Rushton and Powell (1998) and in this study, correlation is not straightforward.

The classic Kingaspis campbelli was the first trilobite which became well known from the area and was utilized for correlation. This species was the first strongly effaced trilobite from a wider stratigraphic interval, and similarly effaced trilobites from the traditional Lower and Middle Cambrian boundary interval were frequently interpreted as close relatives, or even regarded as synonyms, and used as a basis for correlation. These largely arbitrary correlations are not discussed herein. The study of the ellipsocephaloid trilobites of the Moroccan Atlas ranges (Geyer 1990b) unfolded a complex taxonomic scheme of the group and showed that the trilobites previously grouped under Kingaspis Kobayashi, 1935 in fact represented at least three different genera. Even the restricted concept of Kingaspis

\begin{tabular}{|c|c|c|c|c|}
\hline Locality & Wadi Zerqa Ma'in & Wadi Issal & Wadi Uhaymir & Wadi Umm Jafna \\
\hline $\begin{array}{l}\text { Kingaspis } \\
\text { campbelli } \\
\text { faunule }\end{array}$ & $\begin{array}{l}\text { Kingaspis } \\
\text { campbelli } \\
\text { Enixus cf. } \\
\text { antiquus }\end{array}$ & & & \\
\hline $\begin{array}{l}\text { Redlichops } \\
\text { faunule }\end{array}$ & & $\begin{array}{l}\text { Issalia scutalis } \\
\text { Myopsolenites } \\
\text { palmeri }\end{array}$ & $\begin{array}{l}\text { Redlichops } \\
\quad \text { blanckenhorni } \\
\text { Timnaella? cf. orientalis } \\
\text { Tayanaspis bulbosus } \\
\text { Uhaymiria glabra } \\
\text { Myopsolenites hyperion } \\
\text { Myopsolenites palmeri } \\
\text { Genus and sp. undet. } 1 \\
\text { Genus and sp. undet. } 2\end{array}$ & $\begin{array}{l}\text { Cambrunicornia? } \\
\text { jafnaensis n. sp. } \\
\text { Genus and sp. } \\
\text { undet. } 3\end{array}$ \\
\hline
\end{tabular}

Text-fig. 5. List of Cambrian trilobites described from Jordan 


\begin{tabular}{|c|c|c|c|c|c|}
\hline & & IBERIA & ANTI-ATLAS & JORDAN & $\begin{array}{l}\text { HOLY CROSS } \\
\text { MOUNTAINS }\end{array}$ \\
\hline \multirow{5}{*}{ 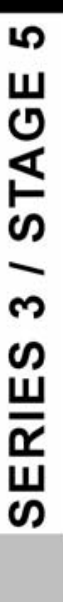 } & \multirow{5}{*}{$\begin{array}{l}Z \\
\mathbb{Z} \\
N \\
0 \\
0 \\
\mathbb{0}\end{array}$} & \begin{tabular}{|c|} 
Eccaparadoxides \\
asturianus \\
Zone \\
\end{tabular} & $\begin{array}{l}\text { Kymataspis } \\
\text { arenosa } \\
\text { Zone }\end{array}$ & \multirow{4}{*}{$\begin{array}{c}\text { Kc Kingaspis } \\
\text { campbelli- } \\
\text { Enixus } \\
\text { cf. antiquus } \\
\text { faunula }\end{array}$} & $\begin{array}{c}\text { Eccaparadoxides } \\
\text { pinus } \\
\text { Zone }\end{array}$ \\
\hline & & $\begin{array}{l}\text { Eccaparadoxides } \\
\text { sdzuyi } \\
\text { Zone }\end{array}$ & $\begin{array}{l}\text { Ornamentaspis } \\
\text { frequens } \\
\text { Zone } K c\end{array}$ & & \multirow{3}{*}{$\begin{array}{c}\text { Acadoparadoxides } \\
\text { insularis } \\
\text { Zone }\end{array}$} \\
\hline & & $\begin{array}{c}\text { Acadoparadoxides } \\
\text { mureroensis } \\
\text { Zone Am }\end{array}$ & \multirow[t]{2}{*}{$A m$} & & \\
\hline & & \multirow{2}{*}{$\begin{array}{c}\text { Protolenus (H.) } \\
\text { jilocanus } \\
\text { Zone Ma }\end{array}$} & & & \\
\hline & & & Zone & atoryctocar: & granulata \\
\hline \multirow{2}{*}{ 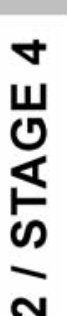 } & & $\begin{array}{c}\text { Protolenus }(H .) \\
\text { dimarginatus } \\
\text { Zone Hd }\end{array}$ & $\mathrm{Hd}$ & \multirow[t]{3}{*}{$\begin{array}{c}\text { Mh Mpdlichops- } \\
\text { Tayanaspis } \\
\text { faunula }\end{array}$} & \multirow{3}{*}{$\begin{array}{l}\text { Protolenus- } \\
\text { Issafeniella } \\
\text { Assemblage } \\
\text { Zone }\end{array}$} \\
\hline & & & $\begin{array}{l}\text { Hupeolenus } \\
\text { Zone }\end{array}$ & & \\
\hline$\frac{\omega}{\frac{w}{\alpha}}$ & 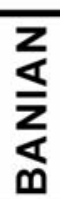 & Realaspis & $\begin{array}{c}\text { Sectigena } \\
\text { Zone }\end{array}$ & & \\
\hline
\end{tabular}

Text-fig. 6. Tentative correlation chart of the traditional Lower-Middle Cambrian boundary interval in West Gondwana (Iberia, Moroccan Atlas ranges, Jordan), and Holy Cross Mountains, Poland and the approximate stratigraphic occurrences of the important species Myopsolenites altus (Ma), Myopsolenites hyperion (Mh), Myopsolenites palmeri (Mp), Myopsolenites kielcensis (Mk), Protolenus (Hupeolenus) dimarginatus (Hd), Kingaspis campbelli (Kc), and Acadoparadoxides mureroensis $(\mathrm{Am})$. The tentative FAD level of Ovatoryctocara granulata is shown by the wide grey line

included species which occur in at least three different zones in the Moroccan Cambrian. Kingaspis campbelli was identified from the easternmost Anti-Atlas close to the Moroccan-Algerian border, but unfortunately in rocks which cannot be placed unequivocally into one distinct zone. According to the existing zonation for the Atlas ranges (Geyer 1990a), the species occurs either in the upper part of the Morocconus Zone (formerly the Cephalopyge Zone ${ }^{1}$ ) or in the overlying Ornamentaspis frequens Zone (Geyer 1990b), which are coeval with part of the lower (but not lowest) range of Paradoxides s. 1. and thus the base of the traditional 'Acadobaltic' Middle Cambrian (compare Geyer and Landing 2004; Geyer 2005; Geyer and Peel 2011).
Specimens of Kingaspis from the Iberian Chains, northern Spain, as well as specimens from the Láncara Formation of the Cantabrian Mountains have been identified as K. campbelli (Liñán et al. 2003; Dies et al. 2004). As outlined by Geyer and Landing (2004), this identification is certainly erroneous (see discussion under K. campbelli), but was maintained by Gozalo et al. (2007) and further used for direct correlation. The specimen from the Valdoré section figured by Gozalo et al. (2007, fig. 4A) shows the shell exterior with features characteristic of Kingaspidoides Geyer, 1990 rather than Kingaspis. The Iberian material from Aragón occurs in the local Protolenus dimarginatus Zone, where specimens notoriously suffer from notable tectonic distortion.

\footnotetext{
${ }^{1}$ The name Cephalopyge Geyer, 1988 for the trilobite genus and the eponymous zone is a junior homonym of Cephalopyge Hanel, 1905, a Recent phylliroid nudibranch. The senior author of this paper had been aware of this and had started preparation of a short manuscript in which the name Cephalopyge Geyer, 1988 would have been replaced and some of the morphological details of the trilobite Cephalopyge further scrutinized. In a sort of nomenclatural piracy, a colleague recently suggested the new name Morocconus without having had any contact with any of the authors affected by the article in question (Özdikmen H. 2009, Nomenclatural changes for Twenty trilobites [sic] genera. Mun. Ent. Zool. Vol. 4, No. 1, 155-171)
} 
The eponymous Protolenus (Hupeolenus) dimarginatus Geyer, 1990 is a species first described from the $\mathrm{Mo}$ rocconus Zone of southern Morocco, where it most probably spans its lower and middle part and appears to range into the top of the underlying Hupeolenus Zone of Morocco, which is primarily characterized by other species of Protolenus (Hupeolenus) such as P. (H.) hupei Geyer, 1990 and $P$. (H.) termierelloides Geyer, 1990 (e.g., Geyer 1990a; Geyer and Landing 2006). Gozalo et al. (2007, p. 367) erroneously state that this species, as well as Protolenus (P.) interscriptus, have been "defined [...] in the Hupeolenus zone." Both were in fact described from the Morocconus Zone of Morocco, and $P$. (P.) interscriptus is restricted to this zone (Geyer 1990b). Summarized, there is little likelihood that Protolenus (Hupeolenus) dimarginatus and Kingaspis campbelli could occur together in the Moroccan sections. Furthermore, Protolenus (Hupeolenus) termierelloides is also identified from the Protolenus (Hupeolenus) dimarginatus Zone of the Iberian Chains (Dies et al. 2004, as "cf. termierelloides"; Gozalo et al. 2007). This species ranges in Morocco from the acme in the Hupeolenus Zone into the base of the Morocconus Zone. As detailed earlier, its identification is based on material inadequate for a precise determination (see Gozalo et al. 2007, fig. $5 \mathrm{G})$. The situation is even more skewed as the Iberian Protolenus dimarginatus Zone is overlain by the Protolenus jilocanus Zone (formerly the Hamatolenus ibericus Zone) and the Acadoparadoxides mureroensis Zone, which marks the base of the Middle Cambrian in Iberia. Paradoxides (A.) mureroensis Sdzuy, 1957 has not yet been described and figured from the Moroccan Atlas ranges but occurs there in some sections in the Morocconus Zone. Its first occurrence is always well above the base of the zone (G. Geyer and A. Vincent, unpubl. results). In contrast, Paradoxides (A.) nobilis Geyer, 1997 has its first occurrence at or even below the base of the Morocconus Zone, and that species has been erroneously synonymized with $P$. (A.) mureroensis, which led to the report of the latter species as existing in Morocco (e.g., Sdzuy 1995; Sdzuy et al. 1999; Liñán et al. 2002). Hence, some of the identifications of the Spanish material appear to obscure the quite obvious correlation between Iberia and southern Morocco, which are reinforced by depositional patterns with distinct transgressive events (Álvaro et al. 2003; Landing et al. 2006).

Another trilobite linking between Iberia, Morocco and Jordan is Myopsolenites. The genus was unfortunately established in an unusually brief manner (Öpik 1975), which has created unnecessary confusion (see Geyer and Landing 2004, and discussion below). Despite notable morphological differences, Gozalo and Liñán (1997), Rushton and Powell (1998), Gozalo et al. (2007) and Dies Álvarez et al. (2007) synonymized Myopsolenites with the endemic Australian genus Onaraspis. As discussed below, both genera are interpreted herein to represent members of the Bathynotidae; a small family which has a strong and short acme at the traditional Early-Middle Cambrian boundary interval. In addition to Myopsolenites palmeri, M. hyperion sp. nov. is another species which occurs in Jordan, and additional, morphologically similar species are known from southern Morocco, the Holy Cross Mountains in Poland, the Iberian Chains and the Cantabrian Mountains in Spain. All of the Moroccan material comes from the Morocconus Zone (Geyer and Landing 2004). The material from the Iberian Chains was found in the Protolenus jilocanus Zone (Gozalo et al. 2007). However, based on new material published by Dies et al. (2007), it can be shown that the Spanish species Myopsolenites altus (Liñán and Gozalo, 1986) is a senior synonym of the Moroccan Myopsolenites boutiouiti Geyer and Landing, 2004 (see discussion below under Myopsolenites in the systematic section). The above-mentioned species plus additional faunas enable an apparently precise correlation between the Moroccan Atlas ranges and the Iberian Chains, with a fairly reliable correlation into other regions of West Gondwana and into the Holy Cross Mountains (Text-fig. 6). However, these correlations deviate notably from those presented by Dies et al. (2007, fig. 5). The reason for this is either that the precise stratigraphic ranges of these and additional accompanying trilobite species are not known, or that the correlations from the Iberian successions into other areas are incorrect.

A species of Enixus (formerly Schistocephalus) occurs in association with Kingaspis campbelli in the Dead Sea area. The species is dealt with herein as Enixus cf. antiquus and has been identified as Palaeolenus antiquus by Rushton and Powell (1998). Enixus antiquus is the index fossil of the lower Amgan Schistocephalus antiquus Zone. Our tentative identification refers to minor differences which are difficult to quantify taxonomically. However, regardless of these differences, it can be assumed that the form permits a direct stratigraphic correlation into the lower part of the Siberian Amga Stage. Complications arise, however, if the former genus Schistocephalus is merged with Palaeolenus Mansuy, 1912 and Megapalaeolenus Chang, 1966, as suggested by Lin and Peng (2004). The morphological concepts and taxonomic consequences are discussed below under Enixus. Stratigraphically, there exists a morphological lineage from species of Palaeolenus to species of Megapalaeolenus, which indicates that a considerable amount of time is involved so that a collective genus Palaeolenus has little significance for correlation. More important is that another probable 
species of Enixus has been found in the Morocconus Zone of the High Atlas mountains, associated with Clavigellus Geyer, 1994, a genus which was found in the $P$. (A.) mureroensis level in the lower Láncara Formation of the Cantabrian Mountains (Gozalo et al. 2007), in the lower part of the Campo Pisano Formation of Sardinia, together with the oldest Acadoparadoxides specimens (Elicki and Pillola 2004), and in the Çal Tepe Formation of the Amanos Mountains, Turkey, where it occurs with $P$. (A.) cf. mureroensis (Dean and Özgül 1994; Dean 2005). Palaeolenus medius (Bednarczyk, 1970) has been found in the Holy Cross Mountains, in strata which also yielded Paradoxides (A.) cf. mureroensis (Żylińska and Masiak 2007).

Yuan et al. (2009) used the taxonomic lumping of Schistocephalus with Palaeolenus and a supposed similarity of Enixus antiquus with Megapalaeolenus deprati (Mansuy, 1912) to correlate the base of the Amgan Stage roughly with the upper part of the Megapalaeolenus Zone, or the Arthricocephalus chauveaui Zone in South China. The presence of Ovatoryctocara granulata Chernysheva, 1962, in the Henson Gletscher Formation of North Greenland, in strata above the level with Arthricocephalus chauveaui Bergeron, 1899, enables to falsify the correlation suggested by Yuan et al. (see comprehensive discussion in Geyer and Peel 2011). Ovatoryctocara granulata, a candidate GSSP marker for the base of the proposed Cambrian Series 3 (to replace the traditional Middle Cambrian), is a fairly common trilobite in the lower Amgan of the Yudoma-Olenek facies region, where it defines the lowermost Amgan biozone and thus the base of the Middle Cambrian series in Siberia (e.g., Korovnikov 2001; Shabanov et al. 2008; Naimark et al. 2011). The species is also present in Guizhou, South China, where it occurs in the Ovatoryctocara granulataBathynotus holopygus Zone of the Duyunian (Yuan et al. 1997, 2001, 2002). In addition, specimens of $O$. granulata have been found in the uppermost Brigus Formation of southeastern Newfoundland, Canada, a part of Western Avalonia (Fletcher 2003). The single occurrence at Easter Cove, southeastern Newfoundland, is underlain by shales in which Hamatolenus (Hamatolenus) cf. meridionalis Geyer, 1990 has been found [Fletcher 2006, pl. 27, fig. 35, described as "Hamatolenus $(H$.) sp. aff. $H$. (H.) marocanus (Neltner, 1938)"]. Hamatolenus (H.) meridionalis is known from the lower Morocconus Zone of the shaly facies of the Jbel Wawrmast Formation in the western Anti-Atlas (Geyer 1990b). A further constituent of the uppermost Brigus Formation of southeastern Newfoundland is Condylopyge eli Geyer, 1997, a trilobite first described from the Morocconus Zone of the Moroccan Anti-Atlas, and Morocconus notabilis, the index fossil of that Moroccan zone was also found in southeastern
Newfoundland in the Brigus Formation (Fletcher 2003, 2006). Therefore, the Morocconus Zone of the Moroccan Atlas ranges and equivalent strata in western Avalonia correlate at least in part with the Ovatoryctocara granulata Zone in Siberia and northern Greenland and the Ovatoryctocara granulata-Bathynotus holopygus Zone of the Duyunian in South China. A detailed discussion is provided by Geyer and Peel (2011). The Kingaspis campbelli and Redlichops faunules of Jordan are also best correlated with the Morocconus Zone, possibly with its upper part. They would thus be equivalents of the O. granulata level with the acme of Bathynotus species and the Paradoxides (A.) mureroensis Zone of Iberia. If Ovatoryctocara granulata is selected to mark a GSSP for the base of the Cambrian Series 3 and Stage 5 , the trilobite occurrences in Jordan would thus indicate the basal strata of those units.

\section{SYSTEMATIC PALAEONTOLOGY}

\author{
Superfamily Redlichioidea Poulsen, 1927 \\ Family uncertain
}

Genus Redlichops Richter and Richter, 1941

TYPE SPECIES: Redlichia (Redlichops) blanckenhorni Richter and Richter, 1941; by original designation.

DISCUSSION: As detailed by Rushton and Powell (1998), the traditional systematic position of the endemic monotypic genus Redlichops within the Subfamily Pararedlichiinae (Zhang 1966; Zhang et al. 1980) cannot be maintained. Clearly distinguishing characters are the moderately wide (rather than distinctly slender) interocular area, the shape of the palpebral lobes, and primarily, the character of the glabella. In particular, the pattern of the glabellar furrows, with S3 distant from the axial furrows, the shallow but widened median portion of the occipital furrow, as well as the parafrontal band and the anterior progression of the eye ridges, are all characters of advanced redlichioids. Taking into account the huge amount of material of Redlichops blanckenhorni collected without a pygidium attributable to the species, we must assume that Redlichops is micropygid. These characters do not allow Redlichops to be placed into an established family with any degree of confidence.

Redlichops blanckenhorni Richter and Richter, 1941 (Text-figs 7 and 8) 
1910. Eiförmige Glabellen von Conocephaliden; Blanckenhorn, p. 411.

1910. Ptychoparia; Schmidt in Blanckenhorn, p. 412.

?1910. Paradoxides?; Schmidt in Blanckenhorn, p. 412 (pygidium only).
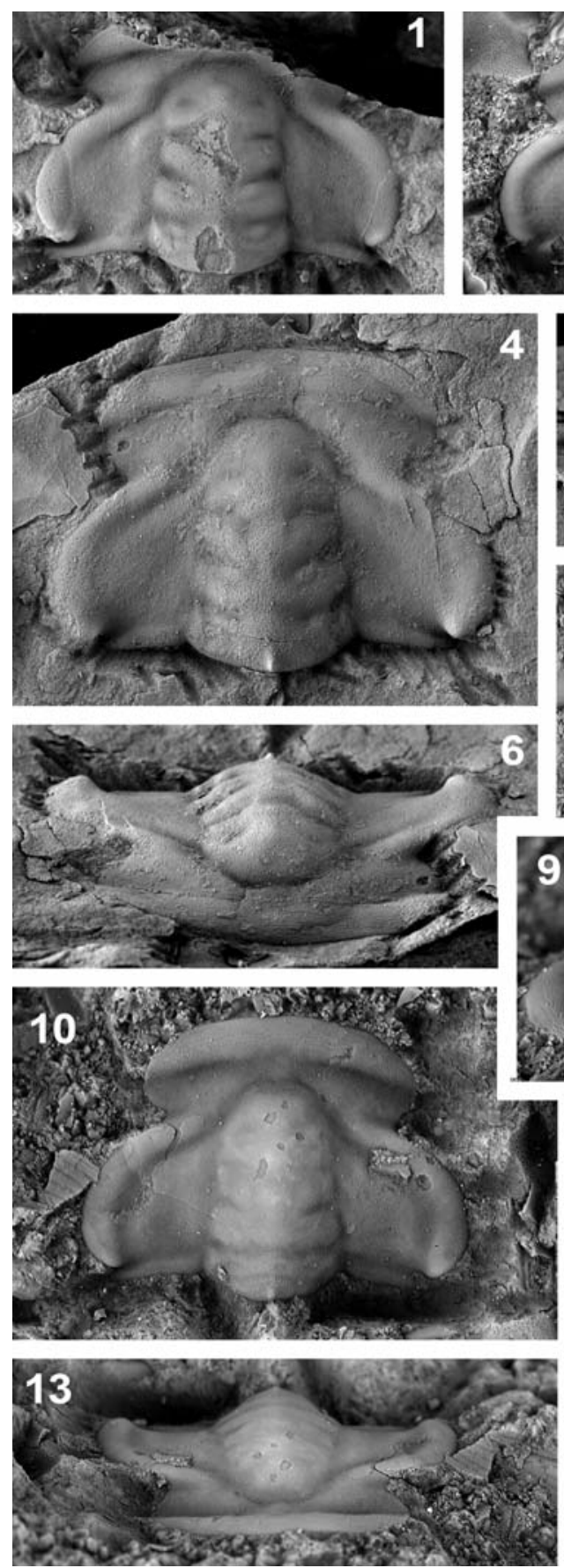

Text-fig. 7. Redlichops blankenhorni Richter and Richter, 1941; all specimens from the Wadi Uhaymir section. 1-15 - cranidia. 1-FG-602-003, incomplete cranidium, dorsal view, $\times 3$; 2, 3-FG-602-009a, incomplete cranidium, dorsal views; 2 , entire specimen, $\times 3$; 3, detail, $\times 5$; 4-6 - FG-602-058a, semigerontic cranidium, dorsal, left lateral and anterior views, $\times 2 ; 7-$ FG-602-024c, incomplete cranidium, dorsal view, x 3; 8-FG-602-027, incomplete cranidium, dorsal view, $\times$ 3; 9, 10, 13 - FG-602-016a, cranidium of young individual, left lateral, dorsal, and anterior views, $\times 5$ each; 11, 12, 14, 15 - FG-602-039a, incomplete cranidium; 11, anterior view, $\times 3 ; 12$, oblique right lateral view, $\times 3 ; 14$, dorsal view, $\times 3 ; 15$, detail, dorsal view, showing granulation of glabella, left fixigena and eye ridge.

Note muscular pits at occipital furrow and close to $\mathrm{S} 1$ and swelling on frontal lobe, $\times 8$

1912. Ptychoparia; Blanckenhorn, p. 129.

1915. Ptychoparia sp.; Dienemann, p. 25.

v 1941. Redlichia (Redlichops) blanckenhorni n. sp.; Richter and Richter, p. 15-18, pl. 2, figs 1, 2, 5?, 6a (only).
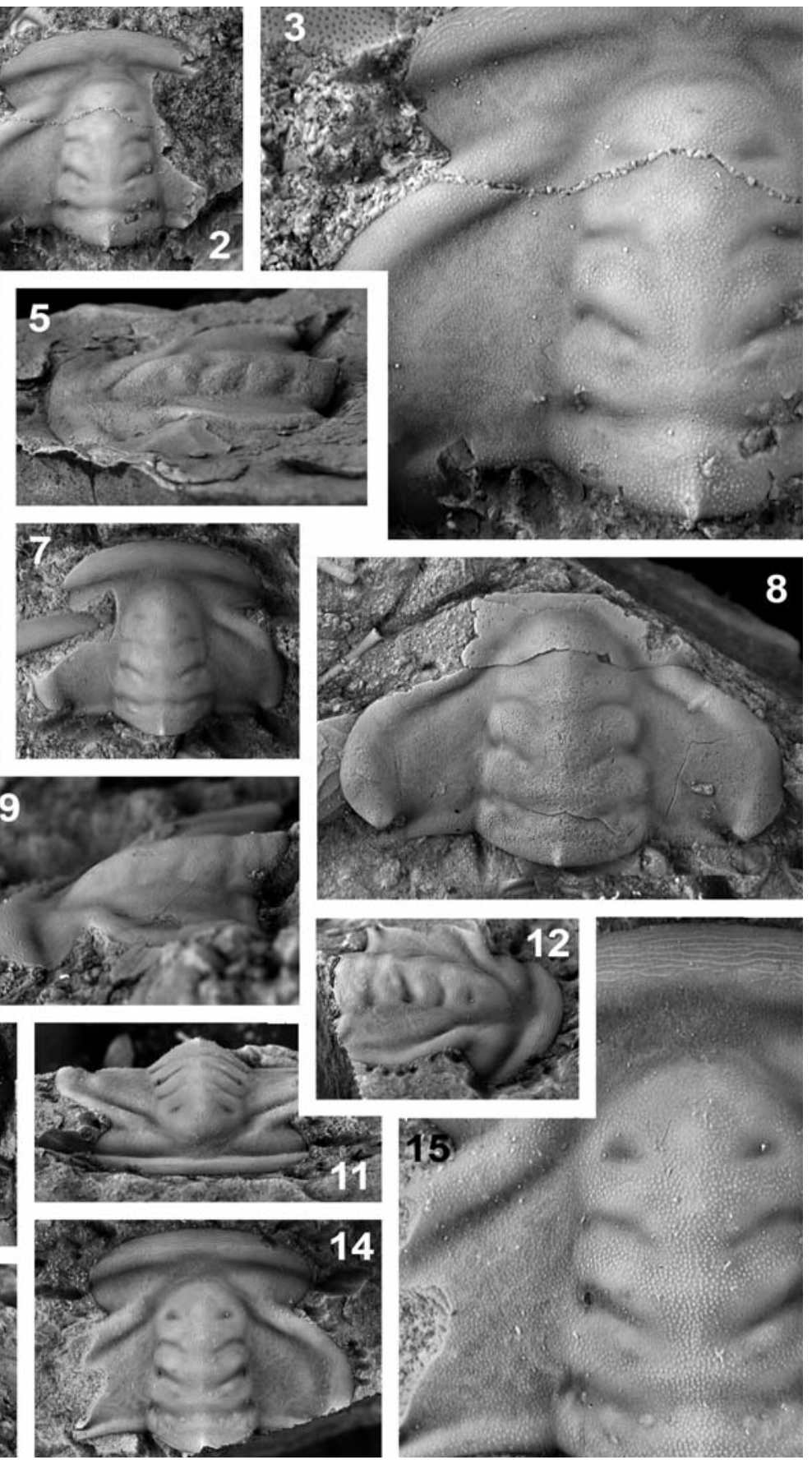
CAMBRIAN TRILOBITES OF JORDAN

non 1941. Redlichia (Redlichops) blanckenhorni n. sp.; Richter and Richter, pl. 2, figs 3, 6 b.

v 1959. Redlichops (R.) blankenhorni; Poulsen in Harrington et al., p. O201, fig. 141,8.

1976. Redlichops blankenhorni; Cooper, p. 273.

v 1997. Redlichops (R.) blankenhorni; Chang et al., p. O440-441, fig. 280,1.

1998 Redlichops blanckenhorni Richter and Richter, 1941; Rushton and Powell, p. 138-139, figs 7-9, 11-13 (only).
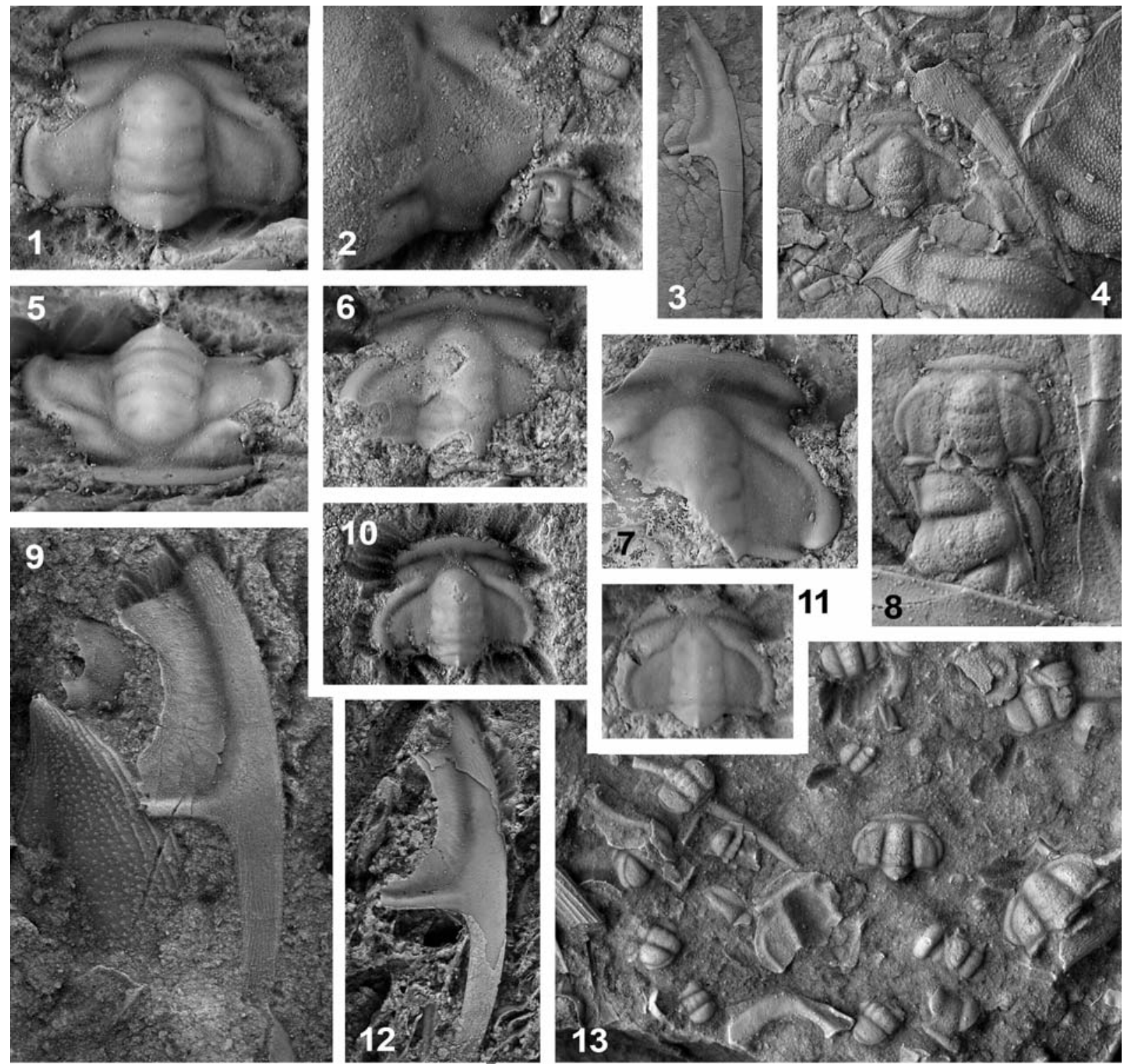

Text-fig. 8. 1-13 - Redlichops blankenhorni Richter and Richter, 1941; all specimens from the Wadi Uhaymir section. 1, 5- FG-602-032b, immature cranidium, dorsal and oblique anterior views, $\times 5 ; 2-$ FG-602-051c and $051 \mathrm{~d}$, juvenile cranidia next to cranidium of Myopsolenites palmeri, dorsal view, $\times 5$; $3-\mathrm{FG}-602-062 \mathrm{~h}$, incomplete librigena, $\times 3$; 4 - FG-602-035f, FG-602-035g, immature cranidia on slab with sclerites of Myopsolenites palmeri, dorsal view, $\times 3.5$; 6 - FG-602-019b, incomplete juvenile cranidium, dorsal view, note narrow anterior border, $\times 5 ; 7-\mathrm{FG}-602-007 \mathrm{c}$, fragmentary young cranidium, dorsal view; note pronounced boss, $\times 5 ; 8-$ FG-602-035, late larval cranidia, dorsal view, $\times 6$; $9-$ FG-602-055a, librigena, dorsal view, with terrace ridges on border and genal spine and caeca on extraocular area, $\times 2 ; 10-$ FG-602-019c, immature cranidium, dorsal view, $\times 5 ; 11-$ FG-602-017b, immature cranidium, dorsal view, $\times 5$; $12-\mathrm{FG}-602-055$, incomplete librigena, partly exfoliated, dorsal view, $\times 2 ; 13-\mathrm{FG}-602-046$, slab with numerous larval cranidia, $\times 3.5$ 
FG-602-035h, FG-602-035i, FG-602-035j, FG-602039a, FG-602-045a-e, FG-602-046a-j, FG-602-051c, FG-602-055, FG-602-056b, FG-602-058a, FG-602060b, FG-602-062e, FG-602-062f, FG-602-062g, FG-602-067a; all from Wadi Uhaymir.

The type material of the Richters (1941) was collected in 1908 and provisionally described by Blanckenhorn (1910), with Schmidt (in Blanckenhorn 1910), Blanckenhorn (1912), and Dienemann (1915) referring to the same material. The few specimens, housed in the Naturmuseum Senckenberg (Frankfurt a. M.), were noted by Blanckenhorn to have come from a locality "Chirbet el-Burdsch" (a German transliteration, nowadays best transcribed as "Khirbet al-Burj"; "Khirbet El Burj of Rushton and Powell 1998), to the southeast of Safi and close the southeastern banks of the Dead Sea. In fact, a village with this name is unknown from the area. Most probably, the name refers to the ruins of two houses on the slope overlooking Safi, built from a variety of rocks originating from the slope of the hill, but to a large extent constructed from Cambrian limestone blocks. Blanckenhorn appears to have collected a considerable amount of his Cambrian fossil samples from these ruins.

DESCRIPTION OF ADULT MORPHOLOGY: Cranidium with width/length ratio c. 1.3 to 1.4. Anterior margin gently curved. Palpebral lobes extending beyond tips of anterior sections of facial suture, with ocular furrows at about the distance of anterolateral corners from midline.

Glabella more than $75 \%$ of cranidial length and 36 to $39 \%$ of cranidial width across occipital ring; sides straight to S3, tapering progressively forward; frontal lobe curved, with tendency to slightly less curved oblique anterolateral sections; posterior section of frontal lobe faintly expanded due to fusion with projections of eye ridges, maximum width of frontal lobe c. $85 \%$ of maximum width of occipital ring; glabella with moderate transverse convexity. Three pairs of lateral glabellar furrows visible; S1 well developed, with deep pit adjacent to axial furrows, directed slightly rearward and fading to leave median gap of about quarter the width across glabella; well-preserved specimens show faint furrow parallel to and slightly posterior to S1, interpreted as vestige of bifurcation of S1; S2 well developed, with deepest impression a short distance from axial furrows, with only faint curvature, thus almost perpendicular to axis, fading to leave median gap of about one-third the width across glabella; S3 developed as shallow but clearly recognizable oval depression distant from axial furrows. Occipital furrow bifurcating, consisting of moderately well-developed anterior furrow with a slight backward swing, fading medially to show only faint connection, and a shallower posterior section with a more distinct curvature; the most posterior position of posterior branch of occipital furrow located about one-third of maximum breadth (sagittal) of occipital ring posterior to anterior branch; its proximal section ending in forward swing towards anterior branch, creating oval areas between branches. Occipital ring sagittal, c. 16 to $19 \%$ of cephalic length, with moderately curved posterior margin and a distinct and acute terminal node. Median sagittal area of glabella with at least two faint swellings: posterior faint knoll developed between occipital furrow and depression formed by S1; anterior swelling on L2; both indicating faint central granule which may have been the location of sensory organ.

Axial furrows varying considerably in depth and width, generally shallow, with maximum width next to anterior sectors of occipital ring and adjacent to L2, proceeding into shallow groove around frontal lobe. Fixigenae with low convexity, including longitudinal shallow depression along centre and slightly raised interior areas with highest elevations next to L2 and posterior part of L3; extend across centre of palpebral lobes to c. 50-55\% maximum width of occipital ring; exsagittal length slightly less than $40 \%$ (36-39\%) of cephalic length next to axial furrows. Highest elevation projecting into faint lobe, fused with anterior part of L3 and developed into barely recognizable parafrontal band. Wellpreserved specimens exhibiting anteriorly directed caecal lines on these preocular areas, indicating that at least three vascular threads extend from this region into the marginal area of the glabellar front. Caeca rarely preserved in distal portions of fixigenae, with vessels setting off from an arched trunk parallel to palpebral lobe (Text-fig. 7.15).

Palpebral lobes gently curved, subequal in width throughout, generally with moderate transverse convexity, distal portions with tendency to be more raised towards posterior, with most elevated parts close to posterior tips; breadth 18 to $26 \%$ of maximum occipital width, exsagittal length extending to almost half of cranidial length. Palpebral furrows quite narrow, weakly defined, well-developed posteriorly to eye ridges. Eye ridges projecting from palpebral lobes, slightly narrower but without change in elevation or transverse furrow; roughly three-times longer than wide; swinging abruptly forward next to glabella, projecting into a shallow lobe, surrounding frontal lobe of glabella; barely recognizable in width and elevation anterior to glabellar front.

Anterior branches of cephalic suture diverging moderately strongly from mid-portion of eye ridges, swinging medially in a gentle curvature in anterior third of preocular field to cut anterior border in distinctly oblique angle, located distinctly more ventrally than anterior end 
of visual surface. Posterior branches short, diverging strongly laterally and ventrally, with lateral tips of posterior border extending to nearly the level of palpebral lobes' maximum distance from midline.

Preglabellar field sagittally c. 6-7\% of cephalic length, with median plectrum becoming more and more inconspicuous during ontogeny, incompletely fused with parafrontal band, and creating an indentation of posterior margin of anterior border (Text-fig. 7.14). Preocular fields weakly convex, sloping ventrally, occasionally with faint and fairly irregular caeca.

Anterior border sagittally of c. 13 to $15 \%$ of cephalic length, defined posteriorly by relatively steep slope toward border furrows, medial surface of low convexity. Anterior border furrow a relatively narrow, poorly defined groove. Posterior border convex, weakly sigmoidal, of more-or-less equal breadth throughout. Posterior border furrow obsolescent.

The surface of cranidium with different types of ornamentation/prosopon. Anteriorly and laterally directed convex parts of glabella covered with fine- to mediumsized granules, as well as anterior portions of eye ridges. Ocular areas, preocular fields, anterior and posterior border generally covered with fine granules. Parts of glabella, adjacent to lateral and occipital furrows and proximal portions of palpebral lobes, smooth. Distal and medial part of anterior border with terrace lines, forming long scarps parallel to anterior cephalic margin in anterior position and becoming progressively shorter rearward.

On the exterior of the test, specimen FG-602-039a shows traces of muscle scars as imprints of the ventral surfaces. These scars are all pairs with symmetric arrangement in the glabella, situated on the anterior rim of the occipital ring, on both sides of S1 and S2, and as unpaired scars on the glabellar midline in L3 and the frontal lobe (Text-fig. 7.15).

Librigena with narrow extraocular area, about as wide as or slightly wider (tr.) than adjacent part of lateral border. Lateral border extends into a long genal spine (in adults at least as long as the anterior part of the librigena). Anterior and posterior sections of facial suture in accordance to that of the cranidium. Narrow ocular socle present along ocular suture. Lateral border and genal spine with longitudinal terrace lines, extraocular area with radial caeca. Doublure completely underlies borders, densely covered with longitudinal terrace lines.

Thoracic segments known only from small fragments; pleurae apparently almost twice the width of the axial rings. Pleural furrow distinctly delimited toward the anterior and less distinctly toward the posterior. Posterior rim of the pleurae more or less straight, curving slightly into an apparently moderately long spine.

ONTOGENETIC VARIABILITY: Small holaspid individuals of Redlichops blanckenhorni differ from large adult specimens primarily in the relative proportions and in the expression of furrows. The most conspicuous differences of the juveniles (compared to adults) are:

Cranidium transversely wider (compared to adults), length less than three-quarters width. Glabella wider (compared to adults), width across occipital ring more than $35 \%$ cranidial width, with sides subparallel or weakly tapering forward (in undeformed, non-flattened specimens), more than three-quarters cephalic length. Occipital ring sagittally broader (up to $20 \%$ cephalic length). Glabellar furrows shallower, less clearly impressed.

Fixigenae less structured morphologically, sunken between palpebral lobes and glabella, with only minor bacculae. Palpebral lobes long (exsag. length more than $40 \%$ cephalic length) and broad (width tr. more than $8 \%$ cranidial width across centre of palpebral lobes); eye ridges broad. Preglabellar field narrow, often developed as a sunken area created by confluent axial and anterior border furrows. Anterior border wide (up to more than $15 \%$ cephalic length), highly convex.

Late larval stages of Redlichops blanckenhorni have cranidia with a subparallel to slightly tapering glabella and with transverse, medially connected furrows, its frontal lobe reaching the anterior border furrow; occipital ring extending into a stout thorn; clearly convex fixigenae with an interior bacculate section and a more or less clearly visible oblique depression; palpebral lobes with posterior tips at the level of L1 or even more anteriorly and anterior tips laterally of the frontal lobe; short, subnodular eye lobes; anterior border narrow, thread-like.

DISCUSSION: For affinities of Redlichops blanckenhorni see discussion under Genus Redlichops.

Rushton and Powell (1998, fig. 10) described and figured a rostro-hypostomal plate, which they attributed to Redlichops blanckenhorni. This specimen would have placed the species under trilobites with conterminant hypostomal condition. However, the specimen must be attributed to Myopsolenites palmeri (Parnes, 1971) (see below for discussion).

Superfamily Ellipsocephaloidea Matthew, 1887 Family Ellipsocephalidae Matthew, 1887

Timnaella Parnes, 1971 
TYPE SPECIES: Timnaella eyali Parnes, 1971; by original designation.

DISCUSSION: The genus Timnaella was introduced by Parnes (1971) for small ellipsocephaloid-type trilobites from the Timna area, southern Negev. Parnes (1971) introduced two formal species (T. eyali and T. wingi) and referred additional material to as Timnaella sp. 1 and Timnaella? sp. 2. All of his material came from the Hakhlil Formation and is poorly preserved in a relatively coarse, rose-coloured to pinkish sandstone so that the details of the furrows and the surface ornament are unknown. Timnaella eyali is known from one and $T$. wing $i$ from two incomplete cranidia. The additional material is even less perfectly preserved and partly characterizes immature individuals so that some may indeed belong to $T$. eyali and T. wingi, respectively. Both species are in need of additional material for a more precise characterization.

The species first described as Protolenus orientalis by Picard (1942) from the Wadi Numayri, Jordan, and transferred to Resserops (Richterops) orientalis by Parnes (1971) shares most significant characters with Timnaella eyali and is thus transferred to Timnaella with certain caveats (see discussion below).

Timnaella? orientalis (Picard, 1942)

v 1942. Protolenus orientalis sp. nov.; Picard, p. 1-4, pl. 2, fig. 1.

non 1942. Protolenus orientalis sp. nov.; Picard, pl. 2, fig. 2.

v 1971. Resserops (Richterops) orientalis (Picard); Parnes, p. 186, 188-189, pl. 1, figs 1-4.

non 1971. Resserops (Richterops) orientalis (Picard); Parnes, pl. 1, fig. 5 (only).

? 1971. Strenuella (S.) sp. 2; Parnes, p. 193-194, pl. 1, figs $10,11$.

1976. Resserops (Richterops) orientalis; Cooper, p. 273.

1998. Realaspis? orientalis (Picard, 1942), Rushton and Powell, p. 136-137, 140.

DISCUSSION: The history of Timnaella? orientalis (Picard, 1942) is complicated and has not yet led to a satisfactory understanding of the species. Picard (1942) figured only a single cranidium as a simple line drawing (Picard 1942, pl. 2, fig. 1) with obvious minor inaccuracies that made an unequivocal determination difficult. The incomplete pleura figured by Picard (1942, pl. 2, fig. 2) as a second specimen of "Protolenus orientalis sp. nov." shows the ventral surface and probably is a pleura of Myopsolenites. Parnes (1971) restudied and refigured Picard's type material, which gives a fairly good impression of the morphology, despite the imperfect preservation in oolitic limestone and Parnes' photograph with very shallow incident light. One of the authors (GG) was able to examine this original material in the collections in Jerusalem.

The holotype cranidium is preserved as part and counterpart, with the positive being an internal mould. The counterpart has some portions of the recrystallized shell and steinkern adhering to the exterior suface. The cranidium is fairly small and has a long, tapering glabella, the frontal lobe of which reaches the anterior border furrow. The glabellar furrows appear to be directed backward, with S3 not clearly visible. The occipital furrow is transglabellar. The occipital ring carries a median node.

Palpebral lobes are long, their posterior tips reaching or nearly reaching the posterior border furrow; gently arched, defined by a distinct palpebral furrow, projecting into fairly short, oblique eye ridges. Fixigenae comparatively narrow (tr.), about $60 \%$ of maximum glabellar width, traversed by a shallow and broad, slightly curved depression, which creates a slightly raised proximal portion close to the axial furrows and a less raised narrow lunar ridge close to the palpebral furrows.

Preocular areas of exsagittal are narrow, sloping anteriorly. Anterior border furrow a distinct groove. Anterior border narrow, distinctly raised to form a brim-like structure.

DISCUSSION: Timnaella? orientalis (Picard, 1942), originally described as a species of the formerly collective genus Protolenus Matthew, 1887b, is clearly distinguished from that genus by numerous characters, most of all the different type of glabella (see Geyer $1990 \mathrm{~b}$ and Westrop and Landing 2000, for detailed description of Protolenus). Parnes (1971) transferred the species to Resserops (Richterops), which is now treated as Perrector (Richterops). Indeed, the cranidium is quite reminiscent of species of this subgenus, but the similarities are superficial and of little taxonomic significance. The genus and subgenus includes fairly large redlichioid trilobites with a long thorax and at least one macropleural segment as well as a pygidium of comparable size to the cranidium. In all of the species, the anterior border is quite broad (sag.) and bar-like because it overlies a distinct rostral plate, to which the hypostome is attached (see holotype of Perrector (Richterops) falloti (Hupé, 1953) in Hupé 1953a or Chang et al. 1997, fig. 293.3). In addition, the palpebral lobes in the Resseropinae are relatively broad and have a distinct adaxial curvature close to the posterior tips, 
and a transverse depression of the type seen in Timnaella? orientalis is also unknown among the Resseropinae.

Rushton and Powell (1998) placed the species tentatively under Realaspis, emphasizing the similarity of the palpebral lobes, and also noted some resemblance to Hesa problematica.

The species cannot be assigned to any known genus with certainty. The visible characters show a fairly good match with those seen in Timnaella eyali and T. wingi, despite the differences in preservation. Fundamental differences can be seen in the quite narrow (sag.) anterior border, the apparently quite prominent anterior border and the narrower fixigenae with a more clearly developed depression. Timnaella eyali has a similarly narrow anterior border, which appears to be less upturned, a less clearly tapering glabella, and wider fixigenae with a better developed exsagittal convexity. In addition, the connection of the palpebral lobes with the eye ridges shows a small angular change. Timnaella wingi has wider fixigenae and a broader preglabellar depression. Imperfectly preserved material of immature cranidia figured by Parnes (1971, pl. 1, figs. 10, 11) as Strenuella $(S$.$) sp. 2$ possible represents the same species.

Timnaella? cf. orientalis (Picard, 1942)

(Text-figs 9.4, 9.5, 9.8-9.10)

MATERIAL: Approximately 7 cranidia, reposited under FG-602-007a, FG-602-014b, FG-602-023, FG602-24b, FG-602-051b. All from the Wadi Uhaymir section, Jordan.

DESCRIPTION: Cranidium with width/length ratio c. 0.75. Anterior margin gently curved, with median arcuation. Palpebral lobes extending beyond tips of anterior sections of facial suture. Glabella length c. $80 \%$ of cranidial length in adult individuals (up to more than $90 \%$ in immature individuals) and c. half cranidial width across occipital ring in adult individuals (c. $40 \%$ in immature individuals); tapering slightly forward, with approximately straight sides; frontal lobe with shallow arcuation in dorsal view; glabella moderately convex, with tendency to form a median longitudinal ridge in transverse section. Three pairs of lateral glabellar furrows, all of them shallow; S1 moderately long, rearwardly curved; S2 moderately long, thin furrow more-or-less normal to axis; S3 very short and at the anterolateral corners of glabella. Occipital furrow consisting of moderately well impressed, faintly arcuate lateral furrows with a tendency to bifurcate; median section obsolescent. Occipital ring length sagittally up to c. $15 \%$ of cephalic length, with moderately curved posterior margin and subterminal node (imperfectly preserved on the specimens).

Axial furrows varying in depth, usually moderately deep and moderately wide. Fixigenae composed of slightly convex crescentic portions adjacent to axial furrows and to palpebral furrows, separated by shallow and weakly defined slightly curved longitudinal depression; width across centre of palpebral lobes up to threequarters maximum width of occipital ring; exsag. length next to axial furrows c. $45-50 \%$ of cephalic length.

Palpebral lobes moderately long, c. $40 \%$ of cephalic length in adult specimens (up to c. $48 \%$ in immature individuals), gently curved at ocular suture, about equal in transverse width throughout, transversely convex, but more strongly sloping toward palpebral furrow; anterior tips at level of S2 in adult specimens, up to level of S3 in young individuals; posterior tips at anterior level of occipital ring, short distance from posterior border. Palpebral furrows moderately well developed. Eye ridges project from the anterior ends of palpebral lobes obliquely forward, delimited from palpebral lobes by a shallow transverse depression, relatively short; develop into two faint projections at axial furrow of which the posterior thread appears to be faintly connected with anteriormost part of L3 at anterolateral corners of the glabella, the anterior thread develops into a low indistinct parafrontal band, which is well separated from the frontal lobe.

Anterior branches of the cephalic suture not well preserved, clearly diverging from anterior ends of ocular suture, curve inward at anterior border furrow to clip off a considerable part of the anterior border. Posterior branches not preserved, short.

Preglabellar field sagittally very narrow to absent. Preocular fields narrow, slightly convex areas sloping ventrally from eye ridges. Anterior border clearly convex, well defined in small individuals, less so with growing size, length sagittally c. 5-8\% cephalic length. Anterior border furrow well defined in front of preocular areas, merely a change in convexity in front of glabella. Posterior border with low to moderate convexity, with double curvature from axial furrows, sloping ventrally posterior to palpebral lobes. Posterior border furrow a shallow groove, poorly delimited from fixigenae.

Librigena known only from immature, imperfectly preserved specimens. Extraocular area narrow. Lateral margin fairly weakly curved. Lateral border convex, extended into a long genal spine along ocular suture. Posterior margin of librigena broad (tr.), forms an acute angle with adaxial margin of genal spine.

Thorax and pygidium not known with certainty. 
Surface of the cranidium in adult specimens covered by small granules except for glabellar furrows, axial furrows, and palpebral lobes. Small individuals smooth.
DISCUSSION: The material described above probably represents the species described as Protolenus orientalis by Picard (1942) (see discussion above).
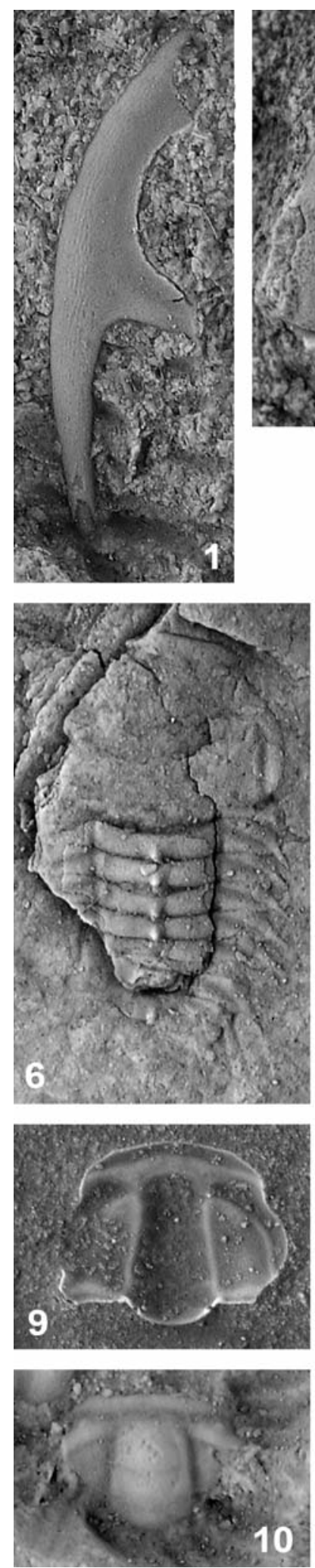
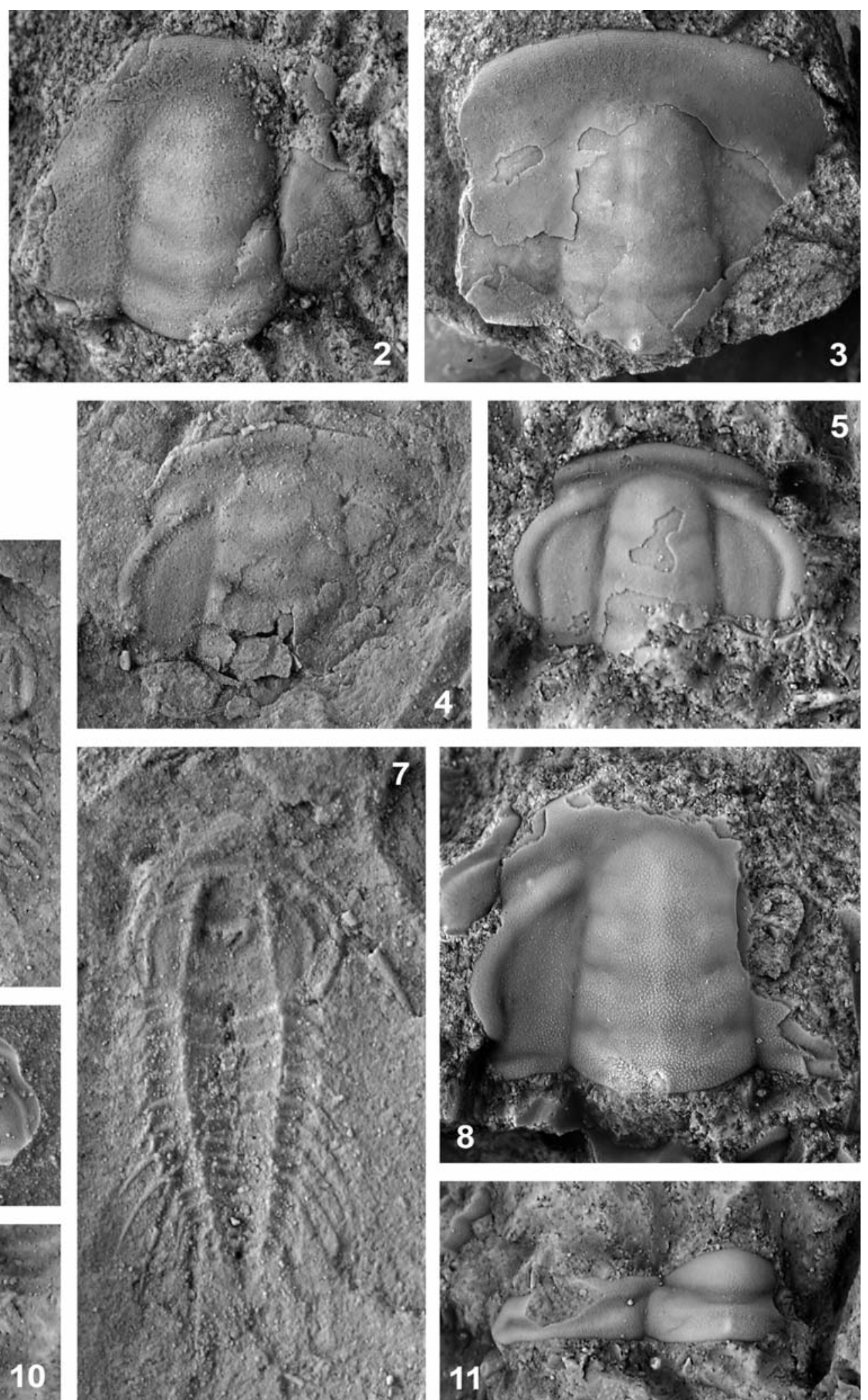
The type material from Israel, however, is imperfectly preserved in a way that does not allow the well preserved material from the Wadi Uhaymir section to be placed with certainty under the same species.

Subfamily Ellipsocephalinae Matthew, 1887

Issalia gen. nov.

TYPE SPECIES: Issalia scutalis gen. nov., sp. nov.

ETYMOLOGY: Named after the Wadi Issal area, Jordan, in which the type material was collected.

DIAGNOSIS: Genus of the Subfamily Ellipsocephalinae with glabella c. $80 \%$ cephalic length, tapering forward, frontal lobe moderately wide, subtruncate; three pairs of weakly impressed, roughly parallel and progressively less well developed lateral glabellar furrows; fixigenae weakly convex, with faint oblique depression; palpebral lobes long, reaching toward posterior border furrow, separated from eye ridges by weak depression; eye ridges meet dorsal furrows at level of S3; preglabellar field, preocular areas and anterior border fused to form a wide platform with the anterior border slightly raised toward the anterior margin.

DISCUSSION: Issalia gen. nov. is a typical genus of the Ellipsocephalinae, with the basic pattern of three pairs of lateral glabellar furrows, a slightly tapering glabella, long palpebral furrows which are slightly arched against the eye ridges, and inconspicuously subdivided fixigenae. These characters create the impression that the type species could be grouped among trilobites dealt with under classic genera such as Lusatiops Richter and Richter, 1941, Pseudolenus Hupé, 1953a, Latoucheia Hupé, 1953a, Proampyx Frech, 1897 or Comluella Hupé, 1953a. However, careful examination of this notoriously difficult group has shown that morphoclines towards a progressive smoothing occurred independently at least twice in the traditional late Early to early Middle Cambrian (Geyer 1990b) and that the distinction of exterior morphology from internal moulds as well as the longitudinal morphology across the eye ridges are crucial issues. In this context, Issalia does not belong to the ellipsocephaloid-kingaspidoid clade, as clearly indicated by the morphology of the frontal lobe, being slightly narrower (tr.) than L3 and with subrounded to obliquely truncated anterolateral corners. A major feature that distinguishes Issalia from other nonellipsocephaloid-kingaspidoid trilobites is the platformor brim-like anterior part of the cranidium composed of the superficially fused preglabellar field, preocular areas and anterior border, with the anterior border weakly raised towards the anterior.

Issalia gen. nov. resembles the Moroccan genus Planolimbus Geyer, 1990b from the lower Middle Cambrian of the Anti-Atlas Mountains. However, it clearly derives from kingaspidoid ancestors and can be distinguished easily from the latter by a number of relevant characters, primarily the pattern of strongly arched lateral glabellar furrows. A closer systematic affinity appears to exist to Timnaella Parnes, 1971, as illustrated by T. eyali Parnes, 1971 . However, the genera are easily distinguished by the almost subtruncate glabella and the low convexity of the anterior cranidial region in Issalia.

Issalia scutalis gen. nov., sp. nov. (Text-fig. 9.1-9.3)

ETYMOLOGY: From the Latin scutum, shield; a reference to the unit resulting from the fused preglabellar field, preocular areas and anterior border and to the low overall convexity of the cranidium.

HOLOTYPE: Incomplete cranidium, FG-602-095a.

PARATYPES: Incomplete cranidium, FG-602-107, and single librigena, FG-602-080. All material from Wadi Issal, Jordan.

DESCRIPTION: Cranidium with width/length ratio of about 0.8 . Anterior margin gently curved. Palpebral lobes slightly extending beyond tips of anterior sections of facial suture. Glabella c. $80 \%$ cranidial length and c. $45 \%$ cranidial width across occipital ring; slightly tapering forward, with approximately straight sides; frontal lobe about one-third maximum cranidial width, with semitruncate anterior margin; glabella moderately con-

Text-fig. 9. 1-3, Issalia scutalis gen. nov., sp. nov.; all specimens from the Wadi Issal section. 1 - FG-602-080, librigena, dorsal view, $\times$ 8; $2-$ FG-602-95a, immature cranidium, dorsal view, $\times 6$; 3 - FG-602-107, cranidium, dorsal view, × 4. 4, 5, 8-10, Timnaella? cf. orientalis (Picard, 1942); all specimens from the Wadi Uhaymir section. 4 - FG-602-014b, cranidium, dorsal view, × 6; 5-FG-602-007a, cranidium, dorsal view, $\times 8$; 8-FG-602-024b, incomplete cranidium, dorsal view, $\times 6$; 9 - FG-602-023, cranidium of immature individual, ventral view, $\times 9$; $10-$ FG-602-051b, cranidium of immature individual, ventral view, $\times 9.6$, 7, Myopsolenites cf. hyperion sp. nov.; from the Wadi Uhaymir section. 6-FG-602-049a, incomplete cranidium and partial thorax of immature individual, dorsal view, $\times 9$; 7 - FG-602014a, nearly complete dorsal carapace of late meraspid individual, dorsal view, $\times 9.11$ - Tayanaspis bulbosus gen. nov., sp. nov., Wadi Uhaymir section, FG-602-009b, partial thoracic segment, dorsal view, $\times 8$. 
vex, with tendency to have a median arcuation anteriorly in transverse section. Three pairs of lateral glabellar furrows, all of them shallow to moderately well impressed; S1 and S2 moderately rearward directed and fairly long, separated at short distance over the midline; S3 a short depression close to the axial furrows. Occipital furrow moderately well impressed and moderately wide, with a faint median section. Occipital ring sagittally up to $20 \%$ cephalic length, with a moderately curved posterior margin and a probably short subterminal spine (only imperfectly preserved on the specimens).

Axial furrows varying from shallow next to proximal areas of fixigenae to moderately deep between eye ridges and glabella. Fixigenae with small bacculae on posteroproximal portions and weakly raised distal portions paralleling palpebral lobes, separated by shallow and weakly defined longitudinal depression; width across centre of palpebral lobes half maximum width of occipital ring; exsag. length next to axial furrows in the order of $40 \%$ cephalic length.

Palpebral lobes moderately long (c. $40 \%$ cephalic length), gently curved at ocular suture, transverse width about equal throughout, with distinct transverse convexity; anterior ends at level of S3 or slightly behind, posterior tips at mid level of occipital ring, almost reaching posterior border. Palpebral furrows moderately well developed. Eye ridges project obliquely forward from anterior ends of palpebral lobes, delimited from palpebral lobes by a shallow transverse depression, swing forward as low, poorly defined ridges; posterior section of eye ridges transverses axial furrows as a low swelling to meet anteriormost part of L3.

Anterior branches of the cephalic suture not well preserved, but clearly diverging from anterior ends of ocular suture, curve inward at anterior border furrow to clip off a considerable part of the anterior border. Posterior branches not preserved, short.

Preglabellar field a sagittally narrow area, grading into the anterior border without a clear definition. Preocular fields moderately wide, slightly convex areas sloping ventrally from eye ridges.

Anterior border a low, slightly convex area, length sagittally c. $5 \%$ cephalic length. Anterior border furrow a comparatively broad, poorly defined depression. Posterior border convex, apparently more-or-less straight throughout. Posterior border furrow a quite shallow groove, poorly defined from fixigenae.

Librigena with very narrow extraocular area, which is narrower (tr.) than adjacent part of lateral border. Lateral border slightly convex, poorly delimited from border furrow, extends into a fairly long genal spine (about as long as the anterior part of the librigena). Anterior section of facial suture in accordance to that of the cranidium, swings adaxially at border furrow to describe a considerable curvature. Posterior section of facial suture short, almost straight and almost normal to axis. Narrow eye socle along ocular suture.

Thorax, and pygidium unknown.

Surface of the cranidium smooth except for small terrace ridges on anterior border. Preglabellar field and preocular areas traversed by faint caeca originating from eye ridges and arranged in a "centrifugal", pseudopalmate pattern. Librigena smooth on extraocular area, with fine terrace ridges on lateral border.

DISCUSSION: See discussion under genus.

Tayanaspis gen. nov.

TYPE SPECIES: Tayanaspis bulbosus gen. nov., sp. nov., by monotypy.

ETYMOLOGY: After Wadi Tayan, Jordan, where most of the present material was collected.

DIAGNOSIS: Genus of the Subfamily Ellipsocephalinae with glabella moderately long, tapering forward, frontal lobe narrow; fixigenae sublongitudinally divided by arched furrow, with adaxial part conspicuously swollen in adult individuals, abaxial portion faintly convex; palpebral lobes and eye ridges fused to form arched lobe, fused with frontal lobe and with branch proceeding into parafrontal band; preglabellar field and preocular areas forming continuous groove; anterior border more-or-less equally curved convex brim.

DISCUSSION: Rushton and Powell (1998, p. 139) had a limited amount of material of the type species of this new genus and assigned it to the genus Realaspis Sdzuy, 1961 without referring to a described species or introducing a new species. In their discussion, they particularly emphasized the "broad interocular area of the fixigenae and the short palpebral lobe" and also the morphological similarity of the pygidia with those of the Subfamily Metadoxidinae. These were taken as arguments for the placement of the species, albeit the authors were the first to suggest a placement of Realaspis under the Metadoxidinae. In addition, Rushton and Powell (1998) stressed the similarity of the cranidium with that of Realaspis strenoides Sdzuy, 1961, the type species of Realaspis, but emphasized marked differences. Among the differential characters mentioned by Rushton and Powell (1998), particularly the absence of a swollen area on the fixigena and a rather moderate relief in the cranidium, are such obvious differences in the character set that a close similar- 
ity between the type species of Realaspis and the new species described here can be excluded.

In fact, Realaspis is based on poorly preserved material from the Sierra Morena region in southern Spain (Sdzuy 1961). The holotype, a distorted internal mould of a cranidium, does not allow recognition of the details of the exterior, with the glabella having lost nearly all furrows. What is recognizable, however, is that the palpebral lobes are much shorter than in the Jordanian material, distinctly oblique to the axis, broader than the low eye ridges, and located on a slight abaxial swelling of the fixigenae. Thus, the Spanish form is certainly not congeneric with the Jordanian one. A close phylogenetic relationship with Tayanaspis is at best indicated only by the similarity of the pygidium, albeit notable differences exist in the number of segments (as shown by the axial furrows) and the overall shape with fairly angular anterolateral corners in Realaspis. It should be mentioned that the late Klaus Sdzuy himself stated that he was unhappy with the taxon after having introduced it and conceded that the much retouched photos in the original publication did not give a realistic impression of the morphology of the type species (oral comm. to GG, November 1995). Additional species, which were later attributed to Realaspis, suffer from this same deficiency and, in fact, a morphologically fairly heterogenous assemblage of species has been included under this genus.

Despite the question of a close relationship between Tayanaspis and Realaspis, they are certainly not closely related with Metadoxides Bornemann, 1891, and thus are not members of the Subfamily Metadoxidinae. Metadoxides belongs to a small group of lower Cambrian trilobites characterized by a tapering glabella, fairly short palpebral lobes continuing into eye ridges which are broadly attached to the frontal lobe of the glabella, fairly wide (tr.) pleurae without much transverse convexity, and a mostly triangular pygidium continuing the rearward tapering of the posterior thorax. Only its taxa from Sardinia allow the Subfamily Metadoxidinae to be characterized with sufficient morphological criteria. As a consequence, most of the genera shown in the revised Treatise volume (Chang et al. 1997) appear to be wrongly placed. This accounts primarily for Onaraspis Öpik, 1968 (see discussion below under Bathynotidae), Churkinia Palmer, 1968, and Minusinella Repina, 1960 (in Khalfin 1960).

Tayanaspis bulbosus gen. nov., sp. nov. (Text-figs 9.11, 10 and 11)

1998. Realaspis sp. nov.; Rushton and Powell, p. 139-140, figs $15-18$.
MATERIAL: C. 80 cranidia, half of them of immature individuals on a few slabs, in repository: FG-602-013a, FG-602-015a, FG-602-019a, FG-602-019b, FG602-020a, FG-602-022, FG-602-026a, FG-602-032a, FG-602-035c-e, FG-602-035a, FG-602-035g-i, FG602-038c-f, FG-602-051a, FG-602-062g, FG-602074a; incomplete dorsal carapace, FG-602-042a; numerous partial thoracic segments, in repository: FG-602-009b, FG-602-042c; c. 8 pygidia, in repository: FG-602-001, FG-602-018b, FG-602-023, FG602-025a, FG-602-025d, FG-602-062f, FG-602077a, FG-602-077b. All specimens from the Wadi Uhaymir section, Jordan.

ETYMOLOGY: From the Latin bulbosus, bulbous, nodular; an allusion to the swollen part of the fixigenae.

DIAGNOSIS: As of the genus (because of monotypy).

DESCRIPTION OF ADULT MORPHOLOGY: Cranidium with width/length ratio of about 0.70 to 0.72 . Anterior margin gently curved. Palpebral lobes clearly extending beyond tips of the anterior sections of the facial suture, with anterior end of ocular furrows at about the distance of the anterolateral corners from midline.

Glabella about $80 \%$ cranidial length and 37 to $40 \%$ cranidial width across occipital ring; sides straight in smaller individuals and progressively curved in larger ones, progressively tapering forward, frontal lobe with fairly narrow curvature in dorsal view; posterior section of frontal lobe faintly expanded due to a fusion with the projections of the eye ridges, maximum width of frontal lobe c. $65 \%$ maximum width of maximum occipital width; glabella highly convex. Three pairs of lateral glabellar furrows, all of them faintly impressed on the exterior of the test; S1 and S2 moderately rearwardly directed and moderately long, clearly separated over midline; S3 slightly longer and even more steeply rearwardly directed, separated by short gap medially. Occipital furrow very shallow, best seen as shallow depressions adjacent to axial furrows, with a slight backward swing and an obsolescent median section. Occipital ring sagittally about 12 to $14 \%$ cephalic length, with a moderately curved posterior margin and a distinct and short (sub)terminal spine.

Axial furrows varying from deep next to raised proximal areas of fixigenae and inconspicuous around frontal lobe. Fixigenae divided into two strikingly different parts: proximal area highly raised, with straight proximal margin to axial furrows and curved distal margin, highest elevation next to $\mathrm{S}$; ; anterior termination subacute, posterior end rounded; distal area of fixigenae is a low platform with some inclination towards its pos- 

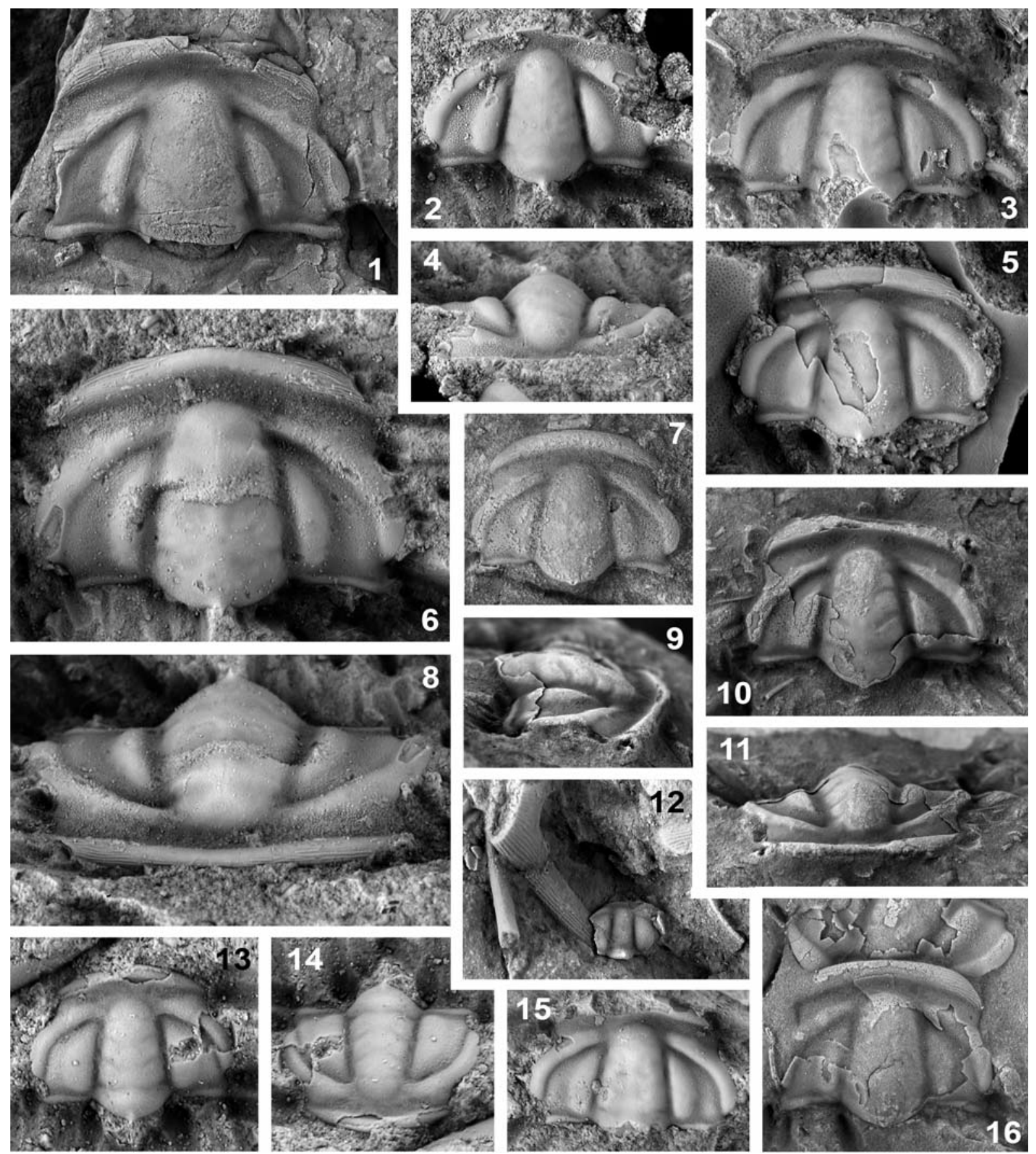

Text-fig. 10. 1-16 - Tayanaspis bulbosus sp. nov.; all specimens from the Wadi Uhaymir section. 1 - FG-602-035f, incomplete cranidium, dorsal view, $\times 3$; 2, 4 FG-602-022, immature incomplete cranidium, dorsal and anterior views, $\times 5$; 3 - FG-602-020a, incomplete cranidium, dorsal view, $\times 5$; 5 - FG-602-026a, cranidium, dorsal view, $\times$ 5; 6, 8-FG-602-032a, cranidium, partly exfoliated, dorsal and anterior views, $\times 5$; 7 -FG-602-015a, cranidium, dorsal view, $\times 3$; 9-11 - FG602-074a, cranidium, partly exfoliated, oblique right lateral, dorsal, and anterior views, $\times 3$; $12-$ FG-602-35, meraspid cranidium, dorsal view, $\times 6$; 13,14 - FG602-019a, immature cranidium, dorsal and oblique anterior views, $\times 8$; 15 - FG-602-034a, incomplete cranidium, internal mould, dorsal view, $\times 5 ; 16-$ FG-602-038a, FG-602-038b, cranidia, partly exfoliated, dorsal views, $\times 3$

Text-fig. 11. 1-17 - Tayanaspis bulbosus sp. nov.; all specimens from the Wadi Uhaymir section. 1,2-FG-602-009c, incomplete pygidium, dorsal and left lateral views, $\times 4 ; 3,5-$ FG-602-077a, pygidium, partly exfoliated, dorsal and posterior views, $\times 5 ; 4,6-$ FG-602-077b, pygidium, dorsal and right lateral views, $\times 5 ; 7-$ FG $-602-$ 042a; cranidium with fairly complete attached thoracic carcase, dorsal view, $\times 5.5 ; 8-$ FG-602-035b, FG-602-035c, FG-602-035d, incomplete cranidium, librigena, and pygidium, dorsal views, $\times 4.5 ; 9-$ FG-602-051a, cranidium, largely exfoliated, dorsal view, natural size; $10-$ FG-602-062g, immature cranidium, dorsal view, $\times 6$; 
CAMBRIAN TRILOBITES OF JORDAN
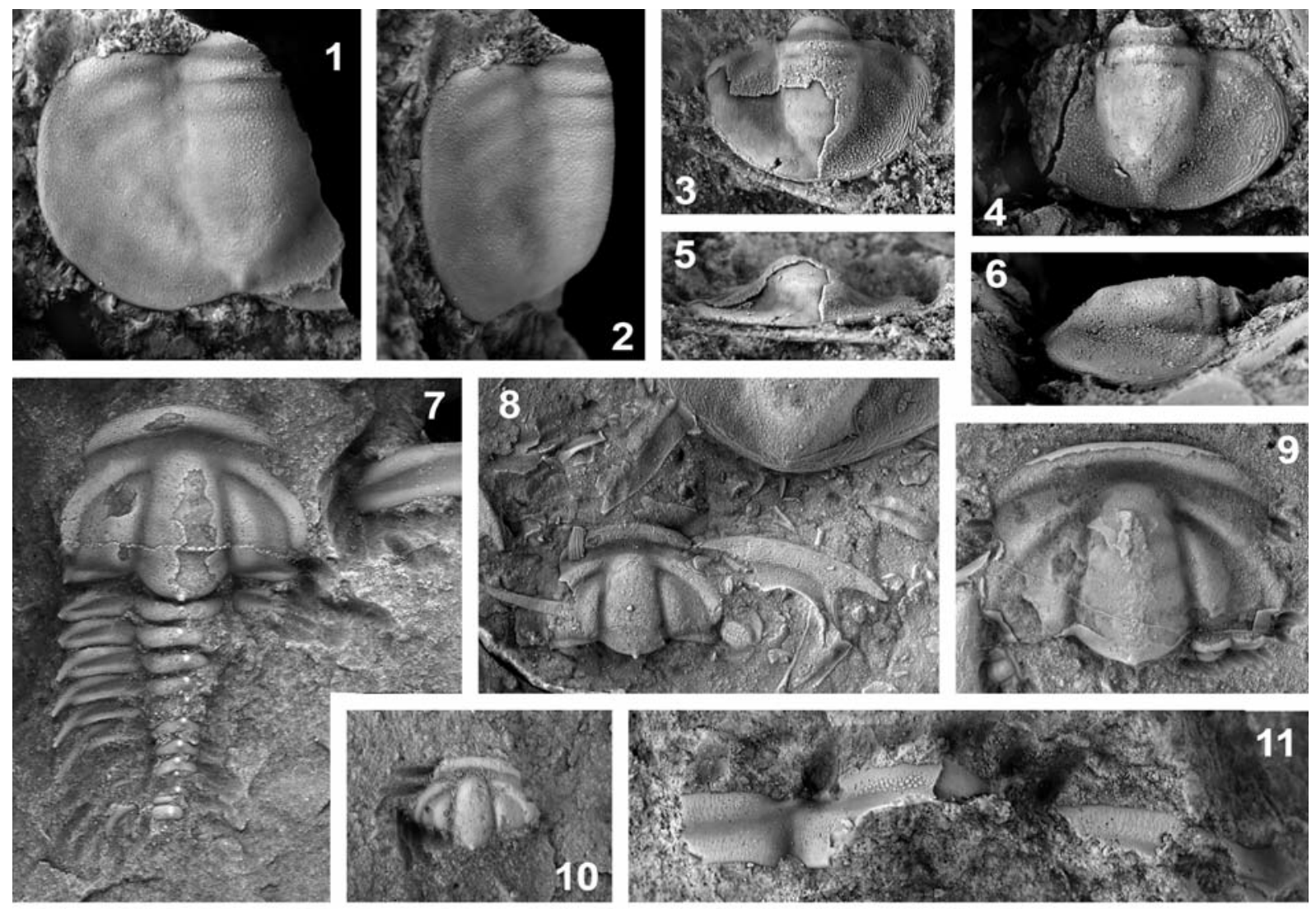

\section{7}
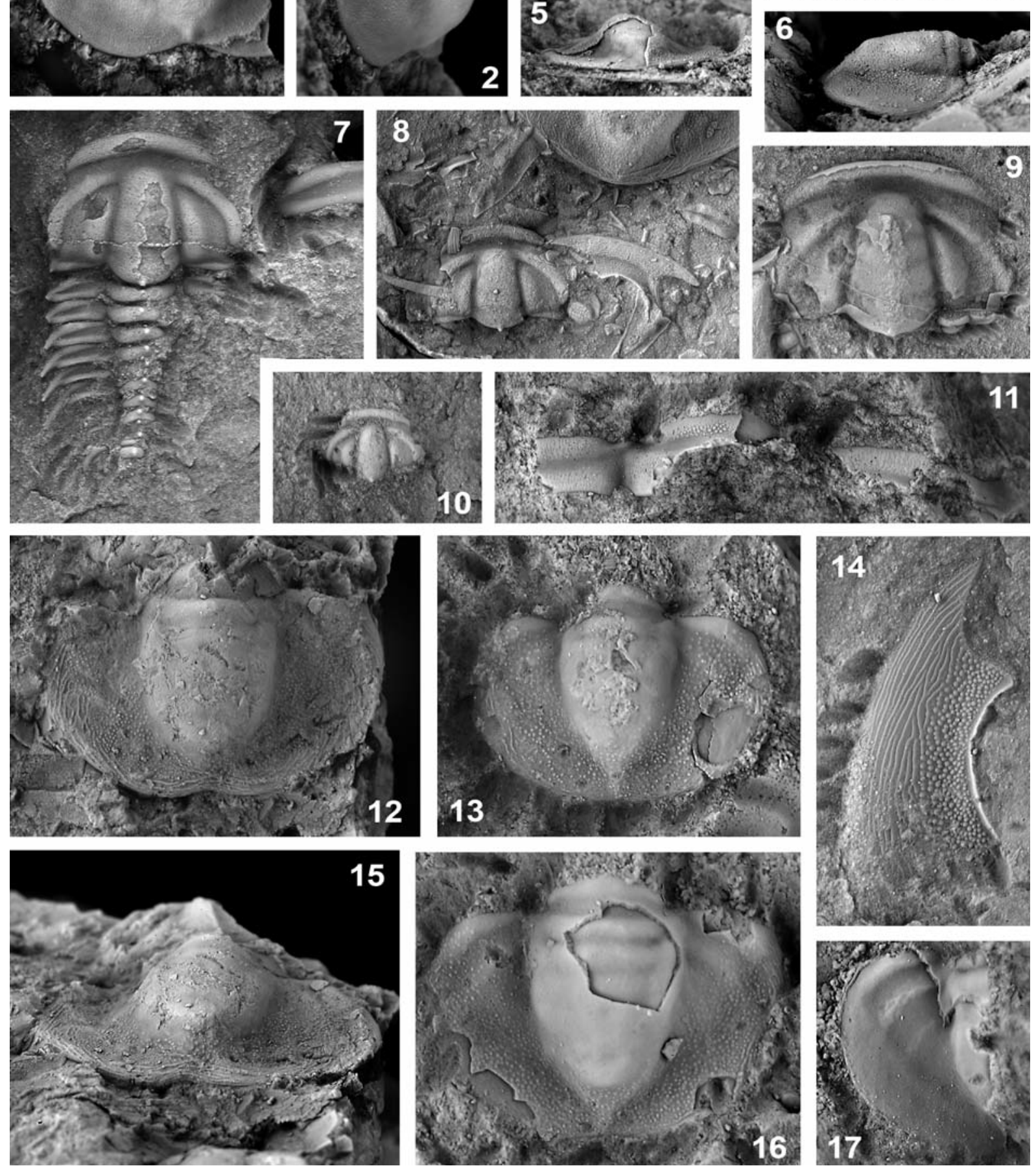

11 - FG-602-037a, fragment of thoracic segment, dorsal view, $\times 5 ; 12,15-$ FG-602-001, incomplete pygidium, dorsal and posterior views, $\times$ 4; 13 - FG-602-025d, pygidium, partly exfoliated, dorsal view, × 6; 14 - FG-602-057c, incomplete librigena, dorsal view, × 6; $16-$ FG-602-025a, pygidium, partly exfoliated, dorsal view, $\times 6$; $17-$ FG-602-018b, partial pygidium, internal mould, dorsal view, $\times 6$ 
terior rim, forming very low bacculae-type swellings close to the posterior tips of the palpebral lobes; extending across centre of palpebral lobes to c. $60 \%$ maximum width of occipital ring; exsag. of about onethird cephalic length next to axial furrows.

Palpebral lobes gently curved at ocular suture, slightly reduced in width towards anterior and posterior tips, generally with moderate transverse convexity, distal portions tend to be more raised towards the posterior, with about equal elevation throughout; breadth 22 to $24 \%$ of maximum occipital width, exsagittal length about $25 \%$ cranidial length; anterior ends at level of S3, posterior tips at about level of occipital furrow, separated by short distance from posterior border. Palpebral furrows shallow, weakly defined topographically but distinguished from distal area of fixigenae by lack of granules. Eye ridges project from palpebral lobes, together forming a fairly homogeneous arc, slightly narrower and progressively less elevated to fade towards axial furrows; roughly three times longer than wide; anterior section of eye ridges swings forward next to glabella to project into a shallow lobe that surrounds the frontal lobe of the glabella, barely recognizable in width and elevation anterior to glabellar front on the exterior of the test.

Anterior branches of facial suture diverge moderately strongly from anterior ends of visual surface and swing medially in a gentle curvature in the anterior third of the preocular field to cut anterior border at a distinctly oblique angle. Posterior branches fairly short, forming a gentle curve, but only slightly diverging in ventral view because of a strong ventral deflection, with lateral tips of posterior border extending to nearly the level of the palpebral lobes' maximum distance from midline.

Preglabellar field sagittally narrow, only c. $3 \%$ cephalic length, developed as a concave groove in sagittal section, with faint median plectrum. Preocular fields slightly concave, sloping ventrally in the distal onethird.

Anterior border highly convex, sagittal length c. $10 \%$ cephalic length, defined posteriorly by relatively steep slope towards border furrow. Anterior border furrow developed only as a steep slope. Posterior border convex, weakly sigmoidal, of more-or-less equal breadth throughout, but with highest elevation posterior to distal one-third of fixigenae. Posterior border furrow fairly shallow, poorly defined anteriorly.

Librigena with narrow extraocular area, about as wide as or slightly wider (tr.) than adjacent part of lateral border. Lateral border extends into a moderately long genal spine (shorter than the anterior part of the librigena). Anterior and posterior sections of facial suture in accordance to that of the cranidium. Narrow eye socle along ocular suture. Lateral border and genal spine with longitudinal to fairly oblique terrace lines. Doublure completely underlies borders.

Thorax not known from a complete adult, of at least 12 segments. Axial rings strongly convex in transverse section. Median portion sagittally convex, with distinct, prominent median node. Anterior margin of axial ring generally straight or slightly sigmoidal, but with distinct rearward bend in segment 1 . Posterior margin generally straight, with a distinct forward curvature toward axial furrows.

Pleurae with anterior margin straight and more-orless normal to axis up to a stout fulcral process about three-fifths the distance between dorsal furrows and pleural tips, curving rearward abaxially to the fulcral process. Anterolateral portion forms strongly deflected facet abaxial to fulcral socket. Posterior margin of pleurae slightly curved, distal portion with slight forward swing to form shallow concave area at the base of the pleural spine, with small dorsoventral flexure about two-thirds the distance between dorsal furrow and pleural tip that forms an indistinct socket corresponding to the fulcral process of the adjacent tergite. Except for tergite 1 , fulcral sockets and corresponding processes are in a progressively adaxial position in posterior tergites. Pleural furrows well impressed, well defined, widest close to axial furrows, progressively decreasing abaxially to form slender, slightly curved triangular areas; abaxial tip slightly distant from base of pleural spine. Pleural tip formed by a posterior curvature of the anterolateral margin, producing a fairly long, obliquely directed pleural spine that grows progressively rearward. Pleurae of first tergite slightly modified, with short abaxial portions terminated by fulcral processes corresponding to cephalic posterior border. Abaxial part of pleurae at first thoracic tergite with strong deflection of a moderately large facet.

Pygidia from the same beds as the cranidia are assigned to the same taxon. These pygidia have comparatively strongly curved anterior and posterior rims. The length/width ratio is usually slightly less than 1.0. The highly convex axis is stout and tapers rearwards. It has a length of about 83 to $85 \%$ of the pygidial length. Its terminal axial piece is well rounded. Apart from the sagittally very narrow articulating half-ring, one axial ring is defined by a clearly visible furrow, an additional axial furrow faintly impressed. The width of the axis is less than one third of the pygidial width. The highly convex pleural fields have three pairs of interpleural furrows. A very shallow plectrum between terminal axial piece and posterior border counterfeits an additional pair of interpleural furrows. Pleural furrows are lacking. 
The border furrow is shallow and weakly delimited. It becomes slightly deeper where it joins the interpleural furrows. The border is low, its surface broad and weakly convex. Behind the posterior axial piece the border has a weak indenture or at least a straight, clipped portion.

Surface of the cranidium with different types of ornamentation/prosopon. Highly elevated parts of glabella, palpebral lobes, and proximal areas of fixigenae smooth; lateral parts of glabella, distal areas of fixigenae, posterior border and border furrow, preglabellar field and preocular areas densely covered with fine to medium-sized granules. Distal and medial part of anterior border carries well developed terrace lines roughly parallel to the anterior margin. Thoracic axial rings and pleura (except for smooth pleural furrow) covered with granules, pleural spines with terrace ridges (Text-fig. 11.11).

ONTOGENY: Tayanaspis bulbosus gen. nov., sp. nov. shows a striking ontogenetic development, which is mainly created by a change of the fixigenal morphology and, less clearly, of the glabella and the anterior border. Starting at meraspids with normal, distinctly convex fixigenae (Text-figs 10.12, 10.13), there is a tendency during individual development to reduce the convex genae to narrow, lenticular bulbous lobes close to the dorsal furrows, whereas the rest of the fixigenae forms a nearly flat platform or even develops weakly convex lobes adjacent to the palpebral furrows (Text-fig. 10.8). In early meraspids, the glabella is nearly parallel-sided and with a distinct occipital ring (Text-fig. 10.12; no occipital node!). It becomes progressively more tapered with a rounded frontal lobe. Fully grown adult specimens have a tapering glabella with slightly curved sides and a somewhat flattened frontal lobe with subangular anterolateral corners (Text-fig. 10.6). The anterior border starts as an inconspicuous, relatively narrow (sag.) blade and grows in breadth during growth. It finally develops a faint kink in front of the glabella. Palpebral lobes and eye ridges form subevenly homogeneous, subequally curved, highly convex lobes of subequal width (Text-fig. 10.14) early in the ontogenetic series. However, the eye ridges become progressively narrower than the palpebral lobes in large individuals (Textfig. 10.6, 10.7).

Interestingly, the small holaspid specimen FG-602042a shows a small but distinct remnant of an intergenal spine (Text-fig. 10.7).

The Wadi Uhaymir locality yielded a number of small complete specimens preserved as external moulds in silty shale. Because of preservational reasons, details are often difficult to recognize. Nevertheless, the number of thoracic segments in these late meraspid to earliest holaspid specimens appears to be constantly 11 or
12. Text-fig. 11.7 shows a typical specimen with the pleural spines growing progressively in length rearward to attain a length of several times the length of the rest of the pleura in the posterior half of the thorax and with a progressive rearward direction. Further noteworthy is the extreme forward curvature of the extended posterior border so that the genal angle in this specimen is opposite L2 and includes an acute angle.

DISCUSSION: The most conspicuous character of Tayanaspis orientalis is the pronounced swelling on the fixigenae. Rushton and Powell (1998) referred to line-drawings of an as yet undescribed bigotinid species presented by Sdzuy (1978) from about the lowermost trilobite-bearing strata of the Moroccan Atlas ranges. This material has only superficial similarity, being minute, micropygid and having a quite different type of glabella. Much more worthy of comparison are the Moroccan ellipsocephaloid genera from the latest early Cambrian/late Banian Sectigena Zone of Morocco, such as Sectigena Geyer, 1990b or Termierella Hupé, 1953a. Both share with Tayanaspis the distinct swelling on the fixigenae, but have additional swollen areas adjacent to the palpebral lobes and the anterior border. Remarkably, similar genera with swollen portions of the fixigenae lived contemporaneously on other Cambrian continents, such as Chorbusulina Lazarenko, 1962 and Charaulaspis Lazarenko, 1962. However, all of these genera are obviously micropygid and probably represent a convergent morphological evolution.

Hesa Richter and Richter, 1941

TYPE SPECIES: Hesa problematica Richter and Richter, 1941, by original designation.

\section{Hesa problematica Richter and Richter, 1941}

DISCUSSION: Richter and Richter (1941, p. 18-19, figs 7-11) described and figured fragmentary trilobite material on which they based a new genus and species termed Hesa problematica. This material included a fragment of a large cranidium, an incomplete librigena, and fragmentary thoracic segments. The material, all collected by Blanckenhorn in 1908, came from the mysterious "Chirbet el-Bursch" locality and was partly referred to as fragments of Paradoxides by Blanckenhorn and Schmidt (see Blanckenhorn 1912, p. 411 and 412, respectively). The Richters designated the fragmentary cranidium as the holotype. This specimens preserves only slightly more than the frontal lobe of the glabella, part of the eye 
ridge, the preglabellar field and part of the preocular areas and anterior border. Investigation of the type material suggests that the reconstruction by Richter and Richter (1941, pl. 2, fig. 9) is incorrect. The Richters (1941, p. 19) referred to the fragment of a posterior part of a glabella which was not figured but present in the repository. They noted that all parts show a distinct granulation, including the occipital furrow. In fact, the well impressed parts of the occipital furrow are devoid of granules, and the different parts show some variation in the size and density of the granulation. It appears that the main reason for assigning the different sclerites like parts of a puzzle to the same species was based on the granulation and their large size.

In fact, the holotype is too insufficiently preserved to be useful for defining a taxon. The other sclerites almost certainly do not belong to the same species and were erroneously assigned to Hesa problematica. It is therefore suggested herewith to restrict Hesa problematica to its holotype. The holotype was re-illustrated by Rushton and Powell (1998, fig. 14).

\section{Kingaspis Kobayashi, 1935}

TYPE SPECIES: Anomocare campbelli King, 1923; by original designation.

Kingaspis campbelli (King, 1923)

(Text-fig. 12)

1923. Anomocare campbelli; King, p. 511, figs 2, 3.

1935. Kingaspis campelli [sic] (King); Kobayashi, p. 196, 305, pl. 23, figs 9,10

v 1941. Palaeolenus campbelli King [sic]; Richter and Richter, p. 19-20, pl. 2, figs 12-16.

1941. Anomocare campbelli King; Picard, p. 3.

1953. Kingaspis campbelli (King); Hupé, text-fig. 63A. non 1953. Kingaspis campbelli (King); Hupé, p. 254, pl. 9, figs 1-3.

v 1971. Kingaspis campbelli (King); Parnes, p. 201-202, pl. 2, figs 28, 29.
1976. Kingaspis campbelli; Cooper, p. 273.

1989. Kingaspis campbelli (King); Gil Cid and Jago, p. 93-94.

v 1990. Kingaspis campbelli (King 1923); Geyer, p. 104105 , pl. 15, fig. 11, pl. 17, figs 8-10.

1998. Kingaspis campbelli (King, 1923); Rushton and Powell, p. 141, figs 21-26.

non 1999. Kingaspis campbelli (King 1923); Dies et al., p. 221, 222, figs 1, 2 .

2001. Kingaspis campbelli (King, 1923); Geyer and Landing, p. 122.

non 2004. Kingaspis campbelli (King, 1923); Dies et al., p. 284.

2004. Kingaspis campbelli (King, 1923); Geyer and Landing, p. 9, 15-16, 19.

non 2004. Kingaspis campbelli; Liñán et al., p. 35.

v 2007. Kingaspis campbelli (King, 1923); Shinaq and Elicki, p. 255, 256, 261, 263, fig. 7.3, 7.4.

2007. Kingaspis (Kingaspis) campbelli (King, 1923); Gozalo et al., p. 366.

non 2007. Kingaspis (Kingaspis) campbelli (King, 1923); Gozalo et al., p. 364, 365, 367, figs 4A, 5F.

2007. Kingaspis campbelli (King, 1923); Dies Álvarez et al., p. 420, 426.

non 2008. Kingaspis (K.) campbelli; Gozalo et al., p. 143.

non 2008. Kingaspis (Kingaspis) campbelli King, 1923; Liñán et al., p. 12, 16, 28, 34, 36, figs 4, 12, 15, 17.

2009. Kingaspis campbelli (King, 1923); Żylińska and Szczepanik, p. 421, 423.

non 2011. Kingaspis campbelli; García-Bellido et al., p. 646, 648.

2011. Kingaspis (Kingaspis) campbelli; Gil Cid et al., p. $54,55,56$.

MATERIAL: C. 90 cranidia, reposited: FG-602-031a, FG-602-047b-d FG-602-047f, FG-602-048a, FG602-079, FG-602-083a, FG-602-093b, FG-602101a, FG-602-101d-f, FG-602-102a; 8 librigenae, reposited: FG-602-094, FG-602-101b; numerous incomplete thoracic segments, reposited: FG-602-037a, FG-602-047e, FG-602-099b, FG-602-101c, FG602-106a-c. All specimens from the Wadi Zerqa Ma' in locality.

Text-fig. 12. 1-24 - Kingaspis campbelli (King, 1923); all specimens from the Wadi Zerqa Ma'in locality. 1, 2 - FG-602-048a, largely exfoliated cranidium, dorsal and left lateral views, × 2,5; 3, 7 - FG-602-093a, FG-602-093b, large shelled and small, largely exfoliated cranidia, $\times 2.5$; 3, dorsal views of both specimens; 7, anterior view of large cranidium; 4, 5, 8 - FG-602-083a, cranidium, dorsal, right lateral and posterior views, $\times 3$; 6 - FG-602-094, incomplete librigena, ventral view showing broad doublure, $\times 3 ; 9,10,16-$ FG-602-102a, incomplete cranidium, internal mould, $\times 3$; $11-$ FG-602-101c, incomplete thoracic segment, $\times 4.5$; 12, 17 - FG-602-047b, immature cranidium, dorsal and left lateral views, $\times 4$; $13-$ FG-602-099b, librigena, dorsal view, $\times 4$; $14-$ FG-602-047f, juvenile cranidium, dorsal view, $\times 6$; $15-$ FG-602-101b, librigena of adult specimen showing roughly straight lateral margin, dorsal view, $\times 3$; 18 - FG-602-031a, immature partial cranidium, partly exfoliated, showing caecal pattern internal mould of preglabellar field, dorsal view, $\times 4$; 19, 20, 24 - FG-602-079, cranidium, internal mould, specimen figured by Shinaq and Elicki (2007, fig. 6.4), anterior, left lateral and dorsal views, $\times 3$; $21-$ FG-602-047e, thoracic segment, largely exfoliated, dorsal view, $\times 3 ; 22-$ FG-602-093b, incomplete immature cranidium, largely exfoliated, dorsal view. Note small impression on frontal area resulting from ventral swelling of shell, probably created by parasitic activity, $\times 4.5 ; 23-$ FG-602-101a, cranidium, largely exfoliated, dorsal view, $\times 3$ 

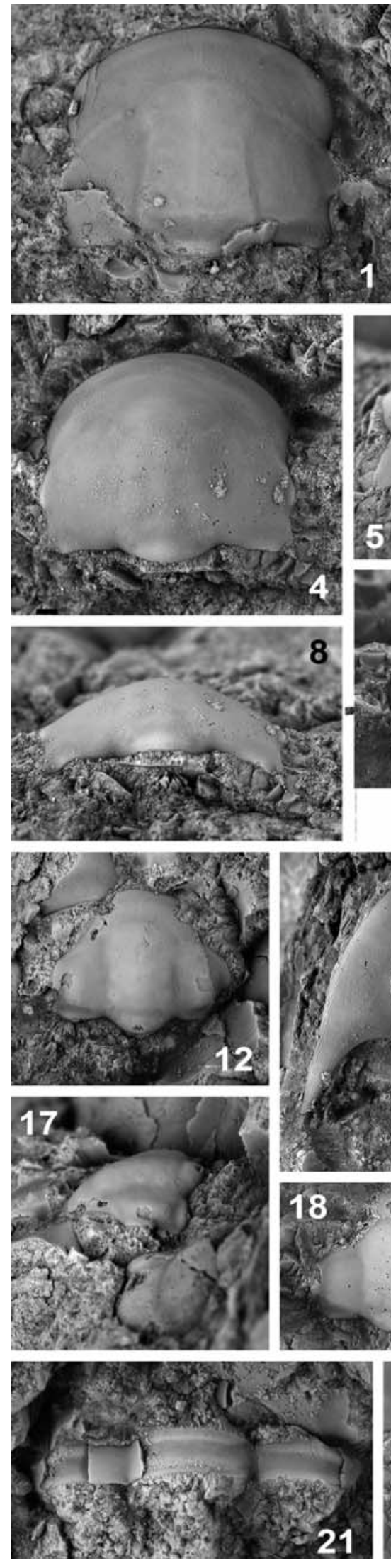
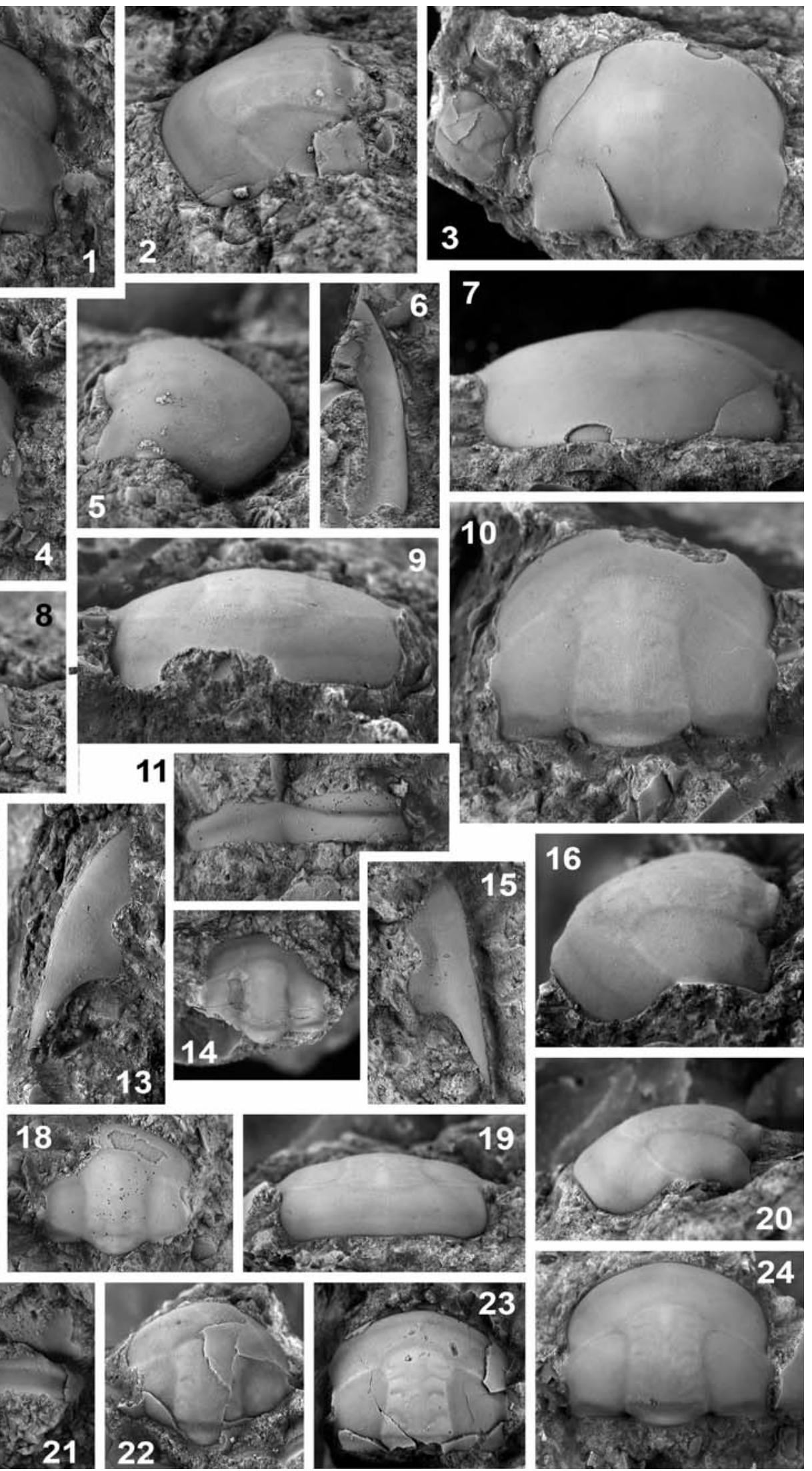
DESCRIPTION OF ADULT MORPHOLOGY: Cranidium with width/length ratio of about 0.85 . Anterior margin gently and evenly curved. Palpebral lobes extending slightly beyond tips of the anterior sections of the facial suture, anterior end of palpebral lobes opposite or slightly posterior to S3. Cranidium of fairly even convexity, similar to a spherical segment, with only glabella slightly elevated, palpebral lobes somewhat upturned, occipital lobe developed as low transverse ridge, and fixigenae less clearly convex.

Glabella 81 to $84 \%$ cranidial length and a maximum width across L1 of 42 to $45 \%$ cranidial width across centre of the palpebral lobes; lateral sides clearly concave in dorsal view, with maximum constriction at or slightly anterior to S2; expansion at or slightly posterior to frontal lobe attains almost the width across L1, expansion results from a fusion with projections of the eye ridges. Front with low to moderate curvature in dorsal view. Three to four pairs of lateral glabellar furrows, all of them faintly impressed to obsolescent on the exterior of the test, all of them quite short and clearly separated at midline; S1 and S2 moderately directed rearward; S3 slightly longer and slightly more oblique rearwards. Occipital furrow very shallow, forming a shallow and sagittally relatively broad depression medially, lateral sections short and obsolescent, swinging backwards, terminate distant from axial furrows. Occipital ring sagittally of about $10 \%$ cephalic length, forming a transversely subelliptical to sublenticular low ridge with a moderately curved posterior margin.

Axial furrows obsolescent, only developed as minor changes in convexity on the shell exterior. Fixigenae low, forming weakly convex subsemicircular areas; extend across centre of palpebral lobes to slightly more than half maximum width of glabella; exsagittally of slightly more than $45 \%$ cephalic length next to axial furrows.

Palpebral lobes small, with fairly low curvature at ocular suture, with moderate transverse convexity, but distal portions more raised and thus slightly upturned in respect to the overall convexity of the cephalon; breadth only about 6 to $8 \%$ of maximum glabellar width, exsagittal length in large individuals about 22 to $24 \%$ cranidial length; situated at a fairly posterior position: anterior ends opposite S3 or slightly posterior to its level, posterior tips opposite S1. Palpebral furrows a very shallow, weakly defined, almost straight and somewhat obliquely directed depression. Eye ridges very low, obsolescent ridges, only recognizable as minor changes in convexity on the shell exterior, projecting from near anterior ends of palpebral lobes obliquely forward to merge with the anterolateral corners of the glabella.

Anterior branches of the facial suture weakly diverging from anterior ends of visual surface, faintly curved. Posterior branches moderately long, weakly diverging from posterior ends of palpebral lobes, almost straight in dorsal view for most of the distance, with only minute curvature shortly anterior to posterior margin, posterolateral tips extending to about the level of the palpebral lobes' maximum distance from midline.

Preglabellar field sagittally c. 11 to $14 \%$ cephalic length, follows more-or-less the sagittal curvature of the glabella, in some species obsolescent median plectrum faintly indicated. Preocular fields likewise slightly concave, sloping ventrally.

Anterior border sagittally of c. $10 \%$ cephalic length, poorly defined by obsolescent border furrows. Posterior border consists of an exsagittally narrow, more-or-less straight, barely elevated adaxial section, and somewhat nodular, elevated fulcral extension from which the abaxial section is developed as a simple deflected flap defined by a slightly forward curvature of the cephalic margin. Posterior border furrow obsolescent.

Librigena with relatively narrow ocular platform and wide lateral border separated by change in convexity only. Lateral border extends into a moderately long and broad genal spine of roughly two-thirds the length of the rest of the librigena. Lateral margin with very low curvature for most of the distance so that the genal spines are directed obliquely rearward. Straight posterior margin swings back into the genal spine in a gentle curvature so that the base of the genal spine is conspicuously broad. Doublure wide (Text-fig. 12.6).

Thorax known only from disarticulated thoracic segments. Axial rings wide, moderately convex in transverse section and with low convexity in sagittal section; anterior margin defined by slightly rearward swinging, well impressed axial furrow in normal segments, but obviously with distinct rearward bend in segments 1 and 2 (Text-fig. 12.11). Posterior margin moreor-less straight. Articulating half-ring moderately wide (sag.) and distinctly convex, acutely tapering laterally, not reaching to the axial furrows. Axial furrows developed as distinct changes in convexity only, curved in dorsal view.

Pleurae short, transverse width slightly greater that half width of axial ring, in anterior tergites with anterior margin straight and normal to axis up to a weakly developed fulcral process about half way between dorsal furrows and pleural tips, curves rearward abaxial to the fulcral process. Anterolateral portion developed as a strongly deflected facet abaxial to fulcral socket. Posterior margin of pleurae with straight adaxial section normal to axis up to a slight elevation about half distance between dorsal furrows and pleural tips that forms an indistinct socket corresponding to the fulcral process of the adjacent tergite; posterior margin of pleura faintly back- 
ward directed abaxially of the socket. Pleural tip developed as triangular truncated ends, without spines. Pleural ribs low to moderately convex, divided by oblique pleural furrow developed as a wide and poorly defined groove, which commences somewhat distant from axial furrows and fades distant from pleural tips; anterior rib extends into the pleural tip to create slightly elevated part; posterior rib somewhat triangular, does not reach pleural tip.

Surface of cephalon smooth except for few low terrace ridges close to the anterior and lateral margin and the genal spine. Thoracic segments smooth except for a few small, wrinkled terrace ridges close to the pleural tips.

\section{ONTOGENETIC VARIABILITY AND PHYLOGE-}

NETIC IMPLICATIONS: Juvenile specimens of Kingaspis campbelli differ in several respects from adult specimens. Most of these differences focus on the convexity and the proportions of the cephalon. Particularly noteworthy is that the individual parts of the cranidium show their own convexity in juvenile specimens so that the glabella is elevated above moderately convex fixigenae and separated from the preglabellar front. The palpebral lobes are wider and more clearly upturned, and the eye ridges form recognizable low ridges. The posterior border furrow is moderately well developed as a groove increasing in exsagittal width toward the facial suture; the posterior border is somewhat upturned. No distinct differences in the morphological expression compared to adult individuals are evident for the glabellar furrows, the occipital ring, and the anterior border. However, the glabellar furrows, particularly S1 and S2, are visible for a longer distance and thus more strongly recurved, and the preglabellar field carries weakly developed caeca on internal moulds.

The differences in the proportions have an effect on the glabella, which is relatively longer (up to nearly 85 $\%$ cephalic length in juvenile specimens) and has its widest portion across the anterolateral corners. The glabellar front is more strongly curved, and the occipital ring is sagittally broader and reaches $17 \%$ cephalic width in the material and shows a tendency to a subterminal node (Text-fig. 12.14, 12.18). The palpebral lobes are slightly longer (exsag. up to $30 \%$ cephalic length) and clearly wider as well as more elevated and more strongly curved at the rim of the visual surface.

These differences between adult and juvenile morphology of Kingaspis campbelli reflect in total a progressive smoothing of the surface with the tendency to attain the morphology of a spherical segment. The effacement recapitulates the supposed phylogenetic development within the clade, particularly the develop- ment from Kingaspidoides to Kingaspis which represents one evolutionary pathway among the Ellipsocephalinae. Apart from minor characters, juvenile cranidia of Kingaspis resemble those of adult Kingaspidoides Geyer, 1990b so that the distinct modifications during later stages determine the generic identity. This development is a paradigm for Ernst Haeckel's basic concept of his "law of recapitulation" and certainly one of the few examples of this rule known from early and middle Cambrian trilobites. It provides the direction of the phylogenetic changes and thus indicates indeed that Kingaspis is derived from Kingaspidoides and thus phylogentically younger. In terms of heterochrony, however, the more or less equal size of Kingaspidoides and Kingaspis combined with an increasing development of shape places its development under the category acceleration, despite the fact that the newly acquired reduced relief would have been regarded as an indication for neoteny without knowing the direction of the evolutionary development. In addition, this development is a stratigraphic argument that provides a further prove for the age assignment of the Wadi Zerqa Ma'in faunule.

DISCUSSION: As mentioned earlier (Geyer and Landing 2004), specimens identified from Spain as Kingaspis campbelli by Liñán et al. (2003) are considerably distorted and usually do not show the precise morphology of the external surface. As detailed by Geyer (1990b), kingaspidoid genera such as Kingaspis Kobayashi, 1935; Kingaspidoides Hupé, 1953a; and Ornamentaspis Geyer, 1990b, can be identified with certainty and used in precise correlations only if the detailed morphology of the external and internal surfaces is known. For this reason, the Spanish material is not precisely determinable. However, the internal moulds of the specimens identified as Kingaspis (K.) campbelli from the Iberian Chains represent a species different from K. campbelli. This species has pronounced triangular projections of the anterolateral corners of the glabella created by the protruding eye ridges. As noted by Geyer and Landing (2004), one principal character in adult specimens of $K$. campbelli is that the anterior facial suture meets the margin posterior to the anterolateral corners of the glabella - a character that is distinctly different in the Spanish material. Gozalo et al. (2007) noted that this character appears to be variable in the specimens figured by Rushton and Powell (1998, figs 21-26). However, these specimens are not all oriented with the palpebral lobes in a horizontal line. In addition, the specimens from the Iberian Chains have a more elevated glabella and show palpebral lobes in a more anterior position. 
Uhaymiria gen. nov.

TYPE SPECIES: Uhaymiria glabra gen. nov., sp. nov., by monotypy.

ETYMOOGY: Named after the Wadi Uhaymir, Jordan, in which the type material was collected.

DIAGNOSIS: Genus of the Subfamily Ellipsocephalinae with glabella c. $85 \%$ cephalic length, slightly tapering forward, frontal lobe moderately wide, subtruncate; three pairs of weakly impressed, roughly parallel glabellar furrows; occipital ring broad (sag.), more than one-fourth glabellar length, with subterminal thorn; fixigenae weakly convex, simple; palpebral lobes reaching posterior border furrow, separated from eye ridges by weak depression only; eye ridges oblique, meet dorsal furrows at level of S3 and tend to bifurcate to produce obliquely forward-directed low ridges which separate the preglabellar field and preocular areas; preglabellar field and preocular areas low, flat to faintly concave; anterior border wide, slightly convex, poorly delimited from preglabellar field.

DISCUSSION: Uhaymiria gen. nov. is a genus typical of the Ellipsocephalinae with fairly effaced morphology. The basic pattern of three pairs of lateral glabellar furrows on the slightly tapering glabella is difficult to recognize. The long palpebral furrows which are slightly arched against the eye ridges, and fixigenae without particular characters also belong to this basic bauplan resulting in the usual mosaic pattern of ellipsocephaloid characters. However, Uhaymiria does not belong to the notoriously "smooth" ellipsocephaloid group with Kingaspis Kobayashi, 1935, Ellipsocephalus Zenker, 1833 or Ornamentaspis Geyer, 1990. This is unequivocally displayed by its subtruncate glabellar front and the broad (sag.) occipital ring. Other diagnostic diagnostic characters include the strange bifurcation of the eye ridges with obliquely forward-directed anterior branches which extend to the anterior border as faint lines and separate the preglabellar field from the preocular areas.

Uhaymiria glabra gen. nov., sp. nov. (Text-fig. 13)

ETYMOLOGY: From the Latin glabrum, smooth; a reference to the effaced morphology and the low overall convexity of the cranidium.

HOLOTYPE: Incomplete cranidium, FG-602-067c.

PARATYPE: Incomplete cranidium, FG-602-008a. Both from the Wadi Uhaymir section, Jordan.

DIAGNOSIS: Diagnosis of genus (because of monotypy).
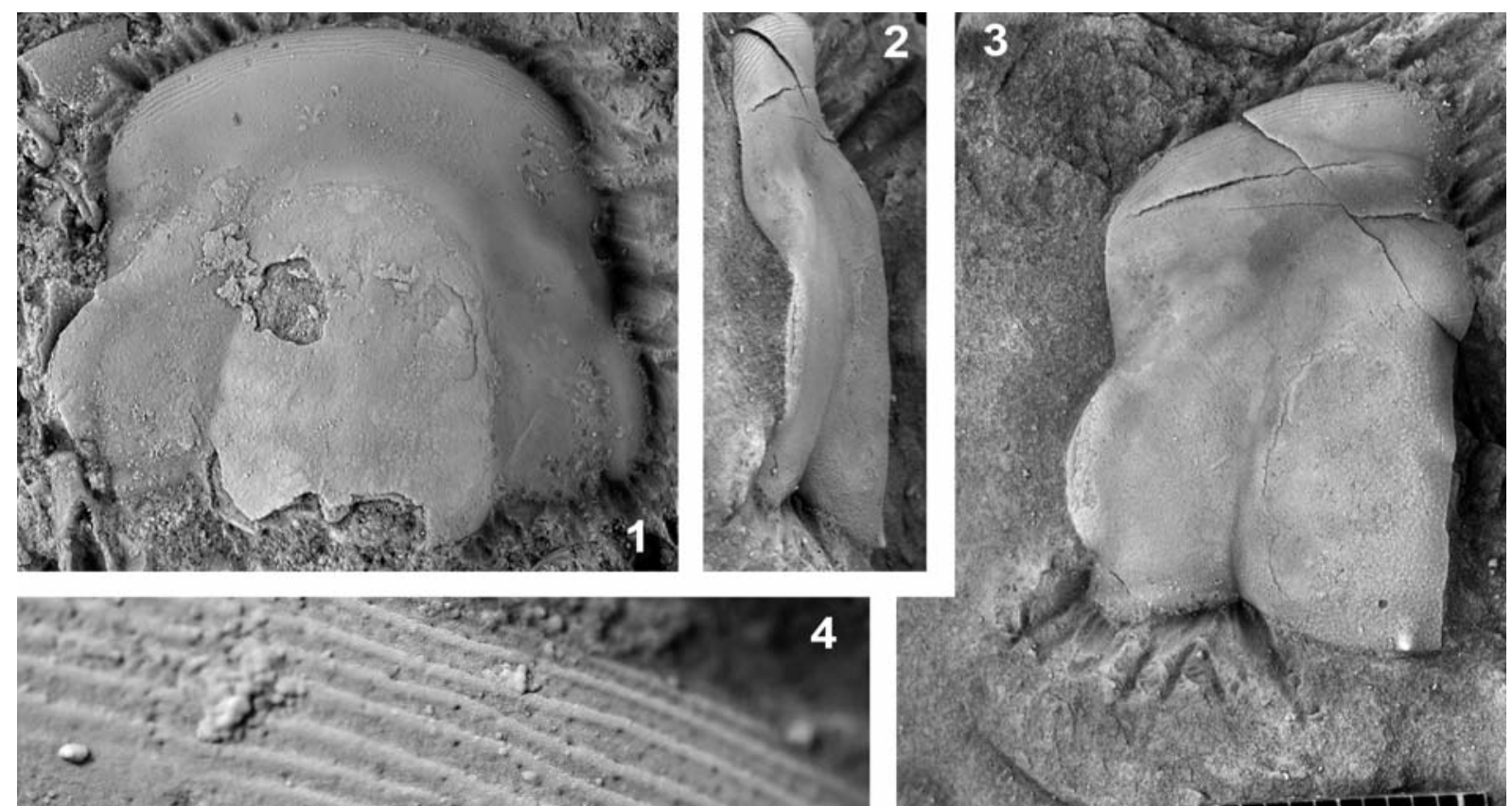

Text-fig. 13. 1-4 - Uhaymiria glabra gen. nov., sp. nov. 1; specimens from the Wadi Uhaymir section. 1, 4- FG-602-067c, partial cranidium, dorsal view, $\times 3$; 2 - detail of anterior border showing terrace ridges and pits, $\times 12 ; 2,3-$ FG-602-008a, partial cranidium, left lateral and dorsal views, $\times 1.5$ 
DESCRIPTION: Cranidia 21.0 and $19.9 \mathrm{~mm}$ long, with width/length ratio of about 0.85 . Anterior margin gently curved. Palpebral lobes extend laterally beyond anterior sections of the facial suture. Glabella moderately convex, slightly less than $80 \%$ cranidial length and approximately half cranidial width across occipital ring; slightly tapering forward, with more-or-less straight sides; frontal lobe wide, slightly more than $40 \%$ cranidial width, with very gently curved anterior margin. Three pairs of obsolescent lateral glabellar furrows, indicated only as faint semi-lateral depressions. Occipital furrow an indistinct to obsolescent transverse groove. Occipital ring sag. broad, up to $20 \%$ cephalic length and more than quarter glabellar length, with a moderately curved posterior margin and a short subterminal thorn.

Axial furrows shallow next to proximal areas of fixigenae, poorly defined between eye ridges and glabella. Fixigenae with low convexity, their width across centre of palpebral lobes equals c. $45 \%$ width of occipital ring; exsag. length next to axial furrows about $45 \%$ cephalic length.

Palpebral lobes moderately long (roughly one-third cephalic length), gently curved at ocular suture, transverse width about equal throughout or with slightly narrower (tr.) anterior portion and with moderate transverse convexity; anterior ends at supposed level of L3, posterior tips at about level of anteriormost part of occipital ring, at short distance from posterior border. Palpebral furrows shallow and narrow, weakly defined. Eye ridges project from palpebral lobes, delimited from palpebral lobes by a narrower and less elevated portion, weakly defined, form long elliptical swellings oblique to axis; anterior ends of eye ridges well separated from glabella but with faint trifurcation into threads prograding towards the posterior part of the frontal lobe, towards the anterior part of the frontal lobe, and obliquely forward in the direction of the anterior border (Text-fig. 13.1). This low anterior branch separates the preglabellar field from the preocular areas.

Anterior branches of the cephalic facial suture subparallel from anterior ends of the visual surface, gently curved adaxially when reaching anterior border. Posterior branches not well preserved, moderately long, probably clearly diverging in dorsal view.

Preglabellar field a sagittally broad, faint depression grading into the anterior border. Preocular fields exsag. fairly broad, ventrally sloping areas.

Anterior border low, barely convex, poorly defined, characterized mainly by the presence of terrace ridges, sagittal length c. 5-7 \% cephalic length. Anterior border furrow obsolescent. Posterior border convex, slightly backwardly directed and wider abaxially. Posterior border furrow a shallow, poorly defined and fairly narrow groove.

Librigena, thorax, and pygidium unknown.

Surface of cranidium smooth. Anterior border with distinct terrace ridges. Between the terrace ridges are fine punctae (Text-fig. 13.3) which are interpreted to represent the positions of sensory organs.

DISCUSSION: See discussion under genus.

Subfamily Protoleninae Richter and Richter, 1948

Cambrunicornia Geyer, 1990b

TYPE SPECIES: Cambrunicornia vanlooyi Geyer, 1990; by original designation.

Cambrunicornia? jafnaensis sp. nov. (Text-fig. 14)
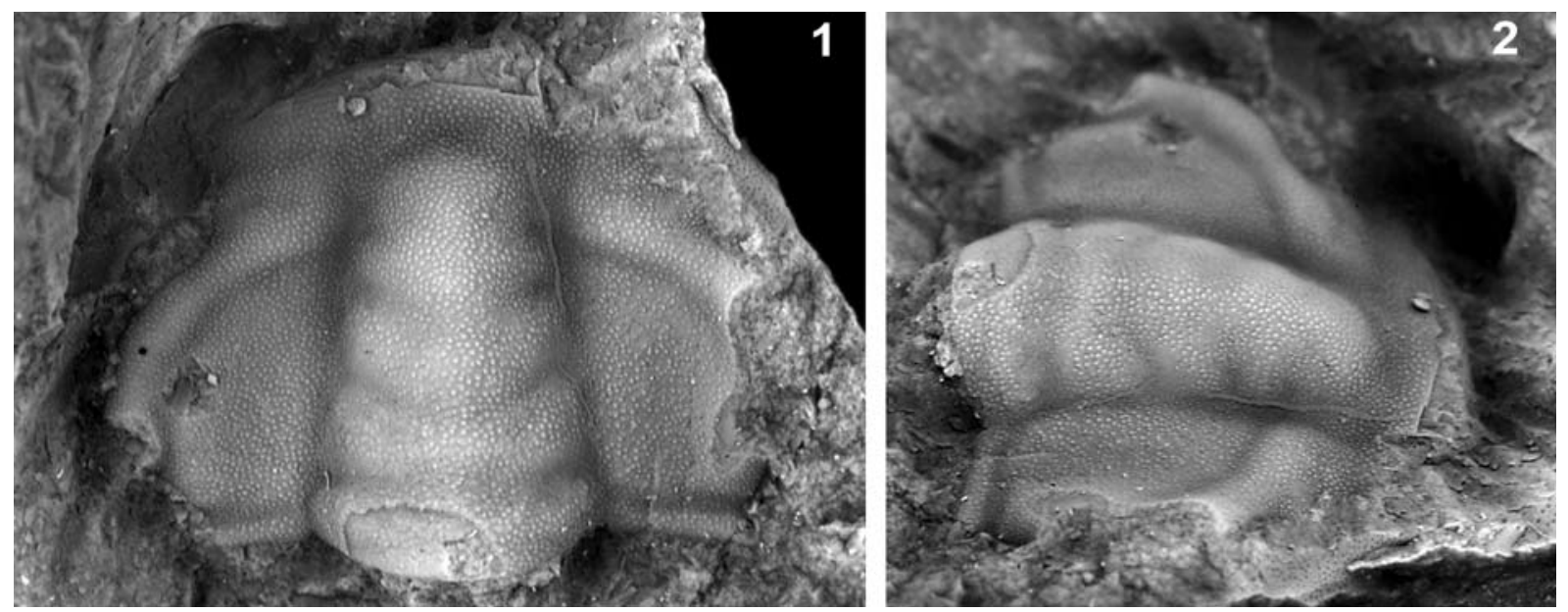

Text-fig. 14. 1-2 -Cambrunicornia? jafnaensis sp. nov.; FG-602-078, incomplete cranidium, from the Wadi Umm Jafna section; dorsal view and oblique right lateral views, $\times 8$ 
DERIVATION NOMINIS: Named after the type locality at Wadi Umm Jafna.

HOLOTYPE: Incomplete cranidium, FG-602-078, from Wadi Umm Jafna section, Jordan.

DIAGNOSIS: Species tentatively assigned to Cambrunicornia with a more-or-less evenly tapering glabella of c. $80 \%$ cephalic length, with three pairs of protolenid-type glabellar furrows; frontal lobe narrow, c. quarter maximum cranidial width, subtriangular, without swelling or spine; fixigenae with small bacculae on posteroproximal portions and weakly raised distal portions separated by shallow longitudinal depression.

DESCRIPTION: Cranidium with width/length ratio of about 0.8 . Anterior margin apparently gently curved. Palpebral lobes clearly extending laterally beyond tips of the anterior sections of the facial suture. Glabella slightly more than $80 \%$ cranidial length and $43 \%$ cranidial width across occipital ring; distinctly tapering forward, with approximately straight sides; frontal lobe narrow, almost precisely quarter maximum cranidial width, with subarcuate anterior margin; glabella highly convex. Three pairs of lateral glabellar furrows present, all of them distinctly impressed; S1 and S2 directed moderately rearward and fairly long, indistinctly separated across midline; S3 a short depression close to the axial furrows. Occipital furrow a distinctly impressed, wide and indistinctly delimited furrow with shallow median section. Occipital ring sagittally of c. $13 \%$ cephalic length, with a moderately curved posterior margin and a probably short subterminal spine (only imperfectly preserved on internal mould).

Axial furrows varying from shallow next to proximal areas of fixigenae to moderately deep between eye ridges and glabella. Fixigenae with small bacculae on posteroproximal portions and weakly raised distal portions paralleling palpebral lobes, separated by shallow and weakly defined longitudinal depression; width across centre of palpebral lobes half maximum width of occipital ring; exsag. length next to axial furrows slightly less than half cephalic length.

Palpebral lobes moderately long (c. $40 \%$ cephalic length), gently curved at ocular suture, transverse width about equal throughout, with distinct transverse convexity; anterior ends at level of S3, posterior tips at about level of anterior limits of occipital furrow, distinctly distant from posterior border. Palpebral furrows shallow and narrow, weakly defined. Eye ridges project from palpebral lobes, delimited from palpebral lobes by a narrower and less elevated portion, fade towards axial furrows; anterior section of eye ridges appears to swing for- ward next to glabella, but progression not clearly recognizable.

Anterior branches of facial suture not well preserved, probably subparallel. Posterior branches not preserved, moderately long, probably clearly diverging in dorsal view.

Preglabellar field a sagittally narrow area, developed as a low medial groove grading into the anterior border. Preocular fields narrow and slightly convex, ventrally sloping areas.

Anterior border poorly preserved, only defined by the presence of relatively coarse terrace ridges, sagittally of c. $5 \%$ cephalic length. Anterior border furrow obsolescent. Posterior border convex, more-or-less straight and with little variation in breadth over the preserved section, sloping ventrally. Posterior border furrow a moderately deep groove.

Librigena, thorax, and pygidium unknown.

Surface of the cranidium densely covered with moderately coarse granules except for the smooth lateral portions of the glabellar furrows. The size of the granules varies slightly, being coarsest on the elevated parts of the glabella and slightly more than half this size on the palpebral lobes and the adjacent palpebral furrows and distal parts of the fixigenae. Anterior border with terrace ridges.

DISCUSSION: Species similar to Cambrunicornia? jafnaensis sp. nov. are placed under Cambrunicornia Geyer, 1990, a genus which appears to include species with a fairly wide morphologic range. Geyer (1990b) introduced the genus for two species with a node or small spine on the frontal lobe in adult specimens, which creates the reference for the name ("Cambrian unicorn"). These species share the more-or-less evenly tapering glabella with protolenid-type glabellar furrows, a sagittally narrow, sunken preglabellar field prograding into a low and fairly indistinct anterior border. In addition to the two formally introduced species of Cambrunicornia from Morocco, C. agdziensis Geyer, 1990 and the type species C. vanlooyi Geyer, 1990, the genus is known from incomplete sclerites of a new species from a fauna of earliest middle Cambrian age of the Tröbitz Formation of Germany (Elicki and Geyer 2010). The new species from Jordan agrees in morphology with these species, but lack the node or spine on the glabellar frontal lobe and has a Protolenus-type of fixigenae which differs from the Ornamentaspis-type known from the Moroccan species of Cambrunicornia.

Family Bathynotidae Hupé, 1953b

DISCUSSION: Onaraspis and the Onaraspis clade 
pose a serious problem in its taxonomic placement as exemplified by its earlier treatment. A quite recent assignment of Onaraspis was ventured by Jell and Adrain (2003), who placed the genus in the Metadoxididae. By contrast, Sepkoski (2002) placed it, in a generalized manner, in the Redlichiida, and Yuan et al. (2002) tentatively in the Redlichioidea.

The key for a correct understanding, however, may be the morphologically unique genus Bathynotus Hall, 1860. Bathynotus is a trilobite genus known from Laurentia, South China, Australia and Siberia, and therefore suitable to enhance the resolution of intercontinental correlation in the traditional Lower-Middle Cambrian boundary interval. Such stratigraphical considerations have been described in detail by Geyer and Peel (2011).

Webster (2009) presented comprehensive morphometric data from representatives of all nine previously described species and, based on multivariate and bivariate analyses, recognised a total of only four species, B. holopygus (Hall, 1859) (from eastern Laurentia and South China), B. granulatus Lermontova, 1940 (including its junior synonym B. elongatus Zhao et al., 1987; known from the Siberian Altay-Sayan foldbelt, South China, and western Laurentia), B. kueichouensis Lu in Wang, 1964 (from South China and Australia) and B. namanensis Lermontova, 1940 (from the Siberian Platform).

The family Bathynotidae was treated earlier as a distinct suborder, Bathynotina Lochman-Balk, 1959, of the Redlichiida (Lochman-Balk 1959), whereas during the last two decades the family was usually treated as of uncertain higher systematic position. Bathynotus and thus the Bathynotidae share many characters with taxa of the Redlichiina, namely a tapering glabella with a comparatively simple set of lateral glabellar furrows; long and crescentic palpebral lobes, an opisthoparian facial suture; librigenae with long genal spines; and a fairly wide thoracic axis with axial nodes. However, most of these characters are plesiomorphic and simply portray a "primitive" character set.

A particular character of the dorsal carapace shared with few Redlichiine trilobite taxa, however, is the thorax consisting of 13 thoracic segments with the 11th segment being macrospinose. A comparable thoracic morphology is only known in the Metadoxididae and the Saukiandidae. The ventral morphology of the Bathynotidae, as shown by Bathynotus holopygus, is also characteristic. The hypostome of this species is conterminant and without a recognizable rostral plate so that oblique anterior sutures separate the hypostome from the anterior doublure, giving the hypostome a roughly pentagonal shape. Whittington (1988) suggested that the triangular area in front of the median body in the hypos- tome of Bathynotus may represent a remnant of the rostral plate, fused with the hypostome. If this interpretation is correct, the sutures with the anterior doublure would be connective sutures separating the doublure from the unrecognizable rostral plate. In nearly all other trilobites with small rostral remnants, the typical pattern for such sutures is a divergence towards the anterior rather than a convergence toward an apex, so this feature clearly distinguishes Bathynotus from all well known Redlichiida. This considered, Whittington (1997) emphasized the unique character of this sutural contact. It should be noted that a similar discussion with some additional comparisons is placed on Sam Gon's trilobite website under $<$ http://www.trilobites.info/bathynotidae.htm>.

Although the hypostomal attachment is unique among the trilobites, the newly discovered material of Myopsolenites palmeri (described below; Text-fig. 14.810) exhibits a conterminant hypostome with a completely fused rostral plate. The connective sutures with the ventral doublure are generally straight in exsagittal direction, but have a slight median convergence.

The pygidial morphology is exemplified by such material as of Bathynotus sp. indet. from the Pioche Formation of Lincoln County, Nevada, USA (Webster 2009, fig. 4), which shows a remarkable conformance with pygidia of Myopsolenites from Jordan. In addition, specimens of immature individuals from the Wadi Uhaymir section described below under Myopsolenites hyperion sp. nov. exhibit a morphology which very much resembles that of imperfectly preserved immature specimens of Bathynotus spp. from South China, again indicating a close phylogenetic relationship of Myopsolenites and Bathynotus.

Considering Whittington's (1988) arguments, and the strikingly similar dorsal morphology, Myopsolenites and the Onaraspis-clade in general is best placed in the Family Bathynotidae. As pointed out by Żylińska and Masiak (2007), other possible relatives which are as yet unsufficiently known include Conomicmacca plana (Matthew, 1895) from the Protolenus elegans Zone of southern New Brunswick, Canada (Westrop and Landing 2000), Bathynotellus yermolaevi Lermontova, 1940 from Novaya Zemlya, Russia (Lermontova 1940), and Rectifrontinella olhae Konstantinenko, 2001 from the Carpathian Foredeep in the Ukraine (Drygant and Konstantinenko 2001).

It should also be noted that Bathynotus has been placed under the Chengkouaspidae by Jell and Adrain (2003), which was regarded by these authors as a redlichioid family. Nevertheless, most East Asian taxa exhibit characters which appear to mark them as a primordial lineage of corynexochoid trilobites (which would include the Acanthomicmacca clade). 
Despite the extremely limited knowledge on the ventral morphology of most Redlichiida, a few older species with a similar conterminant hypostomal pattern, such as in the emuellid Balcoracania Pocock, 1970 and particularly in Saukianda (as shown by material from the Issafen Syncline, Moroccan Anti-Atlas), make it the most parsimonious solution to place the $\mathrm{Ba}$ thynotidae as a higher taxon under the Redlichiida.

\section{Genus Myopsolenites Öpik, 1975}

TYPE SPECIES: Myopsolenus palmeri Parnes, 1971; Timna Formation, Timna area, southern Israel.

EMENDED DIAGNOSIS: Bathynotid genus characterized by a cephalon with low overall convexity; glabella tapering forward, front subtruncate, reaching anterior border; three pairs of lateral glabellar furrows, S1 longer than S2 and S3, and with a tendency to be connected medially; anterior border with low convexity, slightly sloping rearward from anterior rim, anterior border furrow weakly impressed. Thorax in adult individuals with twelve to fourteen segments, with tenth, eleventh or twelfth segment conspicuously macropleural and thoracic tergites posterior to the macropleural segment reduced in size. Pygidium shield-like, with long, multisegmented axis; pleural fields with shallow to modestly developed furrows; lateral and posterior border obsolete, lateral and posterior margins smooth, usually gently curved. Rostrohypostomal plate with broadly connected rostral and hypostomal units; lateral sutures parallel or slightly diverging forward.

DISCUSSION: As detailed by Geyer and Landing (2004), the genus Myopsolenites Öpik, 1975, was based on a species described by Parnes (1971) as Myopsolenus palmeri from the Timna Formation of southern Israel. Myopsolenus is now regarded as a subgenus of the protolenoid genus Hamatolenus Hupé, 1953a (see Geyer 1990b and Geyer and Landing 2004). Öpik (1975) recognized significant generic (and supra-generic) differences, and proposed the new genus Myopsolenites for the Israeli species. Unfortunately, he named the new genus without a thorough discussion and only in a caption of a table (Öpik 1975, p. 8, table caption) so that this naming has been misinterpreted as a type error for the (morphologically significantly different) Genus Myopsolenus Hupé, 1953 (see Geyer 1990b, p. 175, and Żylińska and Masiak 2007 for further discussion).

The type material of Myopsolenites palmeri (Parnes, 1971) from the Hakhlil Member of the Timna Formation was based on incomplete and poorly preserved speci- mens, which were restudied by one of the authors (GG). The material is now housed in the Geological Survey of Israel, Jerusalem. This species shows the same general type of thorax and pygidium as the Australian Onaraspis somniurna Öpik, 1968, but differs in the cephalic morphology and the overall size (see below for further discussion). Although a precise correlation of the strata with $M$. palmeri was unknown, the presence of the genus in northwestern Gondwana significantly expanded the geographic distribution of Onaraspis-clade trilobites.

Over the last decades the known geographic range became even larger. Together with recent finds in Morocco (Geyer and Landing 2004), the clade now appears to have had its maximum diversity in West Gondwana. The previously known specimens of Myopsolenites palmeri from the southern Negev are relatively poorly preserved and do not unequivocally preserve the morphology of the species. What can be seen is that the glabella progressively tapers forward to a subtruncate front. The eye ridges commence at S3 and run more-or-less straight posteriorly and abaxially. The well-elevated palpebral lobes are oblique to the axis and moderately long. The occipital ring carries a stout terminal node. The anterior border is slightly elevated anteriorly, but weakly defined towards the preglabellar field. The holotype (Parnes 1971, pl. 3) is a fairly complete but slightly disarticulated specimen (due to the moulting process) that is more than 120 $\mathrm{mm}$ in length. Due to the cranidium being dislocated from the thorax, the exact number of thoracic segments cannot be counted with certainty. However, the specimen's taphonomically modified condition suggests that the thoracic segments are all preserved, with only the anteriormost tergite disconnected from the rest of the thorax. Therefore, the thorax seems to have twelve segments, with a macropleural tenth followed by two tergites of reduced size between it and the pygidium. The pygidium is quite well known from additional material. It has relatively gently curved lateral margins, shallow interpleural furrows only on the anterior parts of the pleural fields, and successively shallower furrows across the axis. An additional small specimen from the same locality at Har 'Amram (Parnes 1971, pl. 4, figs 35-36) also has twelve thoracic segments. The best preserved type specimens were collected at Har 'Amram and have been considered to come from the Mikhrot Member of the Timna Formation. Additional material of the type lot from the overlying Hakhlil Member of the Timna Formation in Timna National Park suggests that the stratigraphy at Har 'Amram has been incorrectly interpreted, and that the specimens may indeed come from the Hakhlil Member. Additional material collected by G. Geyer and E. Landing at Timna clearly shows the cranidial features, such as a stout terminal occipital node; a relatively straight, well impressed 
occipital furrow with a shallower part medially; posterior lateral glabellar furrows (S1) that are not clearly deeper than S2 or S3; low, almost straight eye ridges that are connected with and progressing into a parafrontal band; and moderately curved, medium-sized palpebral lobes, the posterior ends of which are clearly distant from the posterior border furrow. In summary, the small number of thoracic segments, the comparatively short (exsag.) palpebral lobes, and the shallow lateral glabellar furrows S1 serve to distinguish Myopsolenites palmeri from the three other species assigned to this genus (Table 1).

A species first described as Perrector? altus Liñán and Gozalo, 1986 from the "Bilbilian Stage" (abandoned designation; now upper Banian through lower Agdzian; see Geyer and Landing 2004) of the Iberian Chains, northern Spain, has been reassigned to Myopsolenites altus by Geyer and Landing (2004) and to Onaraspis altus by Dies (2004). Geyer and Landing (2004, p. 200; 2007, p. 22) argued that the species was difficult to characterize on the basis of the type material from the Valdemiedes Formation at the Rambla de Valdemiedes due to strong distortion, but emphasized the great similarity with the Moroccan species Myopsolenites boutiouiti Geyer and Landing, 2004. Minor differences were seen in the more robust genal spines and the somewhat less curved palpebral lobes of the Anti-Atlas specimens, but the distinguishing characters were accepted from the original description by Liñán and Gozalo (1986, p. 44), who had described M. altus as having a thorax consistently with fourteen segments, and with three segments posterior to the macropleural eleventh segment. In contrast, exoskeletons of adult individuals of $M$. boutiouti have no more than thirteen thoracic segments, and with only two posterior to the macropleural eleventh segment. Geyer and Landing (2004, p. 200) emphasized that "additional, better preserved material of $M$. altus will probably reveal additional characters that distinguish the species". Myopsolenites altus was redescribed by Dies Álvarez et al. (2007), who noted a "thorax composed of thirteen segments" (p. 424) and the tenth thoracic segment as be- ing "macropleural with a thin, long spine extending to the pygidium" [sic!]. Indeed, some of the figured specimens indicate substantial differences against the original descriptions by Liñán and Gozalo (1986) and that of Dies Álvarez et al. (2007) as pointed out by A. Vincent (written comm. to GG, 2009). Figure 2 in Dies Álvarez et al. (2007) shows several fairly complete exoskeletons, of which the left specimen in text-fig. $2 \mathrm{C}$ has a macropleural eleventh segment followed by two segments with small pleurae. The specimens in text-figs 2D, 2G, and fig. 3A in Dies Álvarez et al. (2007) show the same configuration whereas the specimen in textfig. $2 \mathrm{E}$ shows that the macropleural segment is the eleventh. The situation of the right specimen in text-fig. $2 \mathrm{C}$ is not unequivocally determinable from the published photograph. The pleural spines of the macropleural segments are apparently somewhat more slender than those seen in the slightly larger specimens described as M. boutiouiti from the Anti-Atlas. However, these differences may be attributed to intraspecific variability, ontogenetic differences, and/or the different degree of deformation. Consequently, we regard $M$. boutiouiti Geyer and Landing, 2004 as a junior synonym of M. altus (Liñán and Gozalo, 1986). The biostratigraphic implications for correlation between Iberia and the Moroccan Atlas regions are discussed above under Correlation.

Another species of Myopsolenites was described as "?Jakutus kielcensis" by Bednarczyk (1970) from the Brzechów area in the Świętokrzyskie (Holy Cross) Mountains of southern Poland (Geyer and Landing 2004; Żylińska and Masiak 2007). This species differs from M. altus in having distinctly shorter eye ridges and, as a result, narrower fixigenae and palpebral lobes that are somewhat more oblique to the axis. The pygidium of M. kielcensis is narrower, with distinctly less curved lateral margins so that the outline is more-or-less "heartshaped", in contrast to the subrounded to subparabolic pygidium of $M$. altus. In addition, the almost smooth lateral border is much narrower (tr.) in the pygidium of $M$. kielcensis than that in M. altus.

\begin{tabular}{|l|l|l|l|l|}
\hline Species & S1 & palpebral lobes & thoracic segments & pygidial outline \\
\hline M. palmeri & shallow, disconnected & moderately long & $12-13$ & subtriangular \\
\hline M. hyperion & shallow, disconnected & relatively short & $(12-) 13$ & subparabolic \\
\hline M. altus & $\begin{array}{l}\text { well impressed, } \\
\text { transglabellar }\end{array}$ & moderately long & 13 & subparabolic \\
\hline M. kielcensis & $\begin{array}{l}\text { well impressed, } \\
\text { transglabellar }\end{array}$ & relatively short & unknown & subtriangular \\
\hline
\end{tabular}

Table 1. Comparative morphologies of four Myopsolenites species 
MODE OF LIFE: The characters of the dorsal carapace (particularly those of the thoracic segments) suggest that the species of Myopsolenites from Jordan described below, were able to considerably incline the body and to curve the thorax concavely in longitudinal section. This leads to the assumption that the ventral appendages were able to dig in the substrate and possibly created Rusophycus-type resting trails. Prerequisites of such a mode of life are strongly developed ventral appendages, the suggested presence of which is in perfect accordance with paired bulbous structures on the axial rings close to the axial furrows, which obviously depict the attachment sites of strong dorsoventral muscles to the ventral/internal surface of the shell. Rusophycus- and Cruziana-type traces were found in the predominantly siliciclastic rocks coeval with the Myopsolenites palmeri-bearing beds in the Timna area, southern Israel (Geyer and Landing, unpubl. results). Those Cruziana traces with multiple distinct scratch marks of sharp claws can be identified as Cruziana salomonis Seilacher, 1990. Its size and occasional imprints of pygidial margins fit perfectly with the characters seen in Myopsolenites.

\section{Myopsolenites hyperion sp. nov.}

(Text-figs 9.6?, 9.7?, 15)

ETYMOLOGY: Named after Hyperion, a member of the Greek divine gender of the Titans.

HOLOTYPE: Incomplete dorsal carapace, FG-602-065. PARATYPES: Four incomplete cranidia, FG-602058b, FG-602-058c, FG-602-058d; thorax with attached pygidium, FG-602-056a; incomplete pygidium, FG-602-058c. Material tentatively assigned to $M$. $h y$ perion: incomplete cranidium and partial thorax of immature individual, FG-602-049a; dorsal carapace of late meraspid individual, FG-602-014a. All specimens from the Wadi Uhaymir section, Jordan.

DIAGNOSIS: Species of Myopsolenites with moderately tapering glabella with shallow, medially disconnected S1 and weakly curved front; palpebral lobes moderately long in adults; adult thorax with twelve to thirteen segments; occipital and thoracic rings with subterminal nodes; pygidium with gently curved lateral and posterior margins, either subparabolic to heart- shaped in outline or subelliptical with median indentation of the posterior margin.

DESCRIPTION: Medium- to large-sized (large complete holaspid up to $18 \mathrm{~cm}$ in the studied material) trilobites. Cranidium transversely subrectangular, overall convexity modest, length about 70 to $80 \%$ maximum width across centre of palpebral lobes. Glabella moderately convex, length in adult specimens slightly more than $75 \%$ cephalic length; continuously tapers forward. Frontal lobe sagittally short, with shallow anterior curvature. Three pairs of lateral furrows developed, all shallow and progressively indistinct from $\mathrm{S} 1$ to $\mathrm{S} 3$ and progressively more forwardly directed, enhanced in visibility on the exterior of the shell by differences in ornamentation. S3 commences at short distance from dorsal furrows, indistinct. Occipital furrow a wide transverse depression but relatively shallow in median sagittal section, lateral sections deeper and slightly backward-directed from axial furrows, median portion almost straight. Occipital ring up to c. $23 \%$ cephalic length, posterior rim gently curved, with terminal occipital node.

Dorsal furrows moderately wide, very shallow, weakly delimited from fixigenae. Fixigenae faintly convex, subtriangular, exsagittally up to $40 \%$ maximum cephalic length and transversely narrow, less than $20 \%$ maximum cranidial width (across centre of palpebral lobes). Posterolateral projections of fixigenae narrow and laterally extended, slope ventrally. Palpebral lobes slightly convex in large individuals, moderately long and with gentle curvature (less than one-third cephalic length), about 7-9 \% cranidial width and c. 14-17\% maximum glabellar width, weakly oblique to exsagittal axis, posterior tips clearly distant from posterior border furrow in adults. Palpebral furrows narrower (tr.) than palpebral lobes, shallow in large individuals. Eye ridges clearly oblique to axis, directed c. 25 degrees anteriorly from anterior tips of palpebral lobes in adults, forming moderately elevated ridges in small specimens but fading in height both anteroproximally and posterodistally. Eye ridges curve forward adaxially into narrow bands that form a narrow and indistinct parafrontal band anterior to the glabellar front.

Anterior branches of facial suture moderately long, diverge moderately to meet anterolateral border and curve forward toward anterolateral margin, resulting in a long and distinctly adaxially curved anterior section.

Text-fig. 15. 1-7 - Myopsolenites hyperion sp. nov.; all from the Wadi Uhaymir section. 1, 3, 6 - Holotype, FG-602-065, incomplete carapace, dorsal view; 1, entire specimen, natural size; 3 , detail of left anteriormost pleurae showing differences in the anterior margins (due to differential inclination of tergites) and details of articulation, $\times 2 ; 6$, detail of occipital ring and anterior thoracic axial rings, $\times 2 ; 2-$ Paratype, FG-602-058b, incomplete cranidium, dorsal view, with fragments of two additional cranidia (overturned). Note differences in granulation, $\times 2.5$; 4 - Paratype, FG-602-058c, incomplete pygidium, dorsal view, × 1.2; 5, $7-$ Paratype, FG-602-056a, incomplete carapace, dorsal view; 5 , detail of left part of thorax with attached pygidium, $\times 1.7 ; 7$, view of thorax with articulated incomplete pygidium, natural size 
CAMBRIAN TRILOBITES OF JORDAN
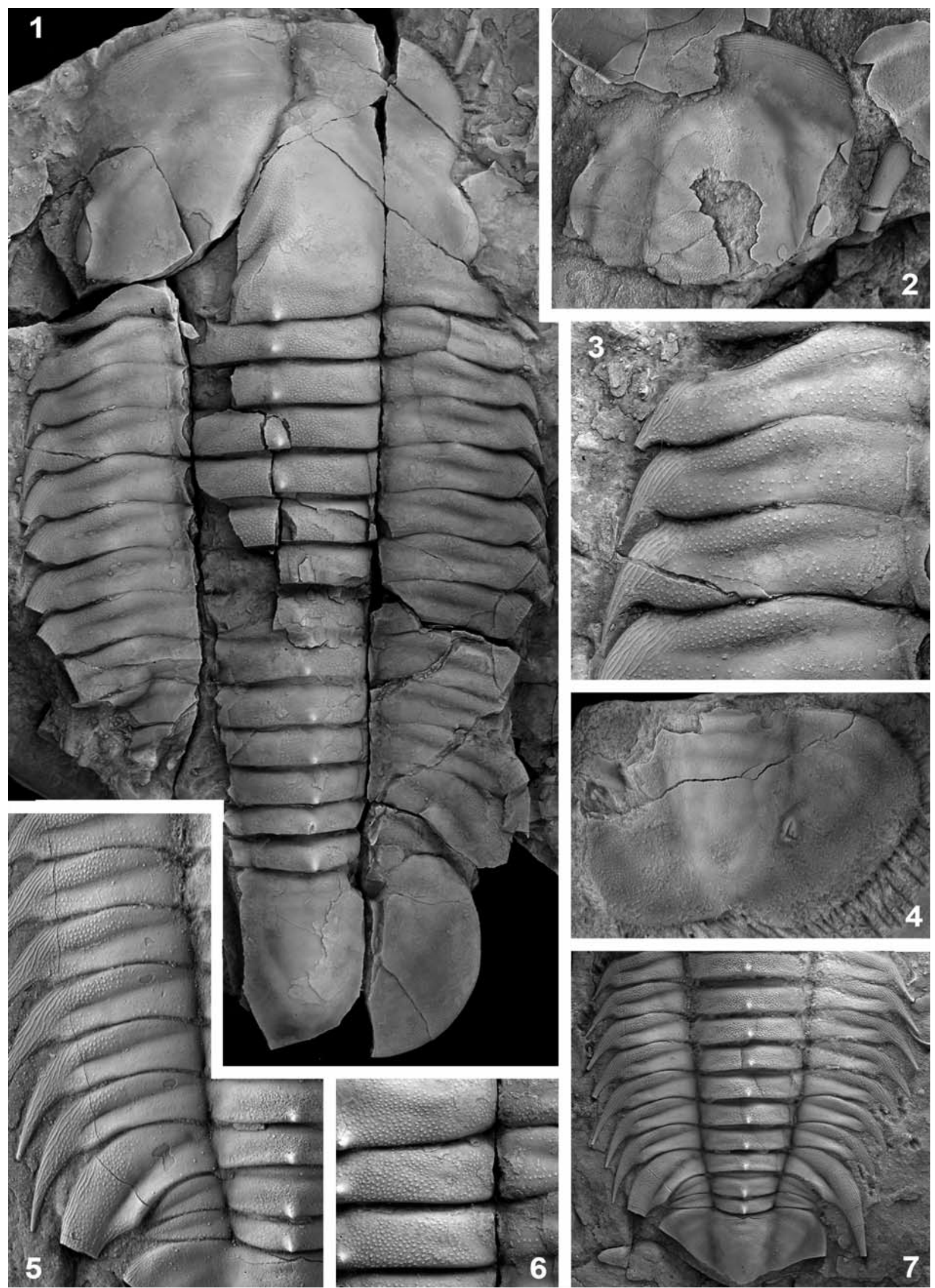
Posterior branches diverge strongly, curve gently from posterior tips of palpebral lobes. Preglabellar field narrow and forms more-or-less a sunken, poorly defined area between glabella and anterior border furrow. Preocular fields shallow, slope ventrally from eye ridges.

Anterior border moderately wide, in front of glabella sag. up to one-tenth cephalic length, fairly low, slightly ascending from preglabellar field. Anterior border furrow shallow to obsolescent. Posterior border moderately wide and moderately convex, adaxial section normal to axis up to a small socket that corresponds to fulcral process at first thoracic segment, then runs somewhat rearward and is dorsally deflected. Posterior border furrow moderately wide close to dorsal furrows, deepens from midway of the fixigenal width.

Thorax of adults consists of thirteen segments. Thorax subdivided by a macropleural segment which always appears to be the third from the rear. Greatest width in normal segments at about fifth segment, progressively tapering backward. Rhachis conical, widest at second or third tergite, progressively tapering backward. Width of axis at first thoracic segment c. $40 \%$ transverse width of first segment, width at fifth segment c. $36 \%$, width at tenth segment c. $32 \%$ thoracic width; axial ring at first segment about as wide as occipital ring.

Axial rings moderately convex in transverse section; consist of wide median portion and fairly indistinct narrow (tr.) anterolateral portions. Median portion sagittally weakly convex, with distinct median node which is spherical on the anterior and middle tergites and faintly and progressively extended sagittally on tergites 10 to 12. Anterior margin of axial ring generally straight or slightly sigmoidal, but with distinct rearward bend in segment 1 and in the terminal segment. Posterior margin generally straight, with a slight forward curvature close to the axial furrows. Doublure often visible due to compression, consists of a moderately wide lenticular strip at the posterior rim of the axial ring. Articulating half-ring moderately wide (sag.) and distinctly convex.

Normal pleurae of anterior tergites with anterior margin straight and normal to axis up to a stout fulcral process about halfway between dorsal furrows and pleural tips, curves rearward abaxially to the fulcral process. Anterolateral portion forms strongly deflected facet abaxial to fulcral socket. Posterior margin of pleurae Sshaped, distal portion slightly swinging forward to form shallow concave area close to the pleural spine, with small dorsoventral flexure half way between dorsal furrow and pleural tip that forms an indistinct socket that corresponds to the fulcral process of the adjacent tergite. Except for tergite 1, fulcral sockets and corresponding processes are in a progressively more adaxial position in posterior tergites. Pleural furrows moderately deep, fairly well defined, widest medially, with progressively lenticular shape posteriorly; abaxial tip slightly distant from base of pleural spine. Pleural tip formed by a relatively strong posterior curvature of the anterolateral margin and a concave curvature of the distal part of the posterior margin which produce a moderately long, fairly backwarddirected pleural spine that grows progressively rearward. Pleurae of first tergite slightly modified, with short abaxial portions terminated by fulcral processes corresponding to cephalic posterior border. Abaxial part of pleurae at first thoracic tergite with strong posterior curvature of anterior margin to form strongly deflected, large facet, rearward curvature of distal posterior margin and a comparatively small pleural spine (Text-fig. 15.3). Pleural furrow with wider area adaxially.

Macropleural eleventh (or sometimes tenth) segment with axial ring comparable in morphology to that in other thoracic segments, distal portions strongly modified: pleurae greatly expanded, with anterior margin of pleurae similar to normal pleurae and posterior margin directed backward from axial furrows; regular forward swing of posterior margin results in an obliquely falcate outline of the distal portion of the pleura; mid-pleural areas attain nearly double (exsag.) width of normal pleurae. Pleural spines extend outward and rearward to almost the level of the posterior tip of the pygidial axis.

Presence of a macropleural segment affects shape of adjacent posteriormost two tergites. Pleurae in first tergite posterior to macropleural segment reduced to small subtriangular or slightly falcate areas with the anterior margins curved but strongly truncate and posterior margins slightly rearward directed; pleural spine absent. Pleurae of posteriormost tergite lanceolate, with slightly curved anterior and posterior margins; pleural spine absent (Text-fig. 15.5).

Pygidium large, subelliptical in outline with median concave indentation of posterior margin in large individuals; length from articulating furrow to posterior margin about two-thirds maximum width (tr.). Lateral margins smooth, diverge from anterolateral corners to reach maximum width about one-fourth distance from anterior margin, then swinging gently inward. Articulating half-ring narrow (sag.).

Axis of almost $90 \%$ pygidial length, with elongate subtriangular outline, consists of semi-fused axial rings, with c. five axial rings recognizable in juvenile specimens, c. three ill-defined rings recognizable in adult specimens, followed by a large terminal axial piece. Posterior part of axis with elevated, chevron-shaped marginal lobe that creates a weakly defined subtriangular depression.

Pleural areas fused to form a relatively homogeneous, weakly convex subtriangular platform. Three to 
four weakly defined interpleural furrows recognizable. Border furrow poorly defined, visible as a slope from pleural fields and a subtle change in convexity towards border. Border low, moderately wide.

Surface of test generally covered with moderately large to large, densely spaced granules without a visible central perforation. Furrows tend to be less densely covered or smooth. The relative size and density of the granules decrease with increasing size of the specimens. Glabellar furrows tend to be smooth in large specimens so that shallow glabellar furrows are often easily recognizable by the differences in the prosopon. More-or-less smooth are the dorsal surfaces of the palpebral lobes. Anterior border covered by long terraces ridges parallel to the anterior margin. Only its posteriormost part shows a slightly transition from terrace ridges to granulation. Remarkably, small but distinct pits are scattered between the terrace ridges (Text-fig. 15.2). These are interpreted herein to have been the location of sensory organs.

The axial rings and thoracic pleurae are covered with granules, whereas the pleural furrows tend to be smooth. The anterior pleural fields carry more and more densely spaced granules than the posterior pleural fields. The pleural spines are covered with obliquely-directed, sparsely dichotomic terraces ridges arranged more-or-less parallel to the anterolateral margin of the pleural spine.

Pygidial axis and pleural fields of the pygidium covered with granules which vary slightly in relative size and density, indicating the pattern of axial furrows. Pygidial border with small and relatively few terrace ridges close to and oblique to the pygidial margin.

ONTOGENY: Five incomplete immature specimens, most probably representing growth stages of Myopsolenites hyperion $\mathrm{sp}$. nov. were recorded. The fragile preservation made an appropriate conservation and documentation impossible although we figure two of the specimens herein (Text-fig. 9.6, 9.7). The thorax of these immature individuals consists of at least 13 segments with tr. wide axial rings of up to more than half thoracic width (except for pleural spines), moderately convex in transverse section, with short median thorn. The pleurae are short, with a transverse width in the anterior tergites equal to about half the width of the axial ring. The pleural furrows are well developed, slightly oblique to the transverse axis, and fade towards the pleural tips so that they do not reach the posterior margins. The pleural tips are obliquely truncated, but develop posteriorly into rearward directed slender spines. The size of the pleural spines grows from short to medium-sized in the anterior six to seven segments to long and progressively backwardly directed in the posterior half of the thorax. The pygidium is moderately large, longitudinally parabolic, has a long and broad axis, but lacks readily recognizable details in the present material.

This morphology very much resembles that of imperfectly preserved material of immature specimens of Bathynotus spp. from South China, such as specimens identified as Bathynotus holopygus from the Kaili Formation of Guizhou (e.g., Yuan et al. 2002, pl. 7, figs 3, 4, and Peng et al. 2009, fig. 1g; see Webster 2009 for critical analysis), providing another clue to a close phylogenetic relationship of Myopsolenites and Bathynotus.

DISCUSSION: Myopsolenites hyperion sp. nov. is a close relative to Myopsolenites altus (Liñán and Gozalo, 1986). In particular, the species share a thorax consisting of a macropleural eleventh segment and wide pleural areas that provide the pygidium with a subparabolic outline. The fine granulation with its fine spatial variation also resembles that seen in well preserved specimens of Myopsolenites altus from the Moroccan Anti-Atlas (Geyer and Landing 2004, fig. 5). However, M. hyperion is clearly distinguished from $M$. altus by its shallow, medially disconnected S1 and a weakly curved front, and by shorter palpebral lobes. The occipital and thoracic rings have subterminal nodes, and the pygidium shows gently curved lateral and posterior margins. Differential growth leads to the presence of a median indentation of the pygidial posterior margin in very large specimens.

Myopsolenites hyperion is clearly distinguished from M. palmeri (Parnes, 1971) by its shorter glabella; by longer palpebral lobes; by transversely shorter thoracic pleurae with shorter pleural spines; by the subtriangular rather than subparabolic outline of the pygidium with more clearly developed furrows; and by the coarser and more regularly arranged granulation of the test.

Myopsolenites palmeri (Parnes, 1971)

(Text-figs 16, 17)

1923. Asaphid; King, p. 511.

v 1971. Myopsolenus palmeri n. sp.; Parnes, p. 202-203, pl. 3, figs 30-31, pl. 4, figs 32-37, ?38, 39, 40.

1975. Myopsolenites palmeri; Öpik: p. 8, caption of fig. 3.

1998. Onaraspis palmeri (Parnes, 1971); Rushton and Powell, p. 140-141, figs 19, 20.

2004. Myopsolenites palmeri (Parnes, 1971); Geyer and Landing, p. 13, 14, 22, 23.

? 2007. Onaraspis sp.; Gozalo et al., fig. 4E, 4I

EMENDED DIAGNOSIS: Species of Myopsolenites with moderately tapering glabella with shallow, medially disconnected $\mathrm{S} 1$ and weakly curved front; palpebral 

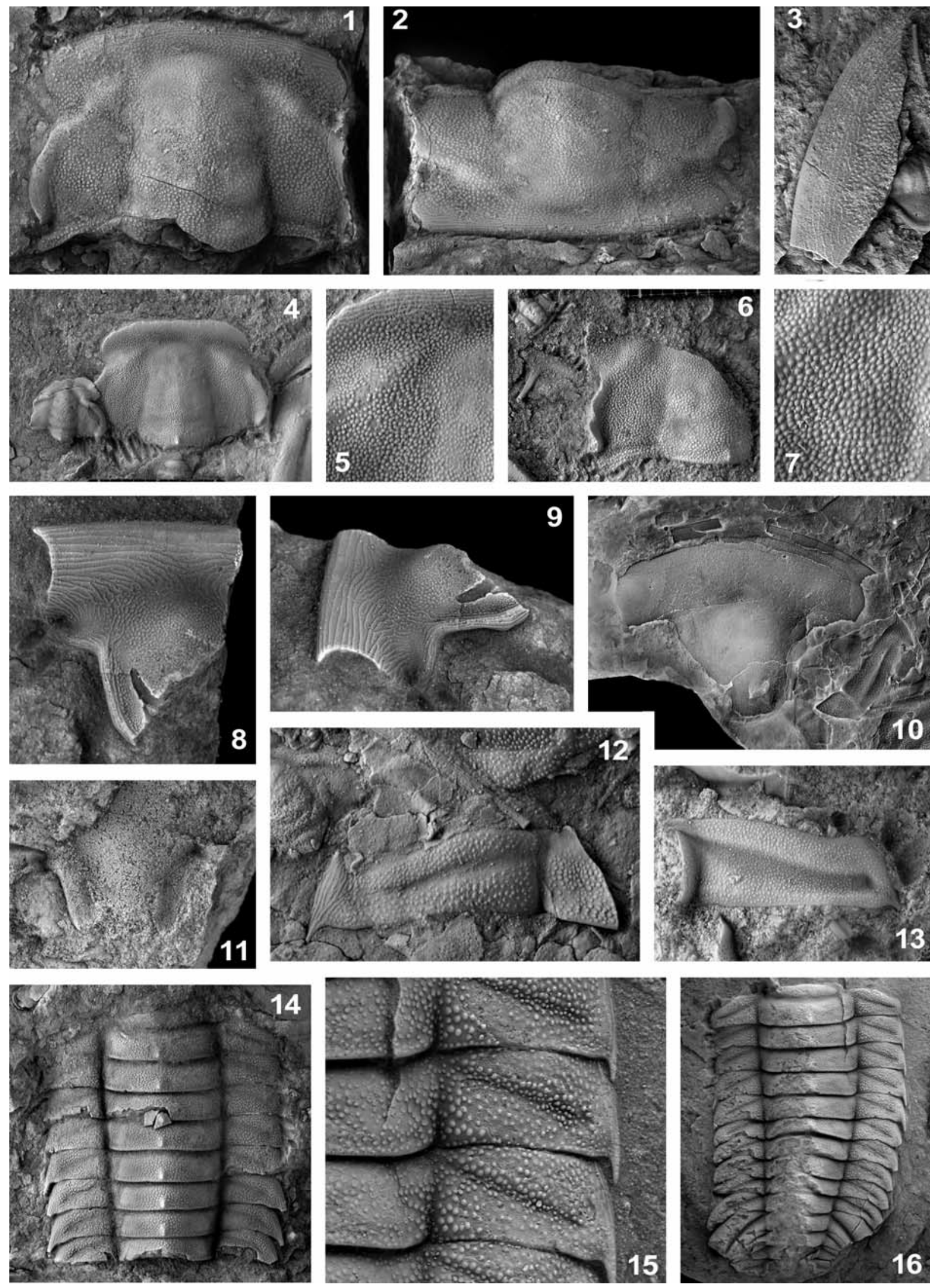

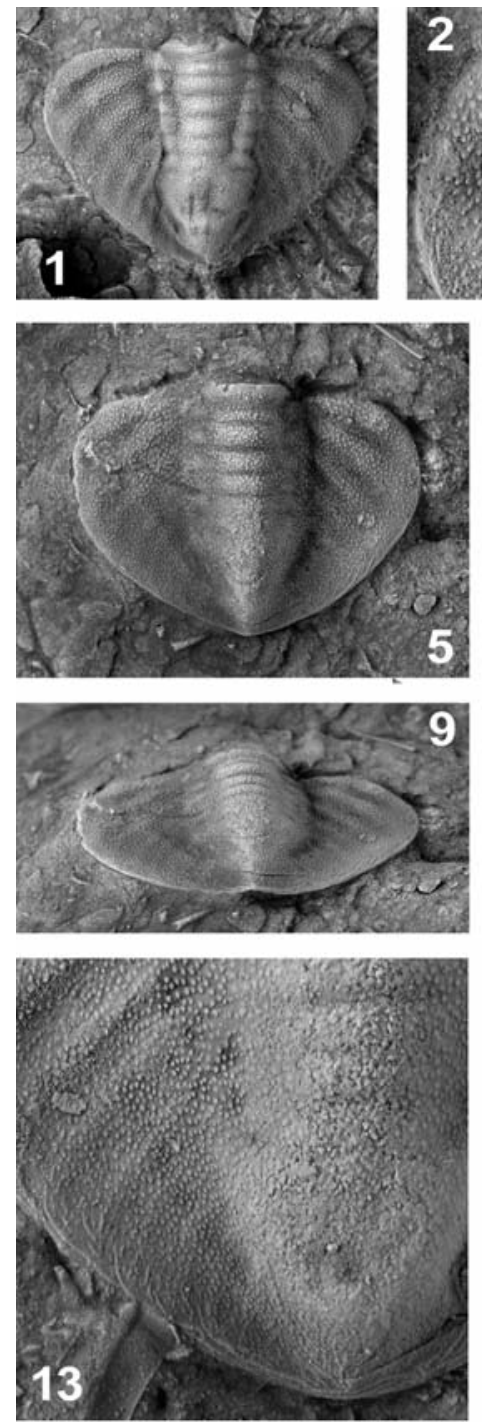
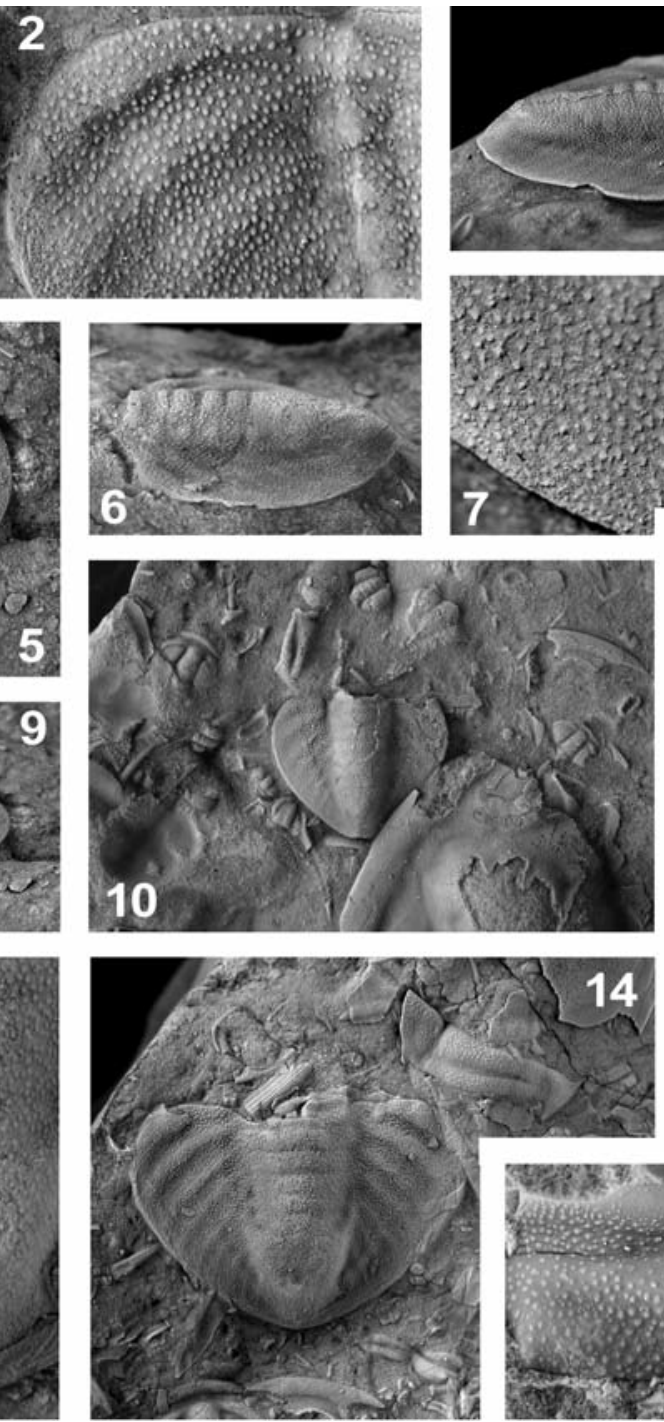
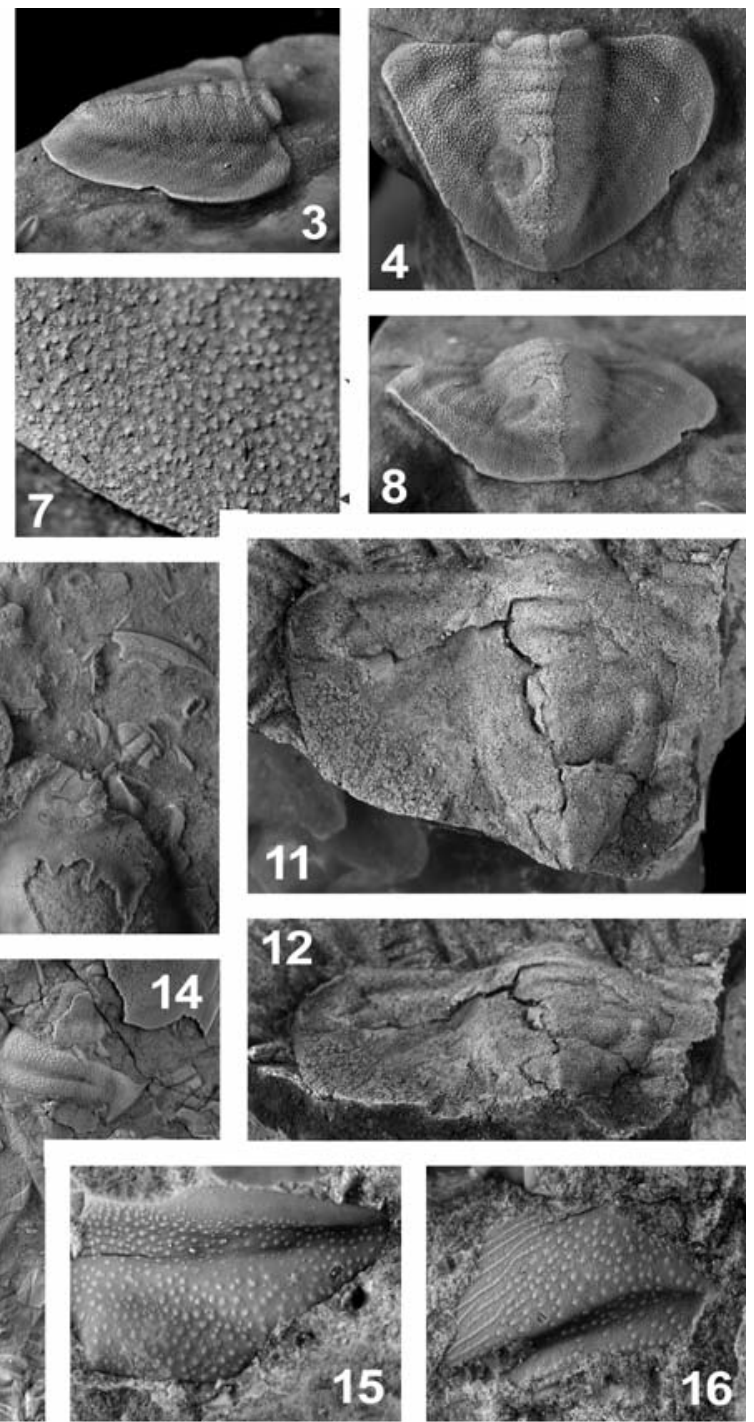

Text-fig. 17. 1-16 - Myopsolenites palmeri (Parnes, 1971). 1,2 - FG-602-021a, pygidium with compressed rhachis, dorsal view, Wadi Uhaymir; 1, entire sclerite, $\times 2$; 2, detail showing prosopon, $\times 5 ; 3,4,8-$ FG-602-010a, incomplete pygidium, right lateral, dorsal and oblique posterior views, Wadi Uhaymir, $\times 2$; 5-7, $9-$ FG-602043a, pygidium, Wadi Uhaymir; 5, dorsal view, $\times 2 ; 6$, left lateral view, $\times 2 ; 7$, detail showing posterolateral pleural region with prosopon of coarse obliquely directed granules, $\times 9$; 9, oblique posterior view, $\times 2 ; 10-$ FG-602-035, slab with incomplete pygidium (FG-602-035a) in the centre, Wadi Uhaymir, $\times 2$; $11-$ FG-602-097, incomplete semigerontic pygidium, preserved in sandstone, partly exfoliated sculptural steinkern, dorsal view, Wadi Issal, × 1.5; 13, 14-FG-602-045a, incomplete cranidium, dorsal view; 13, detail showing prosopon of coarse granules and short, wrinkled terrace ridges oblique to the pygidial margin grading into granules, Wadi Uhaymir, $\times 5$; 14, dorsal view of entire sclerite and fragment of thoracic segment, $\times 2 ; 15,-$ FG-602-004a, fragment of thoracic axial ring, Wadi Uhaymir. Note differences in the nature of the axial furrow and slightly longitudinal course of axial node, $\times 5 ; 16-$ FG-602-007b, fragment of thoracic pleura showing transition from granules to terrace ridges, Wadi Uhaymir, $\times 3$

Text-fig. 16. 1-16 - Myopsolenites palmeri (Parnes, 1971). 1, 2 - FG-602-021b, incomplete cranidium, dorsal and oblique anterior views, Wadi Uhaymir, $\times 2$; 3 FG-602-059, fragment of librigena, dorsal view, Wadi Uhaymir, × 2; 4, 5- FG-602-062b, immature cranidium, dorsal view, Wadi Uhaymir; 4, entire sclerite associated with incomplete cranidium of Redlichops blanckenhorni, $\times 2$; 5, detail showing prosopon of granules and terrace ridges, $\times 5 ; 6,7-\mathrm{FG}-602-062 \mathrm{~d}$, cranidium, dorsal view, Wadi Uhaymir; 6, entire sclerite, $\times 2$; 7, detail, $\times 5 ; 8,9-$ FG-602-010b, incomplete hypostome, dorsal and oblique left lateral views, Wadi Uhaymir, $\times 4 ; 10-$ FG-602-035k, mould of hypostome, ventral view (optically reversed), Wadi Uhaymir, $\times 2$; $11-$ FG-602-054, incomplete hypostome, internal mould preserved in sandstone, dorsal view, Wadi Issal, $\times 2$; 12 - FG-602-035d, fragment of anterior thoracic segment, dorsal view, Wadi Uhaymir, $\times 5$; $13-$ FG-602004, fragment of anterior thoracic segment, dorsal view, Wadi Uhaymir, $\times 5 ; 14-$ FG-602-060a, incomplete thoracic carapace, dorsal view, Wadi Uhaymir, $\times 1.5$. 15, 16 - FG-602-057, incomplete thoracic carapace with short pleurae, dorsal view, Wadi Uhaymir; 15, detail showing short, posteriorly directed pleural spines, $\times$;

16 , entire specimen. Note presence of macropleural segment, $\times 1.5$ 
lobes moderately long in adults; fixigenae moderately wide; adult thorax with thirteen segments; occipital and thoracic rings with posteromedian to subterminal nodes; thoracic pleura transversely short, with small and acute, posteriorly directed spines; pygidium with gently curved lateral and posterior margins, subparabolic to heartshaped in outline; prosopon of coarse granules.

MATERIAL: All specimens collected at the Wadi Uhaymir section, Jordan, unless otherwise noted. Six incomplete cranidia, FG-602-021b, FG-602-045e, FG602-062b, FG-602-062d; one fragment of librigena, FG-602-059c; two incomplete thoraces, FG-602-057, FG-602-060a; four incomplete thoracic segments, FG602-004a, FG-602-004b, FG-602-007b, FG-602035c, g; 7 pygidia, FG-602-010a, FG-602-021a, FG602-035a, FG-602-043a, FG-602-045a, FG-602-097 (Wadi Issal); incomplete rostrohypostomal plates, FG602-010b, FG-602-035k, FG-602-054 (Wadi Issal).

DESCRIPTION: Medium- to large-sized trilobites. Cranidium transversely subrectangular, overall convexity moderate, length c. $70 \%$ maximum width across centre of palpebral lobes. Glabella moderately convex, length in adult specimens more than $85 \%$ cephalic length; continuously tapering forward. Frontal lobe sagittally short, with shallow anterior curvature which is progressively less pronounced with increasing size. Three pairs of lateral furrows, all shallow and progressively indistinct from $\mathrm{S} 1$ to $\mathrm{S} 3$ and progressively more forward directed, enhanced in visibility on the exterior of the shell by differences in ornamentation. S1 commences at dorsal furrows, faintly curved and slightly backwardly directed, clearly separated medially on glabella. S2 commences short distance from dorsal furrows, shallow, more-or-less transverse. S3 commences short distance from dorsal furrows, indistinct, transverse to somewhat forwardly directed. Occipital furrow a wide transverse depression but shallow in median sagittal section, lateral sections deeper and faintly backward-directed from axial furrows, median portion almost straight. Occipital ring up to $23 \%$ cephalic length in adults, posterior rim gently curved in large individuals, with subterminal occipital node.

Dorsal furrows moderately wide, very shallow, weakly delimited from fixigenae. Fixigenae faintly convex, subtriangular, exsagittally up to c. $45 \%$ maximum cephalic length and transversely moderately wide, about $20 \%$ maximum cranidial width (across centre of palpebral lobes). Posterolateral projections of fixigenae narrow and laterally extended, sloping ventrally. Palpebral lobes with slight changes in morphology during ontogeny; slightly convex in large individuals, relatively weakly convex and upturned distally in juveniles; moderately long and with gentle curvature in large individuals (c. $45 \%$ cephalic length); about 5-7\% cranidial width and ca. 11-15\% maximum glabellar width, weakly oblique to exsagittal axis, posterior tips located short distance from posterior border furrow in adults. Palpebral furrows narrower (tr.) than palpebral lobes, shallow. Eye ridges clearly oblique to axes, directed c. 25-30 degrees anteriorly from anterior tips of palpebral lobes, curve forward into narrow bands that form a narrow and indistinct parafrontal band anterior to the glabellar front.

Anterior branches of facial suture moderately long, diverge moderately to meet anterolateral border and curve forward toward anterolateral margin. Posterior branches diverge strongly, curve gently from posterior tips of palpebral lobes. Preglabellar field a narrow sunken area between glabella and anterior border furrow. Preocular fields shallow, slope ventrally from eye ridges.

Anterior border moderately wide, in front of glabella sag. about 7 to $9 \%$ cephalic length, fairly low, slightly ascend from preglabellar field. Anterior border furrow shallow and obsolescent. Posterior border narrow, moderately convex, slightly rearward directed and dorsally deflected. Posterior border furrow moderately wide close to dorsal furrows, poorly defined anteriorly.

Thorax of adults consists of thirteen segments, whereas the holotype from Har 'Amram, southern Negev, has twelve thoracic segments. Thorax subdivided by a macropleural segment which always appears to be the third from the rear. Greatest width in normal segments at about fifth or sixth segment, slightly and progressively tapering backward. Rhachis conical, widest at second or third tergite, progressively tapering rearward. Width of axis at first thoracic segment c. 42$45 \%$ transverse width of first segment, width at fifth segment c. $45-48 \%$, width at tenth segment c. $40 \%$ thoracic width; axial ring at first segment about as wide as occipital ring.

Axial rings moderately convex in transverse section; consist of wide median portion and fairly indistinct narrow (tr.) anterolateral portions. Median portion sagittally weakly convex, with distinct posteromedian node which is spherical on the anterior and middle tergites and faintly and progressively extended sagittally on tergites 10 to 12 (Text-fig. 16.14). Anterior margin of axial ring generally straight or slightly sigmoidal, but with distinct rearward bend in segment 1 . Posterior margin generally straight, with a slight forward curvature close to the axial furrows. Axial furrow with narrow (sag.) lateral and distinctly wider median portion, covered by granules (Text-fig. 16.15). Articulating half-ring relatively wide 
(sag.) and distinctly convex, surprisingly covered by granules in the posteriormost portion (Text-fig. 16.16).

Normal pleurae of anterior tergites with anterior margin straight and normal to axis up to a stout fulcral process about half-distance between dorsal furrows and pleural tips, curving rearward abaxial to the fulcral process. Anterolateral portion forms strongly deflected facet abaxial to fulcral socket. Posterior margin of pleurae faintly S-shaped, distal portion swinging into a very small concave area close to the pleural spine. Fulcral sockets and corresponding processes barely visible in dorsal view, in a progressively adaxial position in posterior tergites. Pleural furrows moderately deep, fairly well defined, widest medially; abaxial tip slightly distant from base of pleural spine. Pleural tip formed by a strong, nearly angular posterior curvature of the anterolateral margin, developing into a short, acute and strongly backward-directed pleural spine (Text-fig. 16.15). Pleurae of first tergite slightly modified, with short abaxial portions terminated by fulcral processes corresponding to cephalic posterior border. Abaxial part of pleurae at first thoracic tergite with strong posterior curvature of anterior margin to form rearward curvature of distal posterior margin and a small pleural spine.

Macropleural eleventh (or sometimes tenth) segment incompletely known from the newly collected material, with axial ring comparable in morphology to that in other thoracic segments, distal portions strongly modified: pleurae greatly expanded, with anterior margin of pleurae similar to normal pleurae and posterior margin directed backward from axial furrows; midpleural areas attain nearly double (exsag.) width of normal pleurae. Presence of a macropleural segment affects shape of adjacent posteriormost two tergites. Pleurae in first tergite posterior to macropleural segment reduced to small subtriangular or slightly falcate areas with the anterior margins curved but strongly truncate and posterior margins slightly rearward directed. Pleurae of posteriormost tergite obviously lanceolate, with slightly curved anterior and posterior margins.

Pygidium large, subsemicircular to heart-shaped in outline; length from articulating furrow to posterior margin about three-quarters maximum width (tr.). Lateral margins diverge from anterolateral corners to reach maximum width about quarter distance from anterior margin, then swinging rapidly inward and with generally low curvature of the posterolateral sections. Articulating half-ring narrow (sag.).

Axis almost $95 \%$ pygidial length, slightly tapering rearward in the anterior half, but with more strongly conical terminal axial piece. About six axial rings recognizable, consisting of normal ribbon-like sections sep- arated by shallow transverse furrows which are often poorly recognizable on the shell exterior, and nodular lateral sections. Terminal axial piece with chevronshaped marginal lobe that creates a shallow subtriangular depression.

Pleural areas narrow, subtriangular. Five to six low pleural ribs recognizable. Border furrow poorly defined, visible as a slope from pleural fields and a subtle change in convexity towards border. Border low, moderately wide.

Rostrohypostomal plate with broadly connected rostral and hypostomal units. Rostral plate highly convex in sag. direction, slightly constricted medially; lateral sutures parallel or slightly diverging forward. Hypostome slightly tapering backward. Lateral border convex, moderately broad (tr.), swings distinctly distally and ventrally to meet lateral sutures; delimited from posterior border by inconspicuous nodular swellings and a slight change in direction; posterior border imperfectly preserved in the present specimens, convex, parallels gentle curvature of the posterior margin. Lateral and posterior border furrows moderately deep and moderately broad. Hypostomal middle body consists of large more-or-less elliptical anterior lobe and much smaller crescent-shaped posterior lobe, separated by a shallow, weakly defined furrow; with pair of maculae at anterior section of middle furrow. Anterior part of hypostome developed as a broad (sag.), curved depression between rostral plate and middle body.

Surface of test generally covered with relatively large, densely spaced granules. These granules are relatively high, but do not show any central perforation. Furrows tend to be less densely covered or smooth. The relative size and density decreases with increasing size of the specimens. Glabellar furrows are covered with slightly smaller and slightly less densely arranged granules so that the shallow glabellar furrows are often more easily recognizable by the differences in the prosopon than by its actual topographic alteration. Dorsal surfaces of the palpebral lobes more-or-less smooth. The anterior border is covered by long terraces ridges parallel to the anterior margin. Only its posteriormost part shows a slightly transition from terrace ridges to granulation. The rostral plate carries coarse terrace ridges parallel to the anterior margin. The hypostomal middle body and border furrows are covered by granules, lateral and posterior border by terrace ridges. The sunken connective area between hypostome and rostal plate shows a progressive development from granules via branched ridges in a fingerprint-type manner to the parallel terrace ridges on the rostral plate.

Axial rings and thoracic pleurae covered with granules, whereas the pleural furrows tend to be smooth. The 
pleural spines are covered with obliquely directed, sparsely dichotomic terraces ridges.

The pygidial axis and the pleural fields of the pygidium are covered with granules which vary slightly in relative size and density, indicating the pattern of axial furrows. Some specimens show a distinct oblique rearward direction of the granular tips. The pygidial border shows short, wrinkled terrace ridges strongly oblique to the pygidial margin grading into granules of the normal prosopon (Text-fig. 16.13).

DISCUSSION: The new material of Myopsolenites palmeri from Jordan shows several morphological details which were unknown in the type material and which help to define the species more precisely. These include the pattern of the glabellar furrows, the morphology of the thoracic segments and the pygidial axis, and the detailed morphology of the prosopon/ornamentation of the test. All these are described above and need no repetition here. Several aspects have been inaccurately described earlier and necessitate a modification of the species' diagnostic features. They include the number of thoracic segments. The holotype from the Timna area is a carapace with 12 thoracic segments only. Complete individuals from the newly described Jordanian material have 13 segments so that the number varies as in the ontogeny of Myopsolenites altus. Another character not seen properly in the material from southern Israel is the morphology of the node on the occipital ring and the axial rings. Myopsolenites altus has a large median node extending sagittally to form a short ridge. Myopsolenites palmeri, in contrast, has on the anterior and middle part normal median nodes with a circular shape and without a sagittal extension relatively close to but not directly at the posterior margin. In the posterior thoracic segments, the nodes show a weak but progressive tendency toward a longitudinal elongation (Text-fig. 16.14).

The differences from Myopsolenites hyperion sp. nov. have been listed above under the discussion of that species. A closer morphologic relationship appears to exist with Myopsolenites kielcensis (Bednarczyk, 1970). This species is from the lowermost traditional Middle Cambrian of the Świętokrzyskie (Holy Cross) Mountains in Poland and was originally described as Jakutus? kielcensis. It has been based only on two incomplete cranidia with a surface granulation and a single heart-shaped pygidium (Bednarczyk 1970, pl. 2, figs 1-3). The species has been assigned to Myopsolenites by Geyer and Landing (2004) and redescribed by Żylińska and Masiak (2007). Striking differences between M. palmeri and M. kielcensis exist in the broader, more strongly tapering glabella with a clearly recog- nizable L1 and a deeper occipital furrow in M. kielcensis; distinctly shorter palpebral lobes in the species from the Holy Cross Mountains; and narrower fixigenae. The pygidium of $M$. kielciensis is much narrower and has better developed furrows.

Gozalo et al. (2007, fig. 4E, 4I) and Dies Álvarez et al. (2007, fig. 3C, 3E) figured as Onaraspis aff. kielcensis a fragmentary cranidium from the Valdoré section, Cantabrian Mountains, which shares most of the recognizable characters with Myopsolenites palmeri. Unfortunately, the slight distortion and incomplete preservation does not permit a confident determination.

Genus and species indeterminate 1

(Text-fig. 18)

MATERIAL: Single incomplete thorax, FG-602-061a, from the Wadi Uhaymir locality, Jordan.

DESCRIPTION: Incomplete thorax of 16 segments, divided into anterothoracic and opisthothoracic section by macropleural segments and differences in width of the rhachis. Axial rings generally moderately convex in transverse section; composed of broad median portion and slightly swollen narrow (tr.) lateral portions. Lateral portions clearly recognizable in the anterothoracic segments, indicating the attachment sites of strong

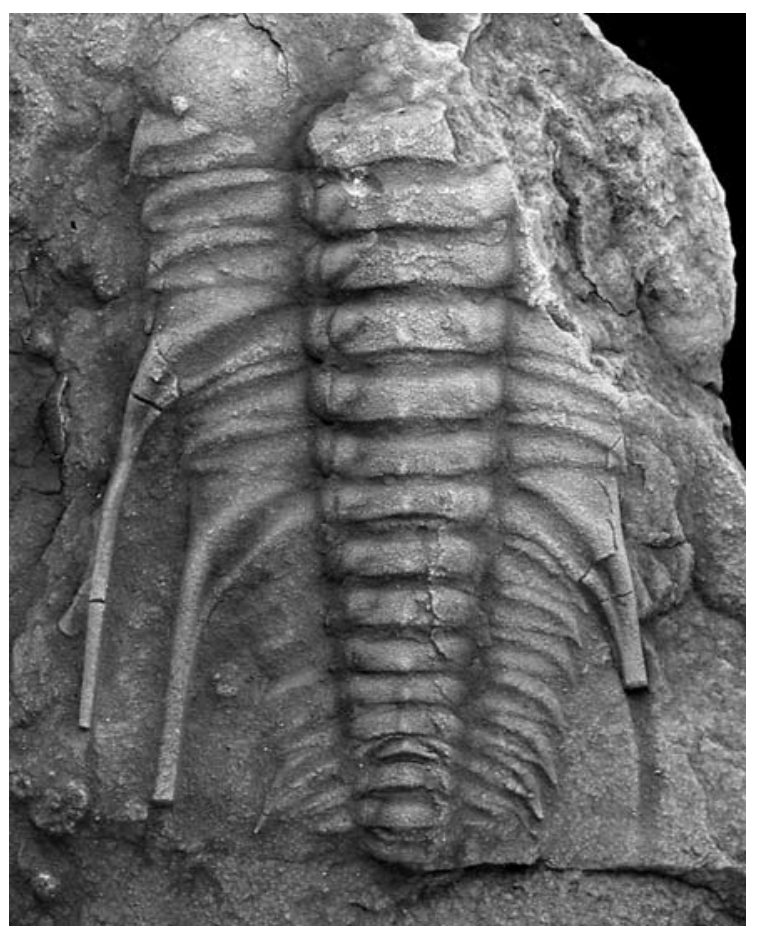

Text-fig. 18. Genus and species indeterminate 1; FG-602-061a, incomplete thorax, Wadi Uhaymir locality, dorsal view, $\times 3$ 
dorsoventral muscles. Median portion sagittally weakly convex, with distinct slightly longitudinally elongate posteromedian node. Anterior margin of axial ring generally straight or slightly sigmoidal, but with a notable rearward bend in segments 1 through 3 . Posterior margin almost straight, with a forward curvature close to the axial furrows. Articulating half-ring sag. narrow where visible in the present specimen.

Anterothorax in the present specimen composed of 7 segments. Segment 1 through segment 3 with axial ring of c. $40 \%$ total transverse width of the segment; pleurae with anterior margin straight and normal to axis up to a stout fulcral process about half-distance between dorsal furrows and pleural tips. Anterolateral portion forms small facet. Posterior margins of pleurae slightly S-shaped, distal portion swinging into a very small concave area close to the pleural spine. Pleural furrows moderately deep, fairly well defined, widest medially; abaxial tip short distance from base of pleural spine. Pleural tip formed by a strong posterior curvature of the anterolateral margin, developing into a short, acute and strongly backward-directed pleural spine. Segment 4 macropleural, with axial ring similar in morphology to that in the thoracic segments anterior to it, distal portions modified to greatly expanded pleurae, with anterior margin nearly straight and normal to axis, posterior margin curved backward from axial furrows and extended into posterior margin of long pleural spine; abaxial exsag. width of pleural areas nearly twice the width at axial furrow; pleural furrow extended into the base of the pleural spine, defined anteriorly by a toruslike ridge which drops markedly to a low anterolateral part of the pleura with a sharply angular tip; pleural spines incompletely preserved, most probably extending backward with tips beyond the level of the pygidium. This macropleural $4^{\text {th }}$ segment affects the shape of the adjacent segment 5 , the pleurae of which are reduced to acute subtriangular or slightly falcate areas with the anterior margins slightly curved; posterior margins directed slightly rearward. Pleural tips of segment 5 form short thorns. Segment 6 of nearly normal morphology, with slightly backwardly directed anterior margins of the pleurae and pleural spines short and thorn-like. Segment 7 macropleural; axial ring similar in morphology to that in the thoracic segments anterior to it, but with slightly median forward bend of the posterior margin; distal portions of pleurae strongly expanded, anterior margin nearly straight and normal to axis, posterior margin curved backward from axial furrows in a shallow curvature to the long pleural spine; abaxial exsag. width of pleura areas more than twice the width at axial furrow; pleural furrow falcate, extended into the base of the pleural spine, defined anteriorly by a torus- like ridge which drops markedly to a low anterolateral part of the pleura with a sharply angular tip.

Opisthothorax in the present specimen composed of eight segments, all of them clearly narrower (tr.) than those of the anterothorax, its axis rapidly tapering from thoracic segment 8 rearward to a subparallel posterior section of the rhachis. Anterolateral swollen areas of axial rings less conspicuous than in the anterothorax. Segment 8 with acutely subtriangular or slightly falcate pleurae, which are directed slightly rearward; its anterior margins slightly curved, posterior margins directed slightly rearward; pleural tips of segment 8 extended into short thorns, delimited from posterior pleural margin by a shallow notch. Segment 9 through segment 16 with axial rings of c. $45 \%$ total transverse width of the segment. Pleurae with anterior margin directed slightly backward, curved to extend into short to moderately long posterolaterally directed pleural spines; posterior margins of pleurae directed faintly backward, straight to slightly S-shaped, distal portion swinging into a small concave area close to the pleural spine or forming an indistinct notch. Pleural furrows moderately deep, fairly well defined; abaxial tip extend into the base of the pleural spine and end short distance from posterior margin. Pleural spines directed posterolaterally, but with a progressively rearward direction from segment 9 through 16.

Surface covered by fine granules.

DISCUSSION: The single specimen is characterized by its two macropleural spines. Such a morphology is only known from genera that are otherwise clearly differentiated from the specimen by the majority of morphological criteria, and which are unknown from this part of the Cambrian world.

Other characters include: a relatively straight abaxial margin of the 'ordinary' pleurae extended into a short, bristle-type pleural spine; a subterminal elongate pleural node; bulbous anterolateral portions of the axial rings; and a prosopon of small granules. These characters are found, at least partly, in the two species of $M y$ opsolenites described above. The pleural morphology of specimen FG-602-061a matches Myopsolenites palmeri (Parnes, 1971), which, however, does not show a macropleural segment and is easily distinguished by other characters such as a broader axis, etc. Myopsolenites hyperion sp. nov. has one macropleural segment, but in a more posterior position, and has a different type of articulation leading to another shape of the pleural tips.

The size of specimen FG-602-061a indicates that it is much smaller than the adult individuals of all known species of Myopsolenites, but still too large to 
show an ontogenetic stage early enough to explain such differences in thoracic morphology. The specimen does not provide any clues for an unusual morphological expression induced by external factors or for a unique individual mutation. As long as no cephala and pygidia are known, it has to be considered that it represents a bathyurid genus and species which is not formally described.

\section{Family Palaeolenidae Hupé, 1953}

Enixus Ödikmen, 2009

(syn. Schistocephalus Chernysheva, 1956)

NOMENCLATURAL NOTE: Schistocephalus Chernysheva, 1956 is a junior homonym of Schistocephalus Creplin, 1829, a Recent cestode tapeworm (Plathyhelminthes, Cestoda) of the Order Pseudophyllidea living on fish, fish-eating birds and rodents. Ödikmen (2009) proposed replacing the generic name for the trilobites by Enixus.

DISCUSSION: The genus Schistocephalus Chernysheva, 1956, long a traditional genus of index fossils in Siberia and the Sayan-Altay Fold Belt, has been revised and is now often treated as a junior synonym of Palaeolenus Mansuy, 1912. The type species of Enixus, E. enigmaticus (Chernysheva, 1956), has a distinct morphology with an almost parallel-sided (or subtly expanding) glabella and four pairs of glabellar furrows, all of them more or less connected over the glabellar midline, and with S3 and S4 much more closely spaced than the others. Other described species of Enixus such as E. juvenis (Chernysheva, 1956), or E. amzassiensis (Fedyanina, 1971) (in Chernysheva 1971) agree well with this morphology. Others, such as E. antiquus (Chernysheva, 1956), E. tchernishevae (Bognibova, 1971) (in Chernysheva 1971), and E.? ornatus (Geyer, 1998), differ in having a clearly expanding glabella with the glabellar furrows not joined over the midline.

How far this disparity in morphology requires a taxonomic separation is a matter of debate and personal opinion. As long as lumping of taxa under genera with wide morphological concepts is not used for precise correlation by means of the species furnished under these genera, this modus operandi is equally proficient than splitting the organismic world into small compartments. Nevertheless, small units have, a priori, the benefit to provide a plain view of the morphological characteristics of its members. However, the situation becomes difficult to handle if a broad morpholog- ical concept is applied and forces a chain of subsequent synonymizations. Unfortunately, this happened in the case of relatives of Enixus.

A first step was the amalgamation of Palaeolenus Mansuy, 1912 and Megapalaeolenus Zhang, 1966, both genera being typical of the traditional LowerMiddle Cambrian boundary interval in South China. In fact, Megapalaeolenus was first thought to be an ancestor of Palaeolenus. There is indeed a morphological series leading towards the Palaeolenus morphology, which forced authors such as Lin and Peng (2004) and Luo et al. (2007) to regard Megapalaeolenus as a junior synonym of Palaeolenus. The distinction between Megapalaeolenus and Palaeolenus was mainly based on the differences between a clavate and an almost subparallel shape of the glabella. This concept was primarily affected by erroneous assignments of species with subparallel glabellas such as Megapalaeolenus magnus Zhu, 1980 (in Zhang et al. 1980), M. expansus Zhang and Zhu, 1980 (in Zhang et al. 1980) and M. longispinus Zhang and Zhu, 1980 (in Zhang et al. 1980). The species in total show a gradual morphological development which parallels differences between the species furnished under Enixus/Schistocephalus: the species of Enixus show a similar morphological shift during their eveolution, but starts in Siberia with earlier species having a clavate glabella to later species with a glabella with subparallel sides. It is thus logical either to unite all three genera under Palaeolenus, or to maintain two separate genera: those with a club-shaped glabella and separated glabellar furrows under Megapalaeolenus, and those with fairly parallel-sided glabellas and transglabellar furrows under Palaeolenus (with Enixus/ Schistocephalus as a younger synonym). However, the situation is not readily applicable and complicated insofar as the expected morphocline in Siberia does not match that in South China, but appears to be reversed. Consequently, the stratigraphic order of Palaeolenustype triobites in South China and Siberia may also be interpreted as a phylogenetic lineage from Palaeolenus and related genera via Megapalaeolenus to Schistocephalus.

In addition, the concept of lumping all of the abovementioned genera under Palaeolenus does not pay much attention to the specific convexity, or relief, of the carapace. Logically, a reduced relief affects the expression or implementation of certain characters so that gradual reduction of the relief may lead to convergent morphological characterization. In this context, it needs to be emphasized that Gigoutella Hupé, 1953 is certainly related to Palaeolenus and Enixus, but synonymizing the genus with Palaeolenus as tentatively suggested by Lin and Peng (2004), Gozalo et al. (2007), and Yuan et al. 
(2009) means to ignoring clear differences in convexity. The situation is further complicated by species such as Palaeolenus medius (Bednarczyk, 1970) from the Paradoxides insularis Zone of the Holy Cross Mountains, Poland, which has a Palaeolenus-type configuration but represents another, somewhat deviant morphotype (compare Żylińska and Masiak 2007).

An even more delicate problem not discussed earlier is that pygidia are not known from the Siberian material, but are from the Chinese genus Palaeolenus (s. str.). These pygidia are small, trapezoidal, and have a large axis. Rushton and Powell (1998) figured a cranidial fragment from the Wadi Zerqa Ma'in section which morphologically agrees fairly well with the Chinese pygidia.

As an example of the resulting mantraps, the synonymization of Enixus/Schistocephalus with Palaeolenus was used by Yuan et al. (2009, p. 218) to correlate the occurrences of Enixus antiquus on the Siberian Platform with those of Palaeolenus/Megapalaeolenus deprati in South China. The authors thus suggested that "the base of the Amgan Stage can roughly correlate with the upper part of the Megapalaeolenus Zone or Arthricocephalus chauveaui Zone in South China", which is incorrect as shown by other, more reliable biostratigraphic data (see Geyer and Peel 2011).

The problem of elaborating the most suitable taxonomic concept for the group is difficult and exceeds the scope of this study. However, lumping all species of Enixus together with Megapalaeolenus and Gigoutella under Palaeolenus certainly does not satisfy the phylogenetic progressions of the clade. Therefore, it appears to be the most sensible solution to retain Enixus for the moment as an independent genus.

Enixus cf. antiquus (Chernysheva, 1956)

(Text-fig. 19)

1998. Palaeolenus antiquus (Chernysheva, 1956); Rushton and Powell, p. 143-145, figs 29-38.

v 2007. Palaeolenus antiquus (Chernysheva, 1956); Shinaq and Elicki, p. 255, 256, 259, 263, fig. 7.2.

2007. Palaeolenus antiquus (Chernysheva, 1956); Gozalo et al., p. 366.

2007. Palaeolenus antiquus; Dies Álvarez et al., p. 426.

MATERIAL: 13 cranidia and cranidial fragments, reposited under FG-602-036a, FG-602-036b, FG602-047a, FG-602-47c, FG-602-048b, FG-602-073, FG-602-082a, FG-602-083a, FG-602-094a; several fragments of thoracic segments. All specimens from the Wadi Zerqa Ma'in locality, Jordan.
DESCRIPTION: Cranidium slightly wider than long, length/width ratio c. 0.92 to 0.94 in adults. Axial furrows shallow on the shell exterior, moderately deep on internal moulds, weakly delimited against fixigenae, tapering forward.

Glabella somewhat clavate, maximum width 1.25 times occipital width in large specimens; length reaches $85 \%$ of cephalic length in adults, width across occipital ring slightly less than $40 \%$ cranidial width across centre of palpebral lobes. Glabella moderately convex, frontal lobe rounded, but some large specimens with a clearly shallower section medially (Text-fig. 19.2); four pairs of moderately well impressed lateral glabellar furrows: S1 relatively wide, with clear onset at axial furrows, with slightly rearward bend, weakly bifurcated medially but only connected medially by shallow depression; S2 narrower than S1, slightly curved, in total view normal to axis, deepest slightly distant from axial furrows, disconnected medially; S3 shallow on shell exterior but clearly visible on internal moulds, directed slightly forward, commencing slightly distant from axial furrows, disconnected medially and ending in shallow drop-shaped depression that suggests short bifurcation sections; S4 short but clearly recognizable on both exterior and interior of the shell, directed slightly forward, commencing at axial furrows, at short distance from and with only small angle against S3. Frontal lobe with two faint parafrontal lobes, both recognizable with certainty on internal moulds only; anterior one narrowing, complete, commencing short distance anterior to eye ridges and surrounding entire front with about equal breadth; second parafrontal lobe posterior to anterior one, thus in a slightly more elevated position, wider, recognizable on well preserved internal moulds only. Occipital furrow more or less straight, with wider median section that suggests slight forward bend medially. Occipital ring moderately long (sagittal length 11-14\% cephalic length), without medial node or with only faint tubercle.

Fixigenae subelliptical in outline; maximum width about $60 \%$ width of occipital ring, maximum length about 36 to $38 \%$ of cephalic length. Palpebral lobe relatively narrow, moderately convex in transverse section, a moderately curved arc of about equal width throughout; posterior end obliquely clipped. Palpebral furrow a narrow crescent-shaped groove, which extends to about double the palpebral lobe width in the centre (opposite L2); extends anteriorly with a faint kink into a shallow and weakly defined furrow that delimits the palpebral lobes against fixigenae; shallow groove runs from this sharp bend toward the anterior facial suture and separates palpebral lobe from eye ridge. Eye ridge exsagittally about as wide as palpebral 

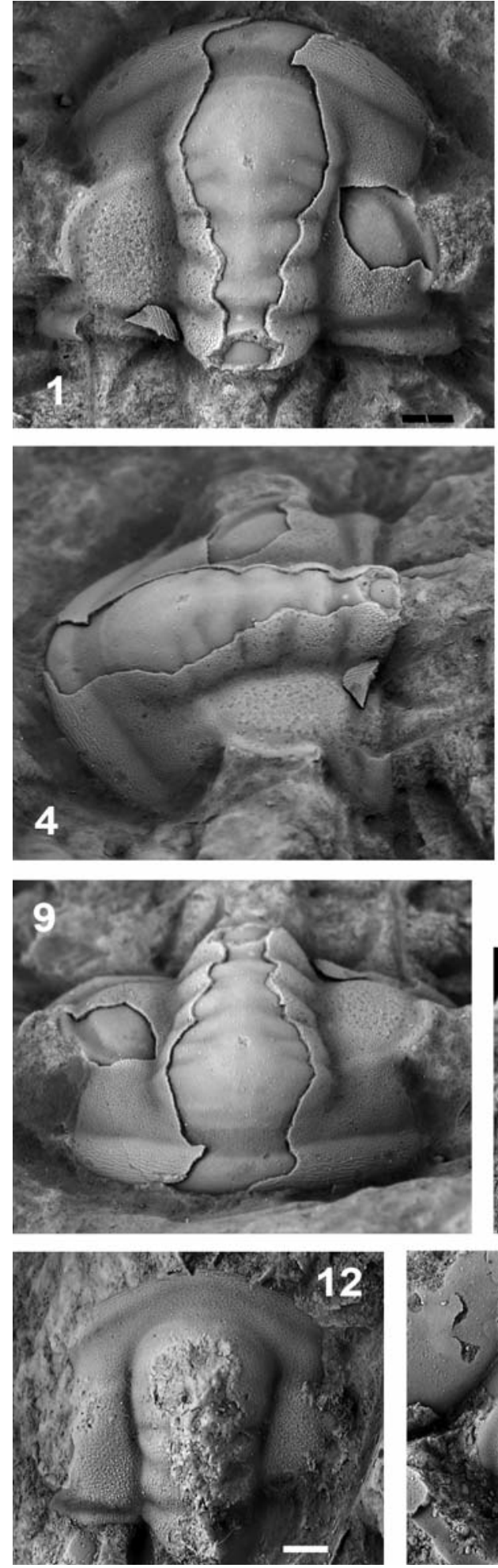
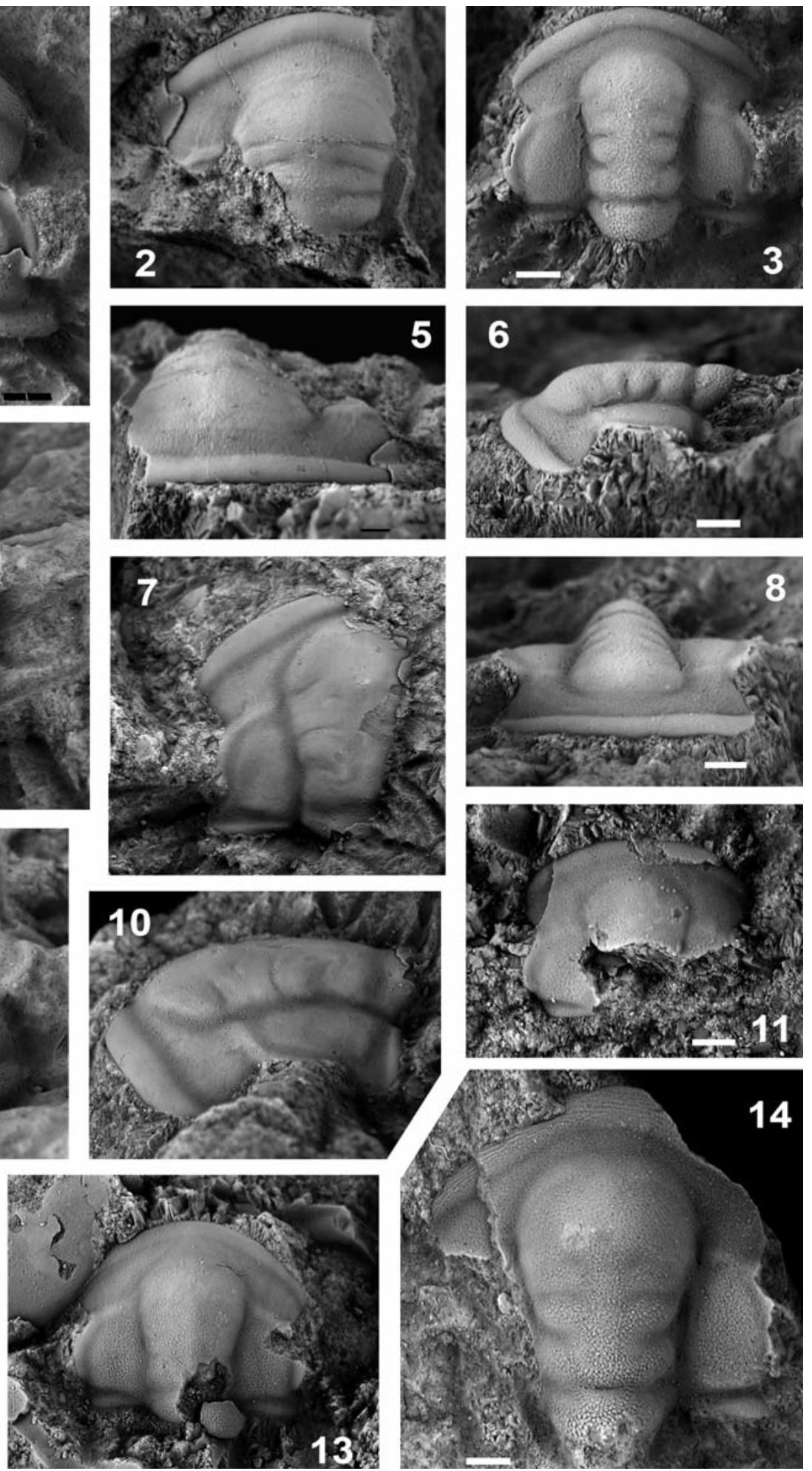

Text-fig. 19. 1-14 - Enixus cf. antiquus (Chernysheva, 1956); all specimens from the Wadi Zerqa Ma'in locality. 1, 4, 9-FG-602-073, cranidium, partly exfoliated, dorsal, left lateral and anterior views. Note vascular threads on anterior part of frontal lobe, $\times 3 ; 2,5-$ FG-602-094, cranidial fragment of individual with unusually broad frontal lobe, dorsal and anterior views, $\times 6 ; 3,6,8-$ FG-602-082a, immature cranidium, dorsal, left lateral and anterior views, $\times 6$; 7, 10 - FG-602-048b, partial cranidium, internal mould, dorsal and left lateral views, $\times 4$; $11-$ FG-602-047c, fragmentary cranidium of juvenile specimen, largely exfoliated, dorsal view, $\times 6$; $12-$ FG-602-036b, incomplete small cranidium, dorsal view, $\times$ 6; 13 - FG-602-047a, incomplete cranidium of juvenile specimen, dorsal view, $\times$ 6; $14-$ FG-602-036a, incomplete cranidium of immature specimen, dorsal view, $\times 6$ 
lobe, weakly arched against palpebral lobe; clearly oblique to axis and faintly curved, faintly bilobate with a slightly narrower (exsag.) anterior section (recognizable on well preserved internal moulds only); distinguished from preocular field by greater relief and a marked slope.

Anterior branches of facial suture diverge moderately, ventrally inclined, slightly curved toward sagittal line from half-distance to border furrow and with a distinct curvature towards sagittal line midway through anterior border (which thus suffers a distinct cut-off anteriorly). Anterior wings thus extend slightly less distally than palpebral lobes (despite specimens with seemingly more widely extending wings which are affected). Posterior branches of facial suture diverge strongly, are moderately curved, clearly ventrally deflected, extend more distally than palpebral lobes.

Preglabellar field in front of glabella slightly narrower that anterior border. Preocular fields more than twice as wide as anterior border, with distinct slope from eye ridges, and with low convexity.

Anterior border does not fit into the general convexity of the cephalon; surrounds preglabellar field and preocular fields as a low to moderately raised ribbon with weakly convex surface; tapers slightly toward facial suture due to long clipped portions near margin. Anterior border furrow appears moderately sharp, but is shallow, slightly better defined laterally. Posterior margin of cranidium slightly S-shaped; posterior border slightly broader distally. Posterior border furrow deep near dorsal furrow, widens distally, and runs slightly oblique to axis.

Exterior of test finely and densely punctuate, and with irregularly spaced, small granules on elevated areas of the cranidium such as glabella (except furrows), fixigenae, eye ridges, and posterior border. Anterior border with terrace lines in the anterior half. Preglabellar field and adaxial parts of preocular fields on interior of test with faint, densely spaced radially arranged caeca (visible on well preserved internal moulds only). Larger imprints of vessels occasionally visible, commencing from anterior of eye ridges (Text-fig. 19.2, 19.5).

Pygidium known only from very incomplete sclerites, small, subelliptical in outline, length to width ratio presumably c. 0.6 .

Axis highly convex, stout, tapers rearward and reaches posterior border furrows; length c. $85 \%$ of pygidial length. Terminal axial piece rounded posteriorly, about half axial length, with a pair of low protuberances about half-length and a shallow median depression close to the posterior margin. Two obvious axial rings defined by sharp transverse furrows. Width of axis slightly less than two-thirds pygidial width.
Pleural fields convex, with two pairs of well-impressed interpleural furrows. Pleural furrows shallow. Border furrow shallow and weakly delimited. Border low, poorly defined, weakly convex.

ONTOGENETIC VARIABILITY: Immature specimens of Enixus cf. antiquus differ from large adult specimens mainly in the relative proportions. The most conspicuous differences of the juveniles (compared to adults) are:

Glabella highly elevated, sagittally of $83-86 \%$ cephalic length. Glabellar furrows less impressed on the shell exterior. Relative length of frontal lobe larger than in adults. Transverse width across L1 c. $77-81 \%$ width across frontal lobe (c. 74-78 \% in large individuals). Anterior border in immature specimens more strongly elevated and sag. and exsag. broader than in adults.

DISCUSSION: The material from Wadi Zerqa Ma'in provides an ontogenetic series of cranidia which clearly defines a distinct form of Enixus Ödikmen, 2009 (= Schistocephalus Chernysheva, 1956). It has been discussed earlier (Geyer 1998, p. 383) that Enixus was known from material of the Siberian Platform and the adjacent regions long before it was found in the Moroccan Atlas region (Geyer 1998) and in the Dead Sea area of Jordan (Rushton and Powell 1998). If the type species of Enixus, E. enigmaticus (Chernysheva, 1956), is taken as the paradigm of the morphology of the genus, both the Moroccan and the Jordanian material is not particularly typical of Enixus, and neither are some of the Siberian species assigned to Enixus. The enigmaticus clade is characterized by lateral glabellar furrows S3 and S4 that are closely spaced and well developed close to the midline of the glabella, whereas the antiquus clade has the lateral glabellar furrows best developed close to the axial furrows. Among the latter is Enixus antiquus (Chernysheva, 1956), introduced by Chernysheva (1956) with the type species and now index fossil of the lower Amgan Enixus antiquus Zone, which defines the basal Middle Cambrian in the Siberian Anabar-Sinsk facies region. Both the Moroccan and the Jordanian specimens differ markedly from the type species, E. enigmaticus, but are at least similar to E. antiquus. Geyer (1998) has contributed to this fact and assigned the Moroccan species E. ornatus (Geyer, 1998) to the genus with proviso only.

Rushton and Powell (1998) identified the Jordanian material as "Palaeolenus antiquus", which not only greatly facilitates the correlation from Jordan to Siberia, but also provides a correlation tool into the South China continent. Indeed, the holotype selected by Chernysheva (1956; see Sdzuy 1995, pl. 1, fig, 9) is similar to large 
specimens from the Wadi Zerqa Ma'in locality. The specimens from Jordan are so similar to a few of the Siberian specimens described from the River Amga sections (e.g., Chernysheva 1961, pl. 3, fig. 2) that this identification appears to be well justified at first glance. A major problem remains in that the Siberian material of Enixus antiquus is quite heterogeneous. The vast majority of the specimens described and figured as E. antiquus (compare e.g., Egorova et al. 1976, pl. 23, figs 1114 , pl. 25 , figs 1,2 , pl. 28 , fig. 1) have an only weakly clavate glabella with a much less expanded frontal portion, its lateral sides moderately diverging forward to form a club-shaped glabella. Those forms have a transversely wider occipital ring and slightly narrower fixigenae than the clavate forms. They are further distinguished from almost all of the specimens from Wadi Zerqa Ma'in by transversely wider palpebral lobes and more strongly projecting anterior wings. It is noteworthy that the sagittal breadth of the preglabellar field varies considerably within the Siberian specimens but does not show a relationship to the glabellar shape. Two incomplete specimens from Wadi Zerqa Ma'in show a broader (or shorter) frontal lobe of the glabella. There is little doubt, however, that these specimens belong to the same species. Nevertheless, they illustrate the difficulties in portraying the morphological characteristics.

Because of the absence of precise stratigraphical and locality information in Chernysheva's earlier publications on Enixus (as Schistocephalus; Chernysheva 1956, 1961), it is impossible to assess whether the recognizable morphological differences between specimens are probably due to taxonomic or preservational differences or if the material indeed belongs to a single species with a large and unusual type of variation. In any case, subsequent studies dealing with Siberian specimens of Enixus antiquus do not illustrate specimens that accurately match the Wadi Zerqa Ma'in type morphology (e.g., Egorova et al. 1976).

In addition, an apparently clearly distinguishing character between the specimens from Jordan and those from Siberia was already described by Rushton and Powell (1998, p. 143) but not taken into consideration: it is the absence of a distinct occipital node as seen in the Siberian specimens. The cranidia from Wadi Zerqa Ma' in have at best a tiny swelling on the occipital ring.

Gozalo et al. (2007, fig. 4F-4H) figured two incomplete cranidia from the Valdore section of the Cantabrian Mountains as Palaeolenus sp. These specimens apparently represent a species best placed under Enixus and appear to resemble an internal mould with a fairly low convexity found at Wadi Zerqa Ma' in (Textfig. 19.7, 19.10). However, the wider glabella (across L1) with a broad anterior border carrying terrace ridges only in the anterior half and other characters differentiate these specimens from the Jordanian material.

Family uncertain

Genus and species undeterminate 2

(Text-fig. 20)

MATERIAL: Singlefragment of a pygidium, FG-602005, from the Wadi Uhaymir locality, Jordan.

DESCRIPTION AND DISCUSSION: The specimen is a fragment of a comparatively large pygidium having a more or less an incomplete rhachis with a quite unusual morphology. Preserved is the c. $6 \mathrm{~mm}$ long rhachis consisting of 8 rings in this specimen. These axial rings consist of a strongly convex, almost regularly transverse median section of c. 80 to $85 \%$ width of the entire axis and narrow lateral portions separated from the former by a change in convexity and somewhat irregularly wrinkled narrow furrows as well as slightly rearward deviation with respect to the median section. The long median sections of the axial rings are delimited from each other by moderately well developed furrows, which fade progressively backwards. The course and composition of these furrows are complicated by irregularly and obliquely directed wrinkles, which also become
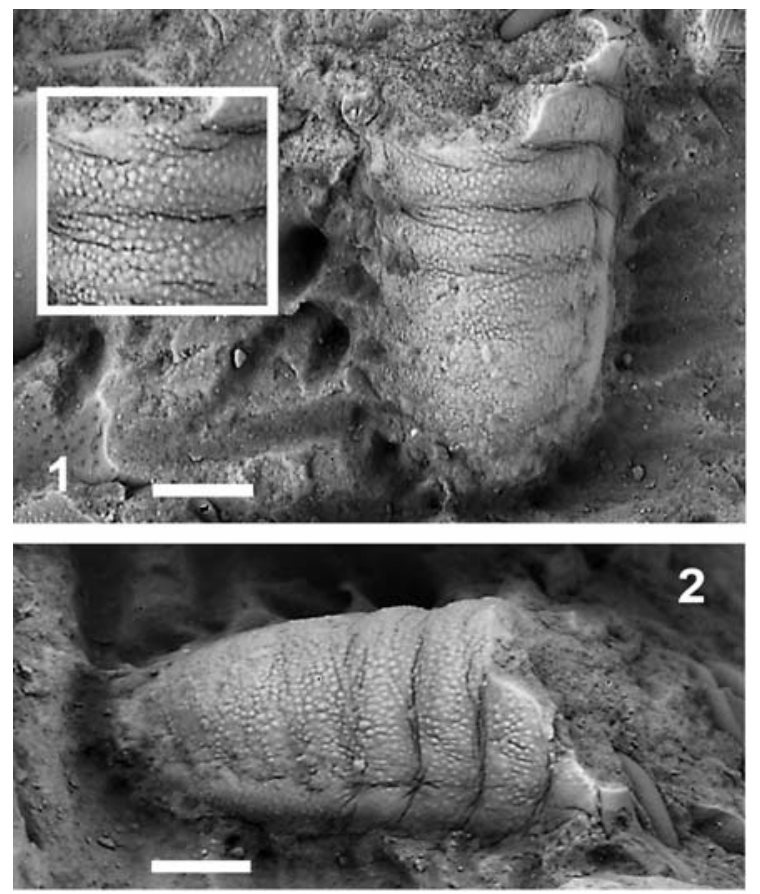

Text-fig. 20. Genus and species indeterminate 2; FG-602-005, fragment of pygidium, Wadi Uhaymir locality. Scale bar $1 \mathrm{~mm}$. 1, dorsal view, with insert of more stongly magnified surface; 2 , right lateral view 
less obvious backwardly. The lateral sulci appear to depict the sites where the dorsoventral musculature of the ventral appendages inserted. The surface of the axial rings is covered by fairly coarse granules of somewhat variable size, whereas the lateral portions of the axial rings tend to be partly smooth. The axis terminates with an imperfectly preserved axial piece with a semicircular to slightly crescentic shape in dorsal view.

Other parts of the exoskeleton unknown.

The segmentation, the wrinkled arrangment of the furrows and the coarse granulation of the surface are not known in any other trilobite species from this stratigraphical interval of West Gondwana.

\section{Acknowledgements}

The material for this study was collected during the course of several field campaigns by O.E. and his Cambrian working group, funded by a research grant from the Deutsche Forschungsgemeinschaft (DFG) to O.E. Collection was also made possible by the generous support from the Natural Resources Authority (NRA) of Jordan. Furthermore, O.E. is grateful for joint field work with Rafie Shinaq (Yarmouk University Irbid, Jordan), Klaus Bandel (Hamburg University), Thomas Wotte (Münster University) and Thomas Biener (now Ludwigsfelde, Germany). Comparative trilobite specimens from the Negev and Jordan were collected by G.G. during field research campaigns with E. Landing, New York State Museum, Albany, NY., USA. Due to various circumstances, this study developed into a long term project supported technically by several institutions.

Particular thanks are due to P. Ahlberg (Lund) and A. Żylińska (Warsaw) for extremely thorough reviews of the manuscript and important suggestions for modifications. In addition, we are indebted to Anthony Vincent, Aberdeen, for important observations and for sharing his unpublished field data from the Moroccan Anti-Atlas.

\section{REFERENCES}

Álvaro, J.J., Elicki, O., Geyer, G., Rushton, A.W.A. and Shergold, J.H. 2003. Palaeogeographic control on the Cambrian trilobite immigration and evolutionary pattern reported in the western Gondwana margin. Palaeogeography, Palaeoclimatology, Palaeoecology, 195, 5-35.

Amireh, B.S., Schneider, W. and Abed, A.M. 1994. Evolving fluvial-transitional-marine deposition through the Cambrian sequence of Jordan. Sedimentary Geology, 89, 6590.

Amireh, B.S., Schneider, W. and Abed, A.M. 2001. Fluvialshallow marine-glaciofluvial depositional environments of the Ordovician system in Jordan. Journal of Asian Earth Sciences, 5, 1-17.

Amireh, B.S., Ameireh, M.N. and Abed, A.M. 2008. Tectonosedimentary evolution of the Umm Ghaddah Formation (late Ediacaran-early Cambrian) in Jordan. Journal of Asian Earth Sciences, 33, 194-218.

Andrews, I.J. 1991. Palaeozoic lithostratigraphy in the subsurface of Jordan. Subsurface Geology Bulletin 2, 1-75. Natural Resources Authority, Geology Directorate, Subsurface Geology Division; Amman.

Bednarczyk, W. 1970. Trilobites Fauna [sic] of the Lower Paradoxides oelandicus Stage from the Brzechów Area in the Western Part of the Świętokrzyskie Mts. Bulletin de l'Académie Polonaise des Sciences, Série des Sciences Géologiques et Géographiques, 18, 29-35.

Bender, F. 1968a. Über das Alter und die Entstehungsgeschichte des Jordangrabens am Beispiel seines Südabschnittes (Wadi Araba, Jordanien). Geologisches Jahrbuch, 86, 177-196.

Bender, F. 1968b. Geologie von Jordanien, pp. 1-230. Borntraeger; Stuttgart.

Best, J.A., Barazangi, M., Al-Saad, D., Sawaf, T. and Gebran, A. 1993. Continental margin evolution of the northern Arabian platform in Syria. AAPG Bulletin, 77, 173-193.

Blanckenhorn, M. 1910. Neues zur Geologie Palästinas und des ägyptischen Niltals. Zeitschrift der Deutschen Geologischen Gesellschaft, 62, 405-461.

Blanckenhorn, M. 1912. Naturwissenschaftliche Studien am Toten Meer und im Jordantal. Bericht über eine im Jahre 1908 (im Auftrag S. M. des Sultans der Türkei Abdul Hamid II. und mit Unterstützung der Berliner JagorStiftung) unternommene Forschungsreise in Palästina. pp. 1-478, R. Friedländer \& Sohn; Berlin.

Bornemann, J.G. 1891. Die Versteinerungen des Cambrischen Schichtensystems der Insel Sardinien, etc. Abt. 2. Nova Acta der Kaiserlichen Leopold.-Carol. Deutschen Akademie der Naturforscher, 56 (3), 1-101 [427-528]

Chang W.T., Repina, L.N. and Geyer, G. 1997. Suborder Redlichiina Richter, 1932. In: H.B. Whittington, B.D.E. Chaterton, S.E. Speyer et mult. al. (Ed.), Treatise on Invertebrate Paleontology, Part O, Arthropoda 1, Trilobita, Revised, Volume 1: Introduction, Order Agnostida, Order Redlichiida, p. 429-470. The Geological Society of America, Boulder, CO, The University of Kansas Press, Lawrence, KS.

Chernysheva, N.E. 1956. Rod Schistocephalus Lermontova (in coll.). In: L.D. Kiparisova, B.P. Markovskiy and G.P. Radchenko (Eds), Materialy po paleontologii. Novie semeystva i rody. Trudy VSEGEI, Novaya Seriya, Paleontologiya, 12, 147-150.

Chernysheva, N. E. (Ed.) 1971. Amginskiy yarus Altae-Sayanskoj oblasti. Trudy Sibirskogo nauchno-issled. institut geologii, geofiziki i mineral'nogo syr'ya, Serya paleon- 
tologiya i stratigrafiya, III, pp. 1-267, ZapadnoSibirskoe nizhnoe izdatelstvo; Novosibirsk.

Cooper, G.A. 1976. Lower Cambrian brachiopods from the Rift Valley (Israel and Jordan). Journal of Paleontology, 50, 269-289.

Creplin, F.H.C. 1829. Novae observationes de entozois. 134 pp. Berlin,

Dean, W.T. 2005. Trilobites from Çal Tepe Formation (Cambrian), near Seydişehir, Central Taurides, Southwestern Turkey. Turkish Journal of Earth Sciences, 14, 1-71.

Dean, W.T. and Özgül, N. 1994. Cambrian rocks and faunas, Hüdai area, Taurus Mountains, southwestern Turkey. Bulletin de l'Institut Royal des Sciences Naturelles de Belgique, Sciences de la Terre, 64, 5-20.

Dienemann, W. 1915. Älteres Paläozoikum von Südsyrien und Westarabien. Centralblatt für Mineralogie, Geologie und Paläontologie, 16, 23-26.

Dies Álvarez, M.E. 2004. Bioestratigrafía y Paleoecología de la Formación Valdemiedes (límite Cámbrico InferiorMedio) en las Cadenas Ibéricas. Unpublished Ph.D. thesis, Universidad de Zaragoza, pp. 1-147.

Dies, M.E., Gozalo, R. and Liñán, E. 1999. Presencia de Kingaspis campbelli (King 1923) (Trilobita en el Bilbiliense (Cámbrico Inferior) de Murero (Zaragoza). Temas Geológico-Mineros ITGE, 26, 283-286.

Dies, M.E., Gozalo, R. and Liñán, E. 2004. Zonación del Límite Bilbiliense-Leoniense (Formación Valdemiedes, Cámbrico Inferior-Medio) en las Cadenas Ibéricas. GeoTema, 6, 283-286.

Dies Álvarez, M.E., Liñán, E. and Gozalo, R. 2007. The Cambrian genus Onaraspis Öpik, 1968 (Trilobita), in Spain. Memoirs of the Association of Australasian Palaeontologists, 34, 419-429.

Drygant, D. and Konstantinenko, L. 2001. A new trilobite genus from the Cambrian of the Carpathian Foredeep. $\mathrm{Pa}$ leontological Collection, 33, 28-31. [In Ukrainian]

Egorova, L.I., Rozanov, A.Yu., Savitskiy, V.E., Chernysheva, N.E. and Shabanov, Yu.Ya. 1976. Elanka and Kuonamka facies stratotypes of the lower boundary of the Middle Cambrian in Siberia. Trudy Sibirskogo nauchno-issled. institut geologii, geofiziki i mineral'nogo syr'ya, 211, 1-168. Nedra; Moscow. [In Russian]

Elicki, O. 2007. Facies development during late Early-Middle Cambrian (Tayan Member, Burj Formation) transgression in the Dead Sea Rift valley, Jordan. Carnets de Géologie, Article 2007/07, 1-20.

Elicki, O. 2011. First skeletal microfauna from the Cambrian Series 3 of the Jordan Rift Valley (Middle East). CambroOrdovician Studies IV. Memoirs of the Association of Australasian Palaeontologists, 42, 153-173.

Elicki, O. and Geyer, G. 2010. The faunal province of the southern margin of the Rheic Ocean. Cambrian biostratigraphy. In: U. Linnemann and R.L. Romer (Eds),
Pre-Mesozoic Geology of Saxo-Thuringia - From the Cadomian Active Margin to the Variscan Orogen, 103114. Schweizerbart; Stuttgart.

Elicki, O. and Pillola, G.L. 2004. Cambrian microfauna and palaeoecology of the Campo Pisano Formation at Gutturu Pala (Iglesiente, SW Sardinia, Italy). Bolletino della Società Paleontologica Italiana, 43, 383-401.

Elicki, O., Schneider, J. and Shinaq, R. 2002. Prominent facies from the Lower/Middle Cambrian of the Dead Sea area (Jordan) and their palaeogeographical significance. Bulletin de la Société Géologique de France, 173, 547552.

Elicki, O. and Shinaq, R. 2000. Kambrische Lagunen-Karbonate vom südlichen Toten Meer (Wadi Tayan, Jordanien). Paläontologie, Stratigraphie Fazies - psf 8. Freiberger Forschungshefte, C 490, 51-66.

Fletcher, T.P. 2003. Ovatoryctocara granulata: the key to a global Cambrian stage boundary and the correlation of the olenellid, redlichiid and paradoxidid realms. Special $\mathrm{Pa}$ pers in Palaeontology, 70, 73-102.

Fletcher, T.P. 2006. Bedrock geology of the Cape St. Mary's Peninsula, southwest Avalon Peninsula, Newfoundland. Government of Newfoundland and Labrador, Geological Survey, Department of Natural Resources, St. John's, Report, 06-02, 1-117.

Frech, F. 1897. Lethaea geognostica oder Beschreibung und Abbildung der für die Gebirgs-Formationen bezeichendsten Versteinerungen. Band 1, Lethaea palaeozoica. Textband II, Lieferung 1 (1897), pp. 1-256. Schweizerbart; Stuttgart.

García-Bellido, D.C., Dies Álvarez, M.E.,Gámez Vintaned, J.A., Liñán, E. and Gozalo, R. 2011. First report of Crumillospongia (Demospongea) from the Cambrian of Europe (Murero biota, Spain). Bulletin of Geosciences, 86, 641-650.

Geyer, G. 1988. Agnostida aus dem höheren Unterkambrium und dem Mittelkambrium von Marokko. Teil 2: Eodiscina. Neues Jahrbuch für Geologie und Paläontologie, Abhandlungen, 177, 93-133.

Geyer, G. 1990a. Revised Lower to lower Middle Cambrian biostratigraphy of Morocco. Newsletters on Stratigraphy, 22, 53-70.

Geyer, G. 1990b. Die marokkanischen Ellipsocephalidae (Trilobita: Redlichiida). Beringeria, 3, 1-363.

Geyer, G. 1998. Intercontinental, trilobite-based correlation of the Moroccan early Middle Cambrian. Canadian Journal of Earth Sciences, 35, 374-401.

Geyer, G. 2005. The base of a revised Middle Cambrian: are suitable concepts for a series boundary in reach? Geosciences Journal, 9, 81-99.

Geyer, G. and Landing, E. 2000. The Cambrian in Israel and Jordan - the feather edge of the Mediterranean Realm. In: G.F. Aceñolaza and S. Peralta (Eds), Cambrian from the 
southern edge. Miscelánea, San Miguel de Tucumán, 6, 98-101.

Geyer, G. and Landing, E. 2001. Middle Cambrian of Avalonian Massachusetts: stratigraphy and correlation of the Braintree trilobites. Journal of Paleontology, 75, 116-135.

Geyer, G. and Landing, E. 2004. A unified Lower-Middle Cambrian chronostratigraphy for West Gondwana. Acta Geologica Polonica, 54, 179-218.

Geyer, G. and Landing, E. 2006. Ediacaran-Cambrian depositional environments and stratigraphy of the western Atlas regions. In: G. Geyer and E. Landing (Eds), Morocco 2006 - Ediacaran-Cambrian depositional environments and stratigraphy of the western Atlas regions. UCL Maghreb Petroleum Research Group, Infracambrian/Early Palaeozic Field Guide Series 1 and Beringeria Special Issue, 6, 47-120.

Geyer, G. and Peel, J.S. 2011. The Henson Gletscher Formation, North Greenland, and its bearing on the global Cambrian Series 2-Series 3 boundary. Bulletin of Geosciences, 86, 465-543.

Gil Cid, M.D., García Rincon, J.M. and Mora Núñez, M. 2011. El Cámbrico inferior de Castilla La Mancha (España): Actualización y coordinación de los yacimientos con trilobites. Dugesiana, 18, 45-64.

Gil Cid, M.D. and Jago, J.B. 1989. New data on the Lower Cambrian trilobites of Cortijos de Malagón (Spain). Estudios geológicos, 45, 91-99.

Gon, S. III. Bathynotidae. In: A Guide to the Orders of Trilobites, http://www.trilobites.info/bathynotidae.htm (last revision 16 March 2007).

Gozalo, R. and Liñán, E. 1997. Revision of the genus Onaraspis Öpik 1968 and its biostratigraphic and biogeographic significance. In: Second International Trilobite Conference, Brock University, St. Catharine's, Ontario, August 22-25, Abstract with Program, 24-25.

Gozalo, R., Liñán, E., Dies Álvarez, M.E., Gámez Vintaned, J.A., and Mayoral, E. 2007. The Lower-Middle Cambrian boundary in the Mediterranean subprovince. In: U. Linnemann, R.D. Nance, P. Kraft and G. Zulauf (Eds), The Evolution of the Rheic Ocean: From Avalonian-Cadomian active margin to Alleghenian-Variscan collision. Geological Society of America Special Paper, 423, 359-373.

Gozalo, R., Liñán, E., Gámez Vintaned, J.A., Dies Álvarez, M.E., Chirivella Martorell, J.B., Zamora, S., Esteve, J. and Mayoral, E. 2008. The Cambrian of the Cadenas Ibéricas (NE Spain) and its trilobites. In: I. Rabano, R. Gozalo and D. García-Bellido (Eds), Advances in trilobite research. Cuadernos del Museo Geominero, 9, 137-151.

Hall, J. 1860. Note upon the trilobites of the shales of the Hudson River Group in the Town of Georgia, Vermont. University of the State of New York, Annual Report of the N. Y. State Cabinet of Natural History, 13, 113-119.

Harrington, H.J., Henningsmoen, G., Moore, R.C. and
Poulsen, C. 1959. Redlichiacea, Ellipsocephalacea. In: R.J. Moore (Ed.), Treatise on Invertebrate Paleontology, Part O, Arthropoda 1, pp. O198-O212. Geological Society of America and University of Kansas Press; Lawrence, KS.

Hofmann, R., Mángano, G., Elicki, O. and Shinaq, R. 2012. Paleoecologic and biostratigraphic significance of trace fossils from Middle Cambrian shallow- to marginal-marine environments of Jordan. Journal of Paleontology, 86, 931-955.

Hupé, P. 1953a. Contribution à l'étude du Cambrien inférieur et du Précambrien III de l'Anti-Atlas marocain. Notes et Mémoirs de la Service géologique du Maroc, 103, 1-402 [“1952"]

Hupé, P. 1953b. Classification des trilobites. Annales de Paléontologie, 39, 61-168 (1-110).

Husseini, M.I. 1989. Tectonic and depositional model of Late Precambrian-Cambrian Arabian and adjoining plates. AAPG Bulletin, 73, 1117-1131.

Jell, P.A. and Adrain, J.M. 2003. Available generic names for trilobites. Memoirs of the Queensland Museum, 48, 331553.

Karcz, I. and Key, C.A. 1966. Note on the pre-Paleozoic morphology of the basement in the Timna area (southern Israel). Israel Journal of Earth Sciences, 15, 47-56.

Khalfin, L.L. (Ed.) 1960. Biostratigraphy of the Paleozoic in the Sayan-Altai Mountain region. Vol. 1. Lower Paleozoic. Trudy sib. nauchno-issled. inst. geol. geofiz. miner. syr'ya SNIIGGiMS), 1 (19), 1-497. Novosibirsk. [In Russian]

King, W.B.R. 1923. Cambrian Fossils from the Dead Sea. Geological Magazine, 60, 507-514.

Kobayashi, T. 1935. The Cambro-Ordovician Formations and Faunas of South Chosen. Paleontology. Part III. Cambrian Faunas of South Chosen with A Special Study on the Cambrian Trilobite Genera and Families. Journal of the Faculty of Science, Imperial University, Tokyo, Section II, Geology, Mineralogy, Geography, Seismology, IV (2), 49-344.

Korovnikov, I.V. 2001. Lower and Middle Cambrian Boundary and trilobites from northeast Siberian Platform. In: Peng Shanchi, L.E. Babcock and Zhu Maoyan (Eds), The Cambrian System of South China. Palaeoworld, 13, 270 275.

Landing, E., Geyer, G. and Heldmaier, W. 2006. Distinguishing eustatic and epeirogenic controls on Lower-Middle Cambrian boundary successions in West Gondwana (Morocco and Iberia). Sedimentology, 53, 899-918.

Lazarenko, N.P. 1962. New Lower Cambrian trilobites from the Soviet Arctic. Sbornik statej paleont. biostrat. Inst. geol. Arktiki, NIIGA, 29, 29-78. [In Russian]

Lermontova, E.V. 1940. VI Tip - Arthropoda. In: A. Vologdin (Ed.), Atlas of the leading forms of fossil faunas of the USSR, 1, Cambrian. Gosudarstvennoe izdat. geol. lit., p. 
112-157. Gosgeoltekhizdat; Moskau, Leningrad. [In Russian]

Lin, T.R. and Peng, S.C. 2004. New material of Palaeolenus (trilobite, Cambrian) from the eastern Yangtze Gorge area, Western Hubei. Acta Palaeontologica Sinica, 43, 32-42.

Liñán, E. and Gozalo, R. 1986. Trilobites del Cámbrico inferior y medio de Murero (Cordillera Ibérica). Memorias del Museo Paleontológico, Universidad de Zaragoza, 2, 1104.

Liñán, E., Gozalo, R., Palacios, T., Gámez Vintaned, J.A., Ugidos, J.M. and Mayoral, E. 2002. Cambrian. In: W. Gibbons and T. Moreno (Eds), The Geology of Spain, p. 1729. The Geological Society; London.

Liñán, E., Dies, M.E. and Gozalo, R. 2003. A review of the genus Kingaspis (Trilobita, Lower Cambrian) from Spain and its biostratigraphical consequences for the correlation in the Mediterranean subprovince. Revista Española de Paleontología, 18, 3-14.

Liñan, E., Perejon, A., Gozalo, R., Moreno Eiris, E. and Oliveira, T.J. 2004. The Cambrian system in Iberia. pp. 163. Instituto Geológico y Mineiro de España; Madrid.

Liñán, E., Gozalo, R., Dies Álvarez, M.E., Gámez Vintaned, J.A., Mayoral, E., Chirivella Martorell, J.B., Esteve, J., Zamora, S., Zhuravlev, A.Yu. and Andrés, J.A. 2008. Lower and Middle Cambrian trilobites of selected localities in Cadenas Ibéricas (NE Spain). Fourth International Trilobite Conference Trilo 08, Toledo, Spain, 2008, PostConference Field Trip, pp. 1-52. Universidad de Zaragoza; Zaragoza.

Lochman-Balk, C. 1959. Suborder Bathynotida. In: R.J. Moore (Ed.), Treatise on Invertebrate Paleontology, Part O, Arthropoda 1, p. O216-O217. Geological Society of America and University of Kansas Press; Lawrence, KS.

Luo, H.L., Li, Y., Hu, S.X., et al. 2007. On the genus Megapalaeolenus Chang, 1966. Acta Palaeontologica Sinica, 46, 314-326. [In Chinese]

Makhlouf, I.M. 2003. Braided river model and associated facies of lower Cambrian age in South Jordan. Africa Geoscience Reviews, 10, 289-300.

Makhlouf, I.M. and Abed, A.M. 1991. Depositional facies and environments in the Umm Ishrin Sandstone Formation, Dear Sea area, Jordan. Sedimentary Geology, 71, 177-187.

Mángano, M.G., Buatois, L.A., Hofmann, R., Elicki, O. and Shinaq, R. (in press). Exploring the aftermath of the Cambrian explosion: The evolutionary significance of marginal- to shallow-marine ichnofaunas of Jordan. Palaeogeography, Palaeoclimatology, Palaeoecology.

Mángano, G., Hofmann, R., Elicki, O. and Shinaq, R. 2007. Paleoecologic and paleoenvironmental controls of trace fossils from a Lower to Middle Cambrian tide-dominated delta, Hanneh Member, Burj Formation, Southern Death Sea, Jordan. In: J.A. MacEchern, M.K. Gingras, K.L. Bann and S.G. Pemberton (Eds), Ichnological applications to sedimentological and sequence stratigraphic problems. SEPM Research Conference, p. 101. Price, UT.

Mansuy, H. 1912. IIe Partie. Paléontologie. In: Deprat, J. and Mansuy, H., Etude géologique du Yun-Nan oriental. Mémoir de la Service géologique d'Indochine, I (II), 1-146.

Matthew, G.F. 1887a. Illustrations of the fauna of the St. John Group. No. IV. On the smaller-eyed trilobites of Division I, with a few remarks on the species of the higher divisions of the group. Canadian Record of Science 2, 357-363.

Matthew, G.F. 1887b. Protolenus - a new genus of Cambrian trilobites. Bulletin of the Natural History Society of New Brunswick, 10, 34-37.

Matthew, G.F. 1895. The Protolenus fauna. Transactions of the New York Academy of Science, 14 (for 1894-1895), 101153.

Naimark, E., Shabanov, Y. and Korovnikov, I. 2011. Cambrian trilobite Ovatoryctocara Tchernysheva, 1962 from Siberia. Bulletin of Geosciences, 86, 405-422.

Neltner, L. 1938. Etudes géologiques dans le Sud marocain (Haut Atlas et Anti-Atlas). Notes et Mémoirs de la Service des Mines et Carte géologique du Maroc, 42, 1-298.

Özdikmen, H. 2009. Nomenclatural changes for twenty trilobites genera. Munis Entomology \& Zoology, 4, 155-171.

Öpik, A.A. 1968. The Ordian Stage of the Cambrian and its Australian Metadoxididae. Bureau of Mineral Resources of Australia, Bulletin, 92, 133-166.

Öpik, A.A. 1975. Cymbric Vale Fauna of New South Wales and Early Cambrian Biostratigraphy. Bulletin of the Bureau of Mineral Resources of Australia, 159, I-IV, 1-78.

Palmer, A.R. 1968. Cambrian trilobites of east-central Alaska. U.S. Geological Survey, Professional Paper, 559-B, 1115.

Parnes, A. 1971. Late Lower Cambrian trilobites from the Timna Area and Har 'Amram (Southern Negev, Israel). Israel Journal of Earth Sciences, 20, 179-205.

Peng, J., Zhao, Y.L., Yuan, J.L., Yao, L. and Yang, H. 2009. Bathynotus: A key trilobite taxon for global stratigraphic boundary correlation between Cambrian Series 2 and Cambrian Series 3. Progress in Natural Science, 19, 99105.

Pflüger, F. 1990. Flash flood conglomerates and Cambrian transgression in Petra/Jordan. Diplomarbeit, Geowissenschaftliche Fakultät der Eberhard-Karls-Universität Tübingen, 164 pp. [unpublished]

Picard, L. 1942. New Cambrian fossils and Paleozoic problematica from the Dead Sea and Arabia. Bulletin of the Department of Geology, Hebrew University, 4 (1), 1-18.

Pocock, K.J. 1970. The Emuellidae, a new family of trilobites from the Lower Cambrian of South Australia. Paleontology, 13, 522-562.

Poulsen, C. 1927. The Cambriaan, Ozarkian, and Canadin faunas of northwestern Grenland. Meddelelser om Grønland, 70, 233-343. 
Powell, J.H. 1989. Stratigraphy and sedimentation of the Phanerozoic rocks in Central and South Jordan, Part A: Ram and Khreim Groups. Natural Resources Authority, Geology Directorate, Geological Mapping Division, Bulletin, 11, 1-72.

Richter, R. and Richter, E. 1941. Das Kambrium am Toten Meer und die älteste Tethys. Abhandlungen der Senckenbergischen Naturforschenden Gesellschaft, 460, 1-50.

Richter, R. and Richter, E. 1948. Zur Frage des Unter-Kambriums in Nordost-Spanien. Senckenbergiana, 29, 23 39.

Rushton, A.W.A. and Powell, J.H. 1998. A review of the stratigraphy and trilobite faunas from the Cambrian Burj Formation in Jordan. Bulletin of the British Museum (Natural History), Geology, 54, 131-146.

Schneider, W., Amireh, B.S. and Abed, A.M. 2007. Sequence analysis of the Early Paleozoic sedimentary systems of Jordan. Zeitschrift der deutschen Gesellschaft für Geowissenschaften, 158, 225-247.

Sdzuy, K. 1961. Das Kambrium Spaniens. Teil II: Trilobiten. 1. Abschnitt. Akademie der Wissenschaften und Literatur, Mainz, Abhandlungen der Mathematisch-Naturwissenschaftlichen Klasse, 1961 (7), 499-594 (217-312).

Sdzuy, K. 1978. The Precambrian-Cambrian boundary beds in Morocco (Preliminary Report). Geological Magazine, 115, 83-94.

Sdzuy, K. 1995. Acerca del conocimiento actual del Sistema Cámbrico y del límite Cámbrico Inferior-Cámbrico Medio. In: J.A. Gámez Vintaned and E. Liñán (Eds), Memorias de las IV Jornadas Aragonesas de Paleontología: "La expansión de la vida en el Cámbrico", Libro homenaje al Prof. Klaus Sdzuy, 253-263, Institución "Fernando el Católico", Zaragoza.

Sdzuy, K., Liñán, E. and Gozalo, R. 1999. The Leonian Stage (early Middle Cambrian): a unit for Cambrian correlation in the Mediterranean subprovince. Geological Magazine, 136, 39-48.

Segev, A. 1984. Lithostratigraphy and palaeogeography of the marine Cambrian sequence in southern Israel and southwestern Jordan. Israel Journal of Earth Sciences, 33, 2633.

Seilacher, A. 1990. Paleozoic trace fossils. In: R. Said (Ed.), The Geology of Egypt, 1565-1581. Balkema; Rotterdam.

Selley, R.C. 1972. Diagnosis of marine and non-marine environment from Cambro-Ordovician sandstones of Jordan. Journal of the Geological Society, London, 128, 135150.

Sepkoski, J.J. 2002. A compendium of fossil marine animal genera. Bulletins of American Paleontology, 363, 1-550.

Shabanov, Yu.Ya., Korovnikov, I.V., Pereladov, V.S. and Fefelov, A.F. 2008. Excursion 1. The traditional LowerMiddle Cambrian boundary in the Kuonamka Formation of the Molodo River section (the southeastern slope of the
Olenek Uplift of the Siberian Platform) proposed as a candidate for GSSP of the lower boundary of the Middle Cambrian and its basal (Molodian) stage, defined by the FAD of Ovatoryctocara granulata. In: The Cambrian System of the Siberian Platform. Part 2: North-East of the Siberian Platform. XIII International Field Conference of the Cambrian Stage Subdivision Working Group, Yakutia, Russia, July 20 - August 1, 2008, 8-59, PIN, RAS; Moscow, Novosibirsk.

Sharland, P.R., Archer, R., Casey, D.M., Davies, R.B., Hall, S.H., Heward, A.P., Horbury, A.D. and Simmons, M.D. 2001. Arabian Plate Sequence Stratigraphy. GeoArabia special publication, 2, 1-371. Oriental Press; Manama, Bahrain.

Shinaq, R. and Bandel, K. 1992. Microfacies of Cambrian limestones in Jordan. Facies, 27, 52-57.

Shinaq, R. and Elicki, O. 2007. The Cambrian sedimentary succession from the Wadi Zerqa Ma'in (northeastern Dead Sea area, Jordan): lithology and fossil content. Neues Jahrbuch für Geologie und Paläontologie, 243, 255-271.

Webster, M. 2009. Systematic revision of the Cambrian trilobite Bathynotus Hall, 1860, with documentation of new occurrences in western Laurentia and implications for intercontinental biostratigraphic correlation. Memoirs of the Association of Australasian Palaeontologists, 37, 369406.

Weissbrod, T. 1981. The Paleozoic of Israel and adjacent countries (lithostratigraphic study). Ph.D. Thesis, Hebrew University, Jerusalem, pp. 1-276. [In Hebrew with English summary]

Westrop, S.R. and Landing, E. 2000. Lower Cambrian (Branchian) trilobites and biostratigraphy of the Hanford Brook Formation, southern New Brunswick. Journal of Paleontology, 74, 858-878.

Whittington, H.B. 1988. Hypostomes and ventral cephalic sutures in Cambrian trilobites. Palaeontology, 31, 577-609.

Whittington, H.B. 1997. Morphology of the exoskeleton. In: H.B. Whittington, B.D.E. Chatterton, S.E. Speyer et mult. al. (Ed.), Treatise on Invertebrate Paleontology, Part O, Arthropoda 1, Trilobita, Revised, Volume 1: Introduction, Order Agnostida, Order Redlichiida, p. 1-85, The Geological Society of America, Boulder, CO, The University of Kansas Press, Lawrence, KS.

Yuan Jinliang, Zhao Yuanlong, Wang Zongzhe, Zhou Zhen and Chen Xiaoyuan 1997. A preliminary study on Lower-Middle Cambrian boundary and trilobite fauna at Balang, Taijiang, Guizhou, South China. Acta Palaeontologica Sinica, 36, 494-514. [In Chinese with English abstract]

Yuan Jinliang, Zhao Yuanlong and Li Yue 2001. Biostratigraphy of oryctocephalid trilobites. Acta Palaeontologica Sinica, 40 (supplement), 143-156. 
Yuan Jin-liang, Zhao Yuang-long, Li Yue and Huang Youzhuang 2002. Trilobite fauna of the Kaili Formation (uppermost Lower Cambrian-lower Middle Cambrian) from southeastern Guizhou, South China, pp. 1-422. Earth, Shanghai Scientific and Technical Publisher; Shanghai. [In Chinese with English summary]

Yuan Jinliang, Zhao Yuanlong, Peng Jin, Zhu Xuejian and Lin Jih-pai 2009. Cambrian trilobite Ovatoryctocara granulata Tchernysheva, 1962 and its biostratigraphic significance. Progress in Natural Science, 19, 213-221.

Zhang [Chang] Wentang 1966. On the classification of Redlichiacea, with description of new families and new genera. Acta Palaeontologica Sinica, 14, 135-184. [In Chinese and English]

Manuscript submitted: November $15^{\text {th }} 2011$ Revised version accepted: January $10^{\text {th }} 2013$
Zhang Wen-tang, Lu Yenhao, Zhu Zhaolin, Qian Yiyuan, Lin Huilin, Zhou Zhiyi, Zhang Senggui and Yuan Jinliang 1980. Cambrian Trilobite Faunas of Southwestern China. Palaeontologia Sinica, 159, New Series B, 16, pp. 1-497. Science Press; Beijing. [In Chinese with English summary]

Żylińska, A. and Masiak, M. 2007. Cambrian trilobites from Brzechów, Holy Cross Mountains (Poland) and their significance in stratigraphic correlation and biogeographic reconstructions. Geological Magazine, 144, 661-686.

Żylińska, A. and Szczepanik, Z. 2009. Trilobite and acritarch assemblages from the Lower-Middle Cambrian boundary interval in the Holy Cross Mountains (Poland). Acta Geologica Polonica, 59, 413-458 